\title{
IN THE PRESENCE OF GHOSTS
}

\section{Saskatchewan's Abandoned Landscape}

\author{
by Gina Rehbein
}

A thesis submitted to the Faculty of Graduate and Postdoctoral Affairs in partial fulfillment of the requirements for the degree of

Master of Architecture

in

Azrieli School of Architecture

Carleton University

Ottawa, Ontario

(C) 2019

Gina Rehbein 
Once the site of a bustling pioneer town, this location holds a history now invisible to its current condition. After years of despair brought on by the Great Depression, drought, and land restructuring, the town suffered and shrank until finally dissolving to it's current fate in 1980. This is one of many towns with a similar story in the southern parts of the province Saskatchewan. 
Abstract

In the late 1800's, highly optimistic government and railway promotional campaigns drew in thousands of immigrants to Canada's West, hopeful of the many promised benefits of prairie living. Rail lines quickly stretched in every direction and villages were born every ten miles along the way; what was once a landscape of windswept grasslands became rolling golden wheat fields and a myriad of little boomtowns. Within only a few short decades however, the growth quickly turned into despair; years of widespread drought, increased technology requiring fewer hands, and urban appeal convinced many to flee, leaving behind vacant homes and little hope for the few who stayed. Saskatchewan's rural depopulation continued as dependence on the numerous elevators and rail lines decreased, resulting in the removal or abandonment of these icons - once the hub of every prairie town. Within a timeline of roughly fifty years, Saskatchewan went from having fewer less than thirty settlements, to suddenly having several hundreds, and then to the death of nearly half of the newly established communities.

I was able to record these towns through reviewing a list of unincorporated communities in Saskatchewan, geographically locating them, then determining their current condition through satellite imagery and Google Street View. It was often unclear if these towns had any inhabitants left. The date of their incorporation revealed whether or not they were a hopeful colonial town blindsided by the hardships of the prairies. Every one of these failed towns was organized between 1900-1930. Nearly 400 of these communities in the province are now considered "ghost towns." 
A $660 \mathrm{~km}$ ribbon of patched blacktop known as Highway 13, however still ties together a series of these wholly or largely abandoned towns. Also known as Red Coat Trail - as it was the route the RCMP first used to overtake the prairies - Highway 13 became overshadowed by the Trans-Canada Highway, built just 50 km north in the early 1960's. Apart from the few towns that managed to keep their title, this long stretch of road has little resemblance to what it once was and with no likely intervention in sight, these fragments of our immigrant heritage will be all but invisible for the next generation.

l'd like to challenge this, by proposing that these sites can take a new ghostly form through visual story telling: bringing together their past, present, and possible future. Although there are a number of resources that tell of these towns, not one tells a combined story of their past and present in one place, nor has anyone been able to account for more than a couple dozen of them.

In the fall of 2018, I visited thirteen of these towns, located along the aforementioned Highway 13, to document their current state and get a feel for the atmosphere they hold. I was able to get 360-degree images of the streetscape as well as the interiors of the decaying buildings when accessible. I have catalogued these aspects into a database or exhibit of sorts - visiting themes of building typology, façade treatment, topography, statistics, and individual history. I have used these images in a way that presents the viewer with the current reality of the towns, but also reveals the past through dream-like representations of their individual stories. With this, I have achieved a unique record of these sites before they have vanished completely, one that may become a base for a continued collection of the many dissolving towns in the prairie landscape. 


\section{Acknowledgments}

To my advisor, Professor Stephen Fai, for his continued interest, knowledge, and genuine belief in this thesis,

To my parents for all of their support that has gotten me to this point,

To my friends who have encouraged me, filled these years with great memories, and created unbreakable relationships - special shout out to Kristi for always being by my side through the endless days and sleepless nights that both of these degrees have brought us, you made it enjoyable to practically live in the Architecture Building,

To Jules, for always being a great study buddy,

And finally, to my fiancé, Reed McKeague, for the endless love and support - you have done so much for me without giving it second thought nor expecting a thing in return, there hasn't been a day you haven't made better and I could never say this enough,

Thank you 


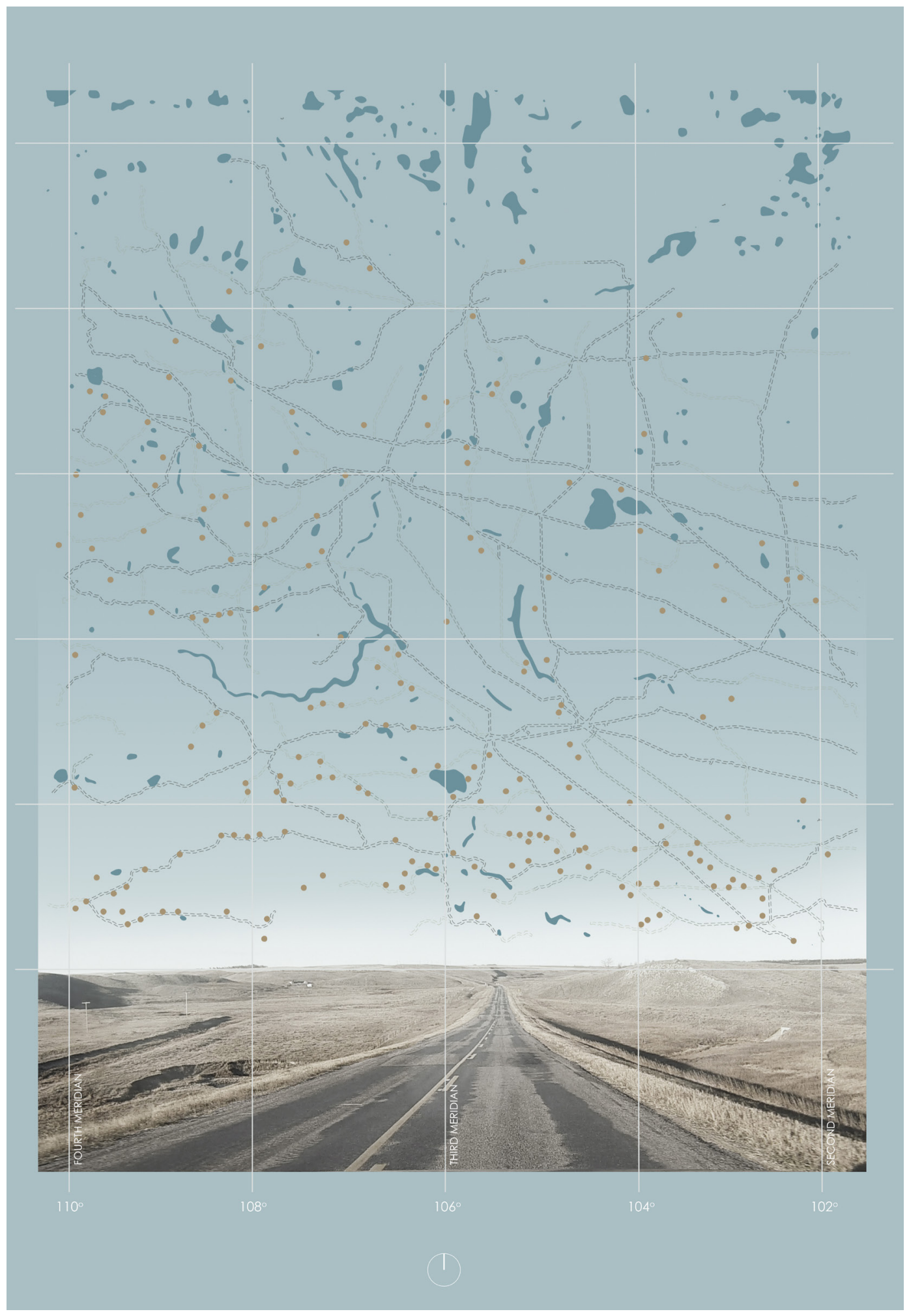

Fig 1.0 View of Saskatchewan's Highway 13 and known ghost towns 


\section{Contents}

$\begin{array}{lc}\text { Abstract } & \text { ii } \\ \text { Acknowledgements } & \text { v } \\ \text { Table of Contents } & \text { vil } \\ \text { List of Illustrations } & \text { ix }\end{array}$

$\begin{array}{ll}\text { Introduction } & 01 \\ 01 \text { Haunted Land } & 06 \\ \text { Town } & 07 \\ \text { Typology } & 09 \\ \text { Architecture } & 14 \\ 02 \text { History of a Pioneer Town } & 22 \\ \text { Settlement of the Prairies } & 23 \\ \text { Railway and Town Development } & 27 \\ \text { Not all is as Perceived } & 29 \\ \text { The Beginning of the End } & 32 \\ \text { 03 In a State of Dissolution } & 42 \\ \text { Dissolution of Towns } & 43 \\ \text { Current Conditions } & 45 \\ \text { Atmosphere } & 48 \\ \text { Vanishing History } & 50 \\ \text { Resolution } & 51\end{array}$


0413 Towns - Highway 13

Introduction

Ghost Town Template

Samples of Towns

Appendix 01

Highway 13 Experience

Appendix 02

93

Ghosted Ghost Towns

Conclusion 


\section{List of Illustrations}

Any figures unless otherwise noted are by author.

Fig 1.0 View of Saskatchewan's Highway 13

Fig 2.1 Map of Saskatchewan's Ghost Towns and Railways

Fig 2.2 Map of Saskatchewan's Ghost Towns and Railways

Fig 3.1 View inside abandoned home in Crichton, SK

Fig 3.2 View inside abandoned Co-op in Admiral, SK

Fig 4.0 View of derelict sidewalk in Admiral, SK.

Fig 5.0 Typical fake fronts. Quita Street, Robsart, SK.

Fig 6.0 Asphalt "Brick," siding material often seen in Saskatchewan's ghost towns. Khedive, SK.

Fig 7.0 Brick chimney. Wauchope, SK.

Fig 8.1 Promotional Poster for Prairie Settlement, 1909. Sourced from Graham Chandler's "Selling the Prairie Good Life."

Fig 8.2 Promotional Poster for Prairie Settlement, 1921. Sourced from Graham Chandler's "Selling the Prairie Good Life."

Fig 9.1 Division of Land into Townships. Sourced from Railway Lands Branch, "Supplement to Homestead Maps"

Fig 9.2 Division of Land into Sections.Sourced from Railway Lands Branch, "Supplement to 
Homestead Maps"

Fig 10.0 Abandoned grain elevator. Thunder Creek, Sk.

Fig 11.0 View of Admiral, Sk.

Fig 12.0 View of abandoned church at dusk. Froude, Sk.

Figures 13.1 - 17.8 are supplemented by images sourced from Glen Lundeen's "Images of Prairie Towns"

Fig 13.1 360 view with past image overlaid. Wauchope, Sk.

Fig 13.2 Location of Wauchope on Highway 13, Sk.

Fig 13.3 Street elevations, past and present conditions. Wauchope Sk.

Fig 13.4 Site plan of Wauchope

Fig 13.5 Cropped 360 view with past image overlaid. Wauchope, Sk.

Fig 13.6 Historical photo of Wauchope, Sk.

Fig 14.1 Location of Khedive along Highway 13, Sk.

Fig 14.2 Street elevation of Khedive, Sk.

Fig 14.3 Site Plan of Khedive, Sk.

Fig 15.1360 view with past image overlaid, Melaval, Sk.

Fig 15.2 Location of Melaval along Highway 13, Sk.

Fig 15.3 Street Elevations, Melaval, Sk.

Fig 15.4 Site Plan, Melaval, Sk.

Fig 15.5 Cropped 360 view with past image overlaid, Melaval, Sk.

Fig 16.1 360 view wit past image overlaid, Admiral, Sk.

Fig 16.2 Location of Admiral along Highway 13, Sk. 
Fig 16.3 Street Elevations, Admiral, Sk.

Fig 16.4 Site Plan, Admiral, Sk.

Fig 16.5 Cropped 360 view with past image overlaid, Admiral, Sk.

Fig 16.6 Cropped 360 view with past image overlaid, Admiral, Sk.

Fig 17.1 360 view with past image overlaid, Robsart, Sk.

Fig 17.2 Location of Robsart along Highway 13, Sk.

Fig 17.3 Street Elevations, Robsart, Sk.

Fig 17.4 Site Plan, Robsart, Sk.

Fig 17.5 Cropped 360 view with past image overlaid, Robsart, Sk.

Fig 17.6 Cropped 360 view with past image overlaid, Robsart, Sk.

Fig 17.7 Historical photo, Robsart, Sk.

Fig 17.8 Site map from 1915, Robsart, Sk.

Fig 18.0 Documented Towns along Saskatchewan's Highway 13

Fig 18.1 Minute 00 of Highway 13 Time-lapse.

Fig 18.2 Minute 02 of Highway 13 Time-lapse.

Fig 18.3 Minute 04 of Highway 13 Time-lapse.

Fig 18.4 Minute 06 of Highway 13 Time-lapse.

Fig 18.5 Minute 08 of Highway 13 Time-lapse.

Fig 18.6 Minute 10 of Highway 13 Time-lapse.

Fig 18.7 Minute 12 of Highway 13 Time-lapse. 
Fig 18.8 Minute 14 of Highway 13 Time-lapse.

Fig 18.9 Minute 16 of Highway 13 Time-lapse.

Fig 18.10 Minute 18 of Highway 13 Time-lapse.

Fig 18.11 Minute 20 of Highway 13 Time-lapse. 


\section{Introduction}

At the turn of the 19th century, Canada's west began a period of mass and rapid settlement. Thousands of immigrants from around the globe arrived with dreams of a better life in the land they had been told was fertile and abundant. Hundreds of communities sprouted in Saskatchewan during this process, with the anticipation that the population and economy would continue to grow and prosper. Unfortunately, their dreams turned into despair shortly after their arrival. Many factors played into this, and will be discussed thoroughly in Chapter 02, but will be briefly summarized here in order to give some context. As the entire province revolved around agriculture, every town depended on the success of the crops to keep their own businesses flourishing. Therefore, when they began to fail due to both natural and economical disasters, the towns quickly followed suit. The railway development that had lead to numerous new communities was discontinued, serving another blow, and people were forced to take the small amounts of grain they had to larger centres after hundreds of grain terminals shut down. Because of the small profit margin the farmers were acquiring, it became necessary to cultivate larger amounts of land, worsening the trend of rural depopulation. The majority of this all happened in a span of thirty years - although it still persists at a smaller scale to this day - resulting in the abandonment of now hundreds of small communities.

Saskatchewan's ghost towns hold a story unlike any other area - province, state, country, or otherwise. Other areas that contain a large num- 
ber of abandoned towns typically fall under the category of boom towns, with people rushing in to take advantage of gold, oil, or some other resource until it was depleted, then moving on to the next. Saskatchewan however is unique, as every single one of its towns followed a timeline of the same series of events. All came into existence at a particular time under the same circumstances, and soon after fell together as one. None of the towns were created to take advantage of a particular resource in that specific area, but rather to create the provincial wide fabric of a thriving agricultural community, and when that economy saw a nearly endless period of despair, the structure of that fabric was forced to shift, leaving behind hundreds of towns that supported it. The sheer number of them is incredulous; nearly 400 towns established within less than two decades, all having dissolved in the decades immediately following.

Having grown up in rural southern Saskatchewan, I am very familiar with the outcome of this situation and have always had a passion and interest in the prairie landscape. The seemingly never-ending fields are interrupted every so often by an abandoned building - many of them are markers of the town sites mentioned. I have located 350 of these abandoned towns in Saskatchewan, with another twenty-six unable to be located. Between any two communities that have managed to endure the years, there is one that has lost virtually everything. As rural depopulation is still occurring, this number continues to grow.

With further exploration of these towns, it is possible to examine what the traces they have left in their wake could mean in regards to their current and future existence - their 'ghost architecture,' so to speak. There are different understandings of what ghost architecture may be. Brian 
Mackay-Lyons has argued that it is a condition brought by building new architecture out of the traces of the past, "identifying the lines, residues, and marks of earlier buildings to anchor-or to root-his new works in this time-scarred landscape." [Ghost, 20]. In my exploration I would like to suggest that rather than a physical resurrection of the past, it is more of a sensory experience - a haunting. When faced with the quietness of the abandoned towns of Saskatchewan, there is little to distract the mind. It doesn't take long before the emotions and memories that were left behind, alongside the misplaced inanimate objects housed in the dilapidated buildings, become overwhelmingly present. Time begins to overlap, what once was and what still is presenting itself through the visible traces that were left on the geographical sites and residing in the minds of those who've experienced them. This feeling carries through the forgotten sites and into the rolling fields, haunting the prairie landscape. 


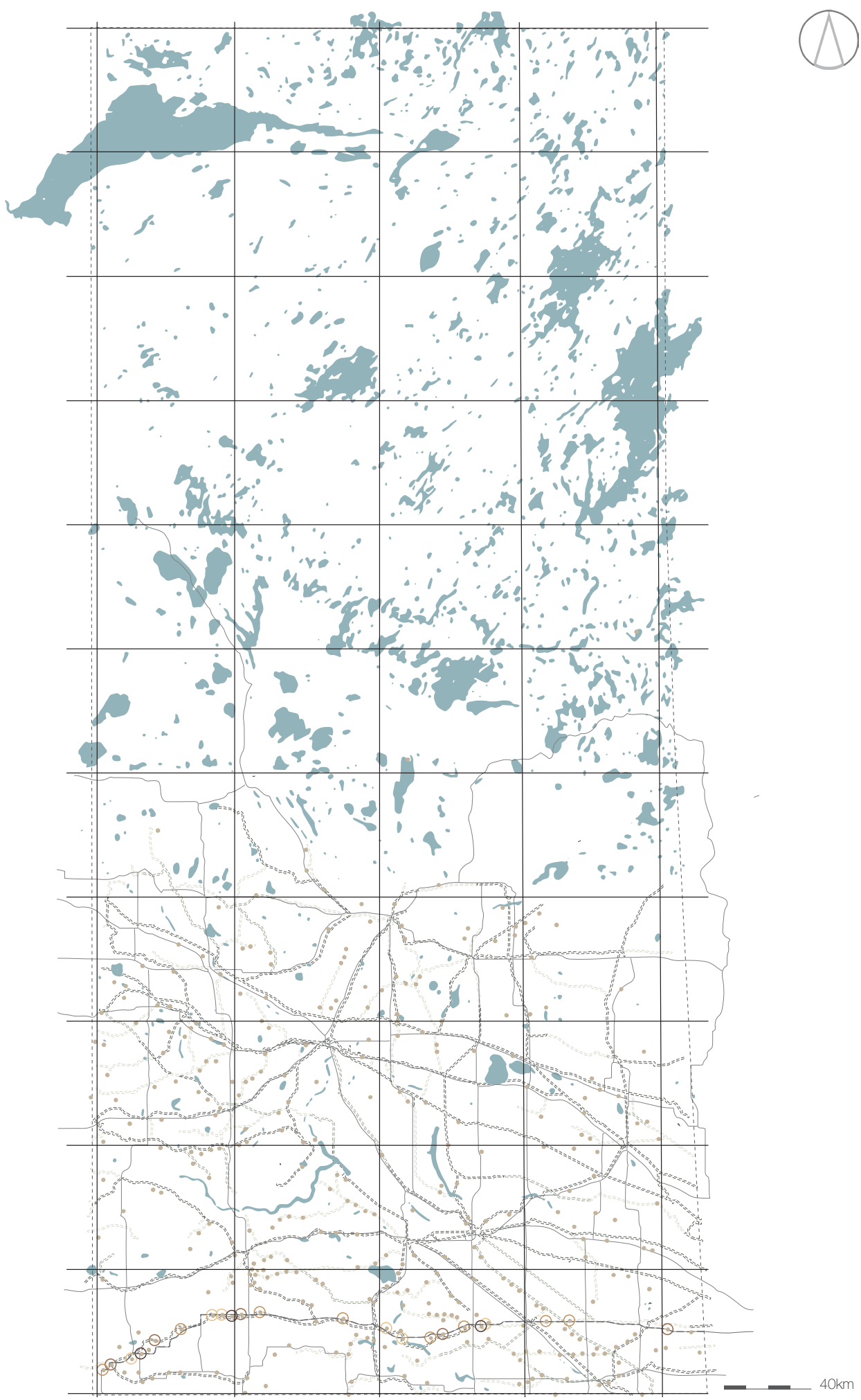

Fig 2.1 Map of Saskatchewan's Ghost Towns and Railways 


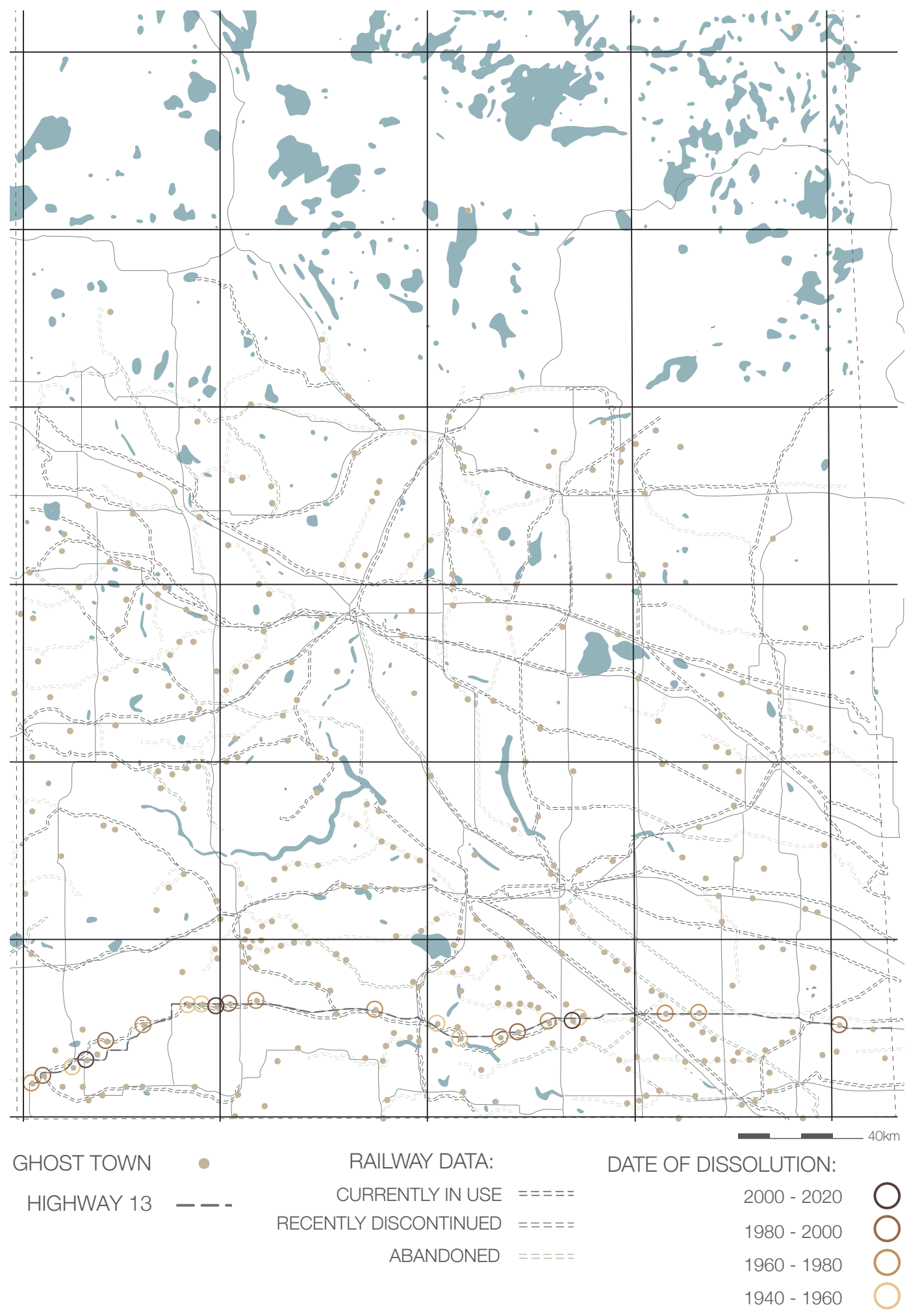

Fig 2.2 Map of Saskatchewan's Ghost Towns and Railways 


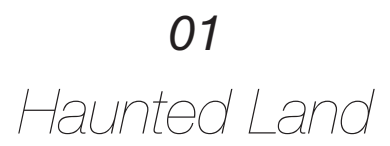

"For most of us, our first encounter with ghosts is through stories. ... Riveting, evocative, at times terrifying, these stories allow us to feel and breathe the atmosphere of the past. We can imagine ourselves there. Ghost stories are a form of travel-not across space to other countries and cultures - but across time, carrying our imagination with us."

[Ghost, 15] 


\section{Ghost Town}

In the streets of an abandoned Saskatchewan town site, you would not expect to find any living thing, other than in the depths of your imagination perhaps. Despite the death of its incorporation however, a ghost town has a presence. "Something forlorn haunts these remnants of prior eras..." [Spatial Recall, 195]. Upon thinking of the things that could be found in a ghost town, one might think of old buildings or ruins, imagine unwanted critters or larger, more terrifying beings. One might picture the discoveries one would find in such a place and play detective for crimes unknown, uncovering relics of the past whose value was once immeasurable but now worthless. In all that might come to the individual's mind however, what is ultimately shared in all, and considerably the most pronounced, is the presence that they hold. A presence that can be felt through an image or a description of such a space, one that defies space and time by carrying itself over generations and into minds of distant places. This presence is what gives these sites their name: ghost. As the name suggests, each town contains ghosts that present themselves throughout the remnants of the site, adding to the atmosphere that weighs down on their inhabitants. Feelings of the past linger - hope, temporary success, failure, loss, and loneliness all haunt every space. They leave you wondering what had happened in order for it to come to this unfortunate situation; however, even knowing the answer to these questions there is still an inexplicable presence that lingers in every space, or as sociologist Michael Mayerfeld Bell titles this phenomenon: "the ghosts of place." Although the abandoned towns of Saskatchewan 
all share a similar timeline and circumstance when it comes to the cause of both their birth and their death, it is important to understand that each town possesses unique ghosts that remain individual to every site. "Ghosts - that is, the sense of the presence of those who are not physically there - are a ubiquitous aspect of the phenomenology of place." [Ghosts of Place, 813]. 


\section{Ghost Typology}

"We often use the word 'ghosts' to refer to the scary spirits of the unsettled dead - to disturbed souls who came to a bad and frequently unjust end, and who haunt our anxious memories. I use the term here in the broader sense of a felt presence - an anima, geist, or genius - that possesses and gives a sense of social aliveness to a place."

[Ghosts of Place, 815]

You can sense this presence in the empty streets, in the broken glass of the false front facades, through the unhinged door to spaces unkempt, even in the field where nothing but a few foundations climb out of the ground like tombstones. Ghosts haunt these spaces regardless of what is left of them - visible through photographs and audible through silence. There are many elements to the presence of ghosts, however, and arguably they are not restrained to the type belonging of people. Different categories of belonging are situated in various aspects of the site when it comes to the ghosts present in Saskatchewan's derelict towns.

Of People -

Felt most prominently inside the spaces that they had once made their own, those of people are among the most notable of ghosts that linger. Not necessarily of their souls or personas but of their experiences and memories. As many of the buildings had been were abandoned in a time of despair, many belongings had been left behind telling stories of their 
owners now long gone. Looking at Figures 3.1-3.2 (photos of interior spaces) we are presented with various lost collections and possessions. The memories of people are felt in these spaces, haunting everything from faded pictures to dust covered floorboards. Though the most present emotion felt is one of pain, you can also sense a feeling of hope in the midst, however lost it may seem now. Every one of the homes or buildings had a new beginning at one point and though nothing human has lived inside its walls in many years, the light that filters through the dirty windows carries images of pleasant times, when it did not seem possible that misery lied ahead. The light is sparse though and left in the spaces between are feelings of discomfort - anguish, desperation, and hopelessness - painful memories strewn across the monochromatic surfaces like the irregularly placed objects, all left uncollected.

\section{Of Things -}

The second grouping of ghosts belongs to that of the built environment, and the various items held within it. Every vacant building and idle object is haunted by a time when it was once used to fulfill the needs or desires of its inhabitants. They seem to yearn for the life they once had. At the same time, they almost forebode new visitors from their accompaniment, as if they wish to be removed from their current dilemma but only by the ones that left them there in the first place. The sharp edges of torn floorboards warn of danger to anyone who wishes to depend on them, but they also bitterly mourn their once well-kept surface. These emotions are not strictly limited to the interiors though. They cover everything from the nameless street signs to the overgrown and fractured sidewalks. (Fig. 4.0). Now unable to direct anyone as to the street they stand on, the signs that remain have had their titles torn by years of wind and rain. 
Sidewalks lay useless as the ground adjacent to them proves to be of better service in comparison to their shifted and buried concrete forms. There isn't a thing that has been untouched by time, and due to that, they all carry faded memories of what they had once been.

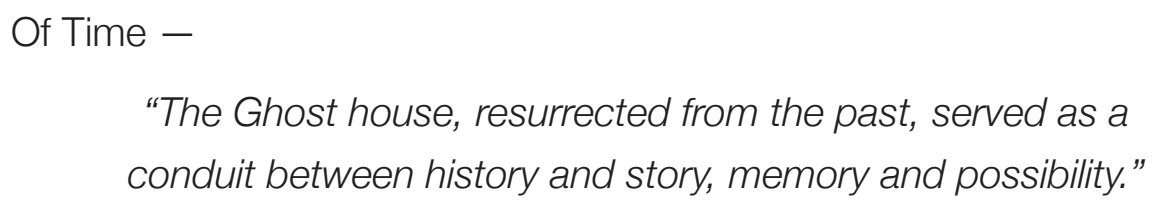

"The Ghost house, resurrected from the past, served as a conduit between history and story, memory and possibility."

[Ghost, 16]

As the towns' occupancies were short lived, the dilapidated buildings and overgrown sidewalks are not signs of function, but rather of time. Time has worn on the ghost towns in a number of ways, and each period has left its presence, stalking every one to come after. Because of this, we are left with a feeling that we do not belong in this place. The previous eras fight against one another to make themselves known, leaving no room for the current generation. "Ghosts also help constitute the specificity of historical sites, of the places where we belong and do not belong, of the boundaries of possession by which we assign ownership and nativeness." [Ghosts of Place, 813]. Upon initially viewing and exploring one of the towns, it is unclear how much history lies in its lost forms. Although it is clear that the site was home to the people that attempted to make their way anew in the beginning of the 20th century, the decay raises questions of who was there after the temporary success, and also of what may have been there before. For centuries the land had belonged to one story;, then in a span of fifty years, it was turned into something entirely new and not long after that was all left be- 
hind - suddenly belonging to many stories. With the rise and fall having left the deepest impression, it now only carries each of these stories in the disrepair of what remains of that short time. "In that sense memory needs to be understood as the trace of all that has gone before, whether it exists today as a tangible remain or as a vague yet lingering mental presence." [Spatial Recall, xiii].

These classifications help to understand each site, making sense of the often uncomfortable feelings they bestow upon us. For as long as the sites remain, the experiences of today continue to be engraved into their daunting presence. No town is left without the memories of those who've stepped foot in it, building upon pictures of the past. "Ghosts are, I argue, ubiquitous in the places in which we live, and they give a life to those places. Ghosts are much of what makes a space a place." [Ghosts of Place, 815]

\section{Anecdote:}

For a period in time, my father lived in a Saskatchewan ghost town. His was the only occupied house, but there were a few shells of former homes, as well as a sturdy yet unused grain elevator. As an adventurous child with many imaginative siblings, I explored every inch of this place, making up stories of the people that lived before. Although there was much left to the imagination, there was also a lot to base our stories off of: with the objects and clothing left behind, it was easy to figure out the structure of a family in any particular house. A garage that had no frame, only a slab and some rusty hunting tools, was one particularly eerie place that had our minds running wild. In it were old bloody rags, 
large chains, and metal hooks; we were too young (or too enthusiastic) to realize what they were actually used for but the stories we came up with for the place are cemented in my memory of it. Balancing over the edges of old foundations, making rafts out of broken doors, and having picnics in the shells of what was once a kitchen were some of our favourite things to do. Though these memories differ greatly from the ones of the people who once lived in the town, they add to the lingering ghosts in its place. Having been back there last summer, I could feel the presence of both my history as well as those who came before. 


\title{
Ghost Architecture
}

\author{
"A ruin is a fragment of a whole that somehow, some way, \\ embodies a sense of prior times. Even in its incompleteness \\ the fragment suggests a greater entity once whole. The \\ ruin provokes our memories. It whispers that we should \\ reconsider the past, that we should think about what has \\ been, and perhaps also taunts how we, too, shall be part of a \\ ruin in times to come."
}

[Spatial Recall, 212]

Any building that once had life but has since been left to degrade, withstanding the elements of nature on its own, is ghost architecture. Revealing itself in ways individual to each fragmented form. These grim and often foreboding structures tell many stories, both of their meager beginnings and of their dreadful abandonment. As all of these towns had been built within the same area and era, their architectural typology is quite consistent. (Fig. 5.0 - 6.0). It is common to see, when buildings are still in existence that is; : their construction consisting nearly entirely of wood, fake store fronts - an exterior wall at the street front of a building that squares off the gable roof and creates a larger appearance, asphalt siding with a printed pattern to represent a brick surface - which is now often peeling off and hanging in gruesome ways, and thick asphalt shingles on the roofs. The only actual stone or brick used was for fireplaces and the odd bank. These characteristics define the prairie ghost town, making them easily recognizable and distinct from any other. 
To some, ghost architecture is more about what is built from the traces left on site of the structures. Architect Bryan Mackay-Lyons uses building relics found in Nova Scotia's coast to guide in the creation of new forms, constructed directly on top of those discovered. In his novel that tells of the account of one of these projects, titled "Ghost," the way in which this is taken on is detailed.

\begin{abstract}
"In the design process, architects still use trace to carry one set of building studies forward into the next. In analysing a site, they look at layers of habitation, seeing the cumulative traces of human settlement as a palimpsest of marks made on the surface of the earth, scraped clean with each successive wave of settlement to be made anew, yet carrying the faint records of earlier patterns. On the Ghost site, MacKay-Lyons works with exactly such traces, identifying the lines, residues, and marks of earlier buildings to anchor - or better, to root-his new works in this time-scarred landscape." [Ghost, 20]
\end{abstract}

The presence of ghosts manages to endure time, continuing to grow rather than fade as the physical traces of the towns do - persisting in every fragmented street and lingering in the afterthoughts of anyone who walks them. 


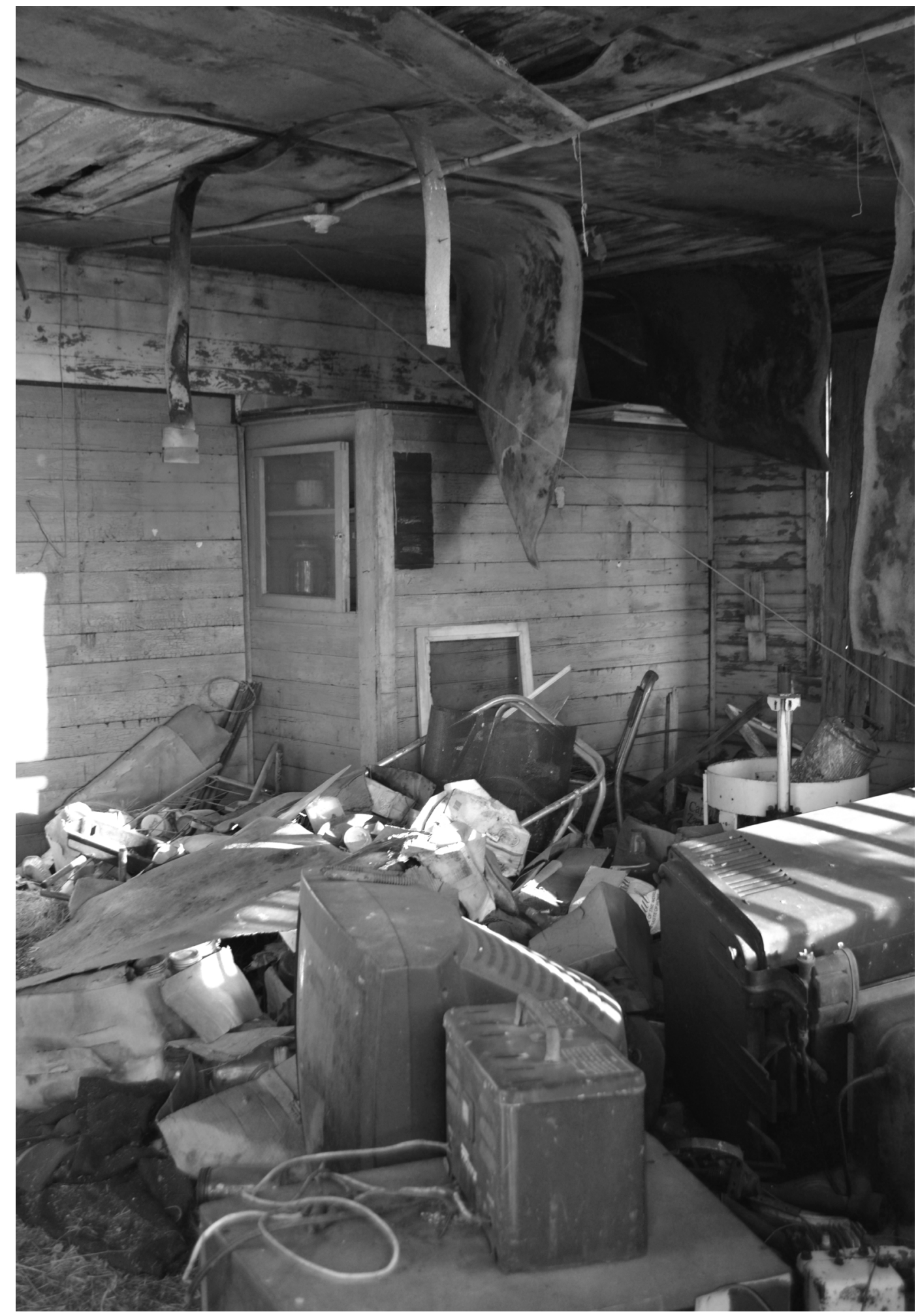

Fig 3.1 View inside abandoned home in Crichton, SK 


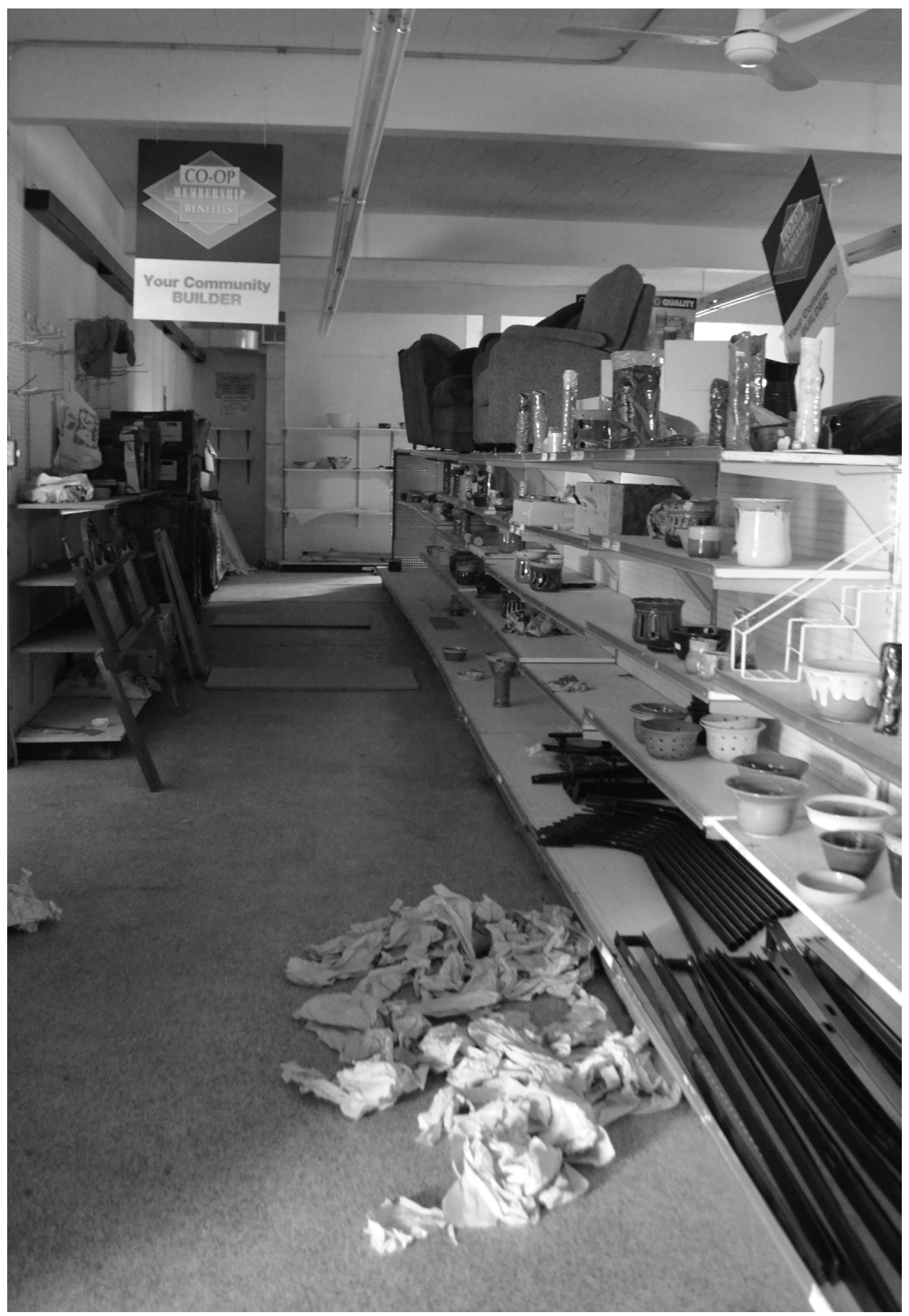

Fig 3.2 View inside abandoned Co-op in Admiral, SK 


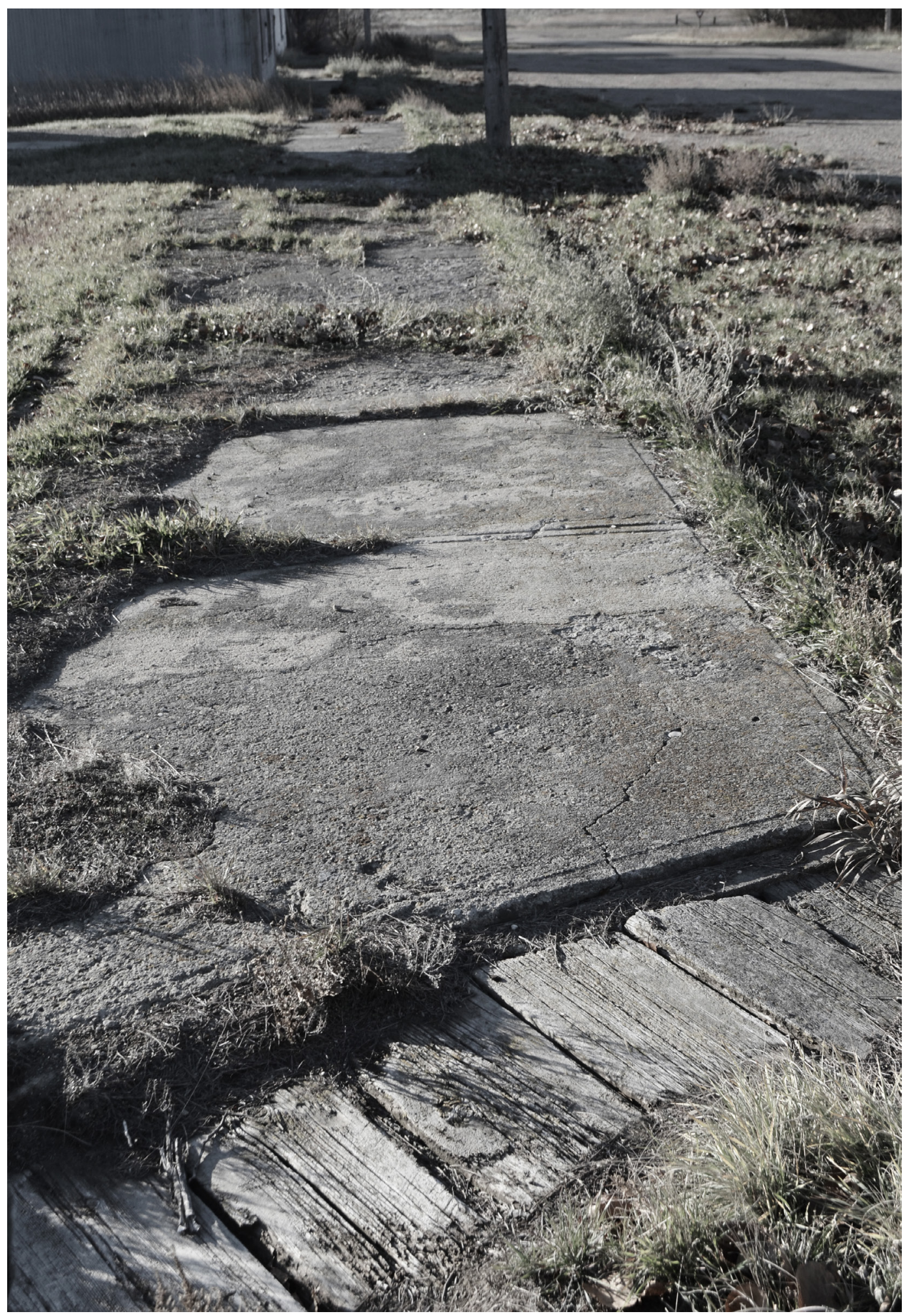

Fig 4.0 View of derelict sidewalk in Admiral, SK. 


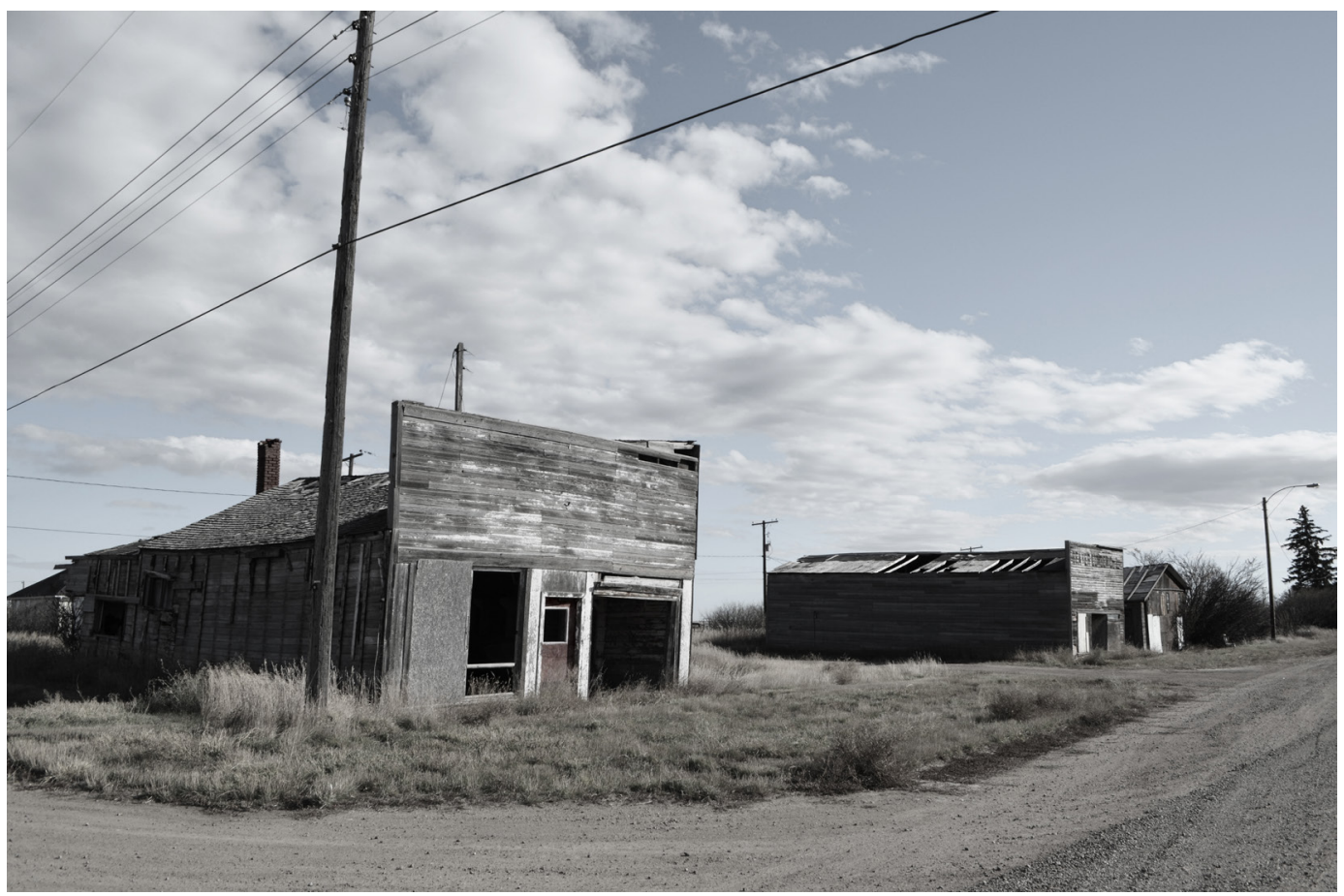

Fig 5.0 Typical fake fronts. Quita Street, Robsart, SK. 


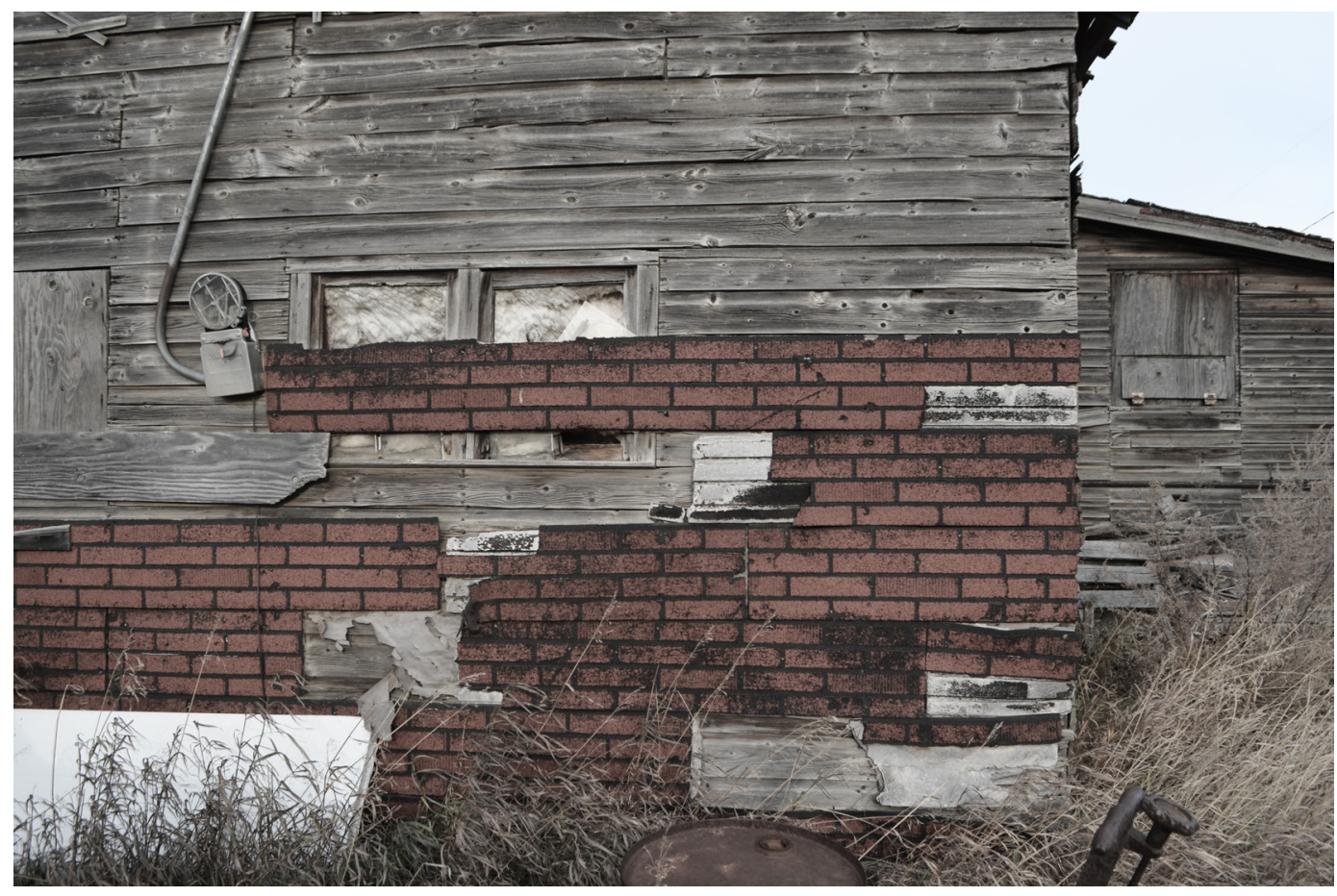

Fig 6.0 Asphalt "Brick," siding material often seen in Saskatchewan's ghost towns. Khedive, SK. 


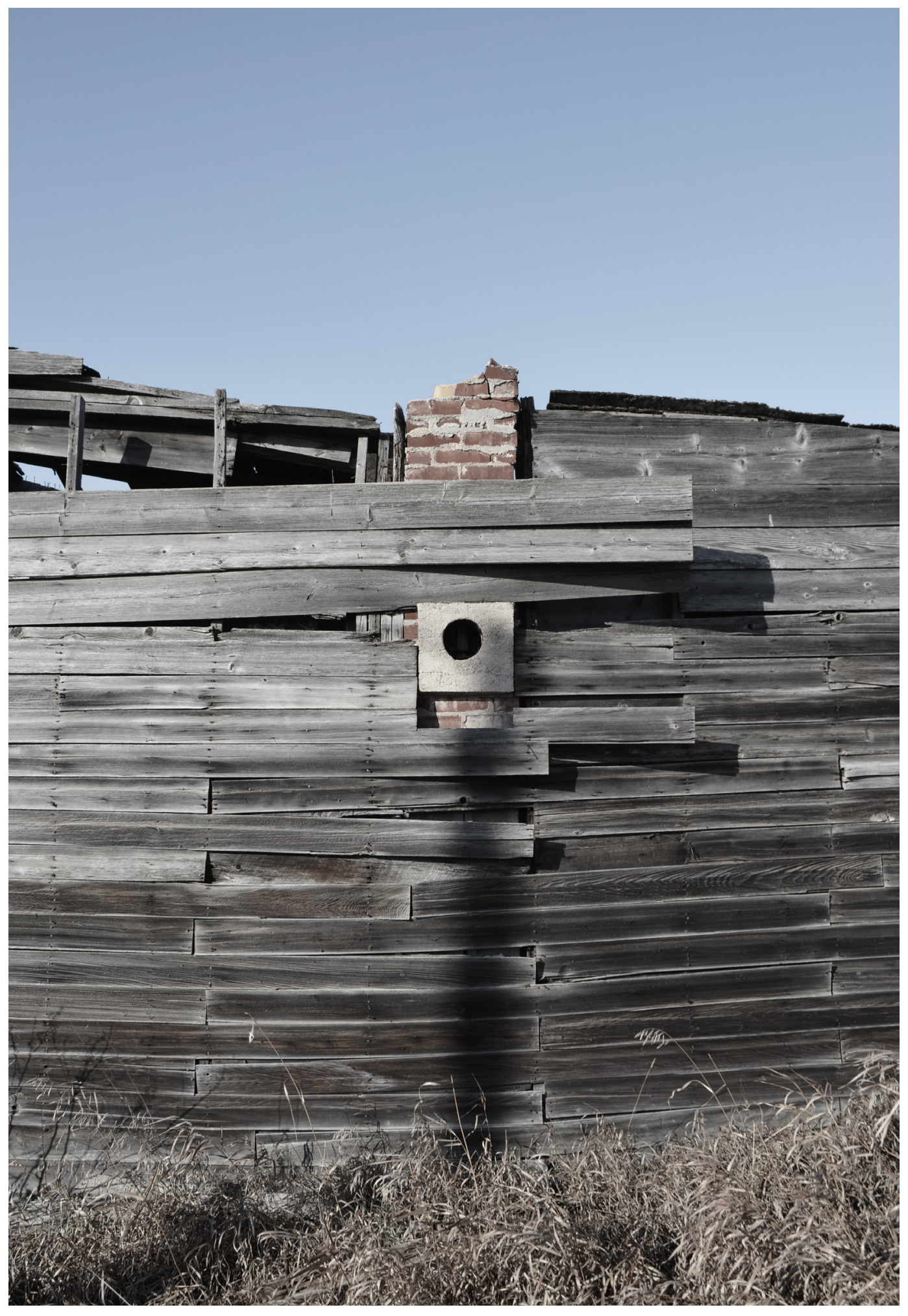

Fig 7.0 Brick chimney. Wauchope, SK. 


\section{2 \\ History of a Saskatchewan Pioneer Town}

"At the top of the little rise where he had placed the marker, my father let the blade down. It scraped the gravel for a few feet, then bit in, furrowing the three-inch sod bound together with the roots and remains of grasses, flowering plantsroses, yellow bean and prairie crocus. This sod had kept the surface intact for the ten thousand years of wind and rain, frost and sun and snow, since the retreating ice-sheet abandoned its hundreds of feet of debris shorn from rocks of the northern shield to form the happy hunting ground of a succession of nomad wanderers until the farmers came, intent on destroying that millennial ground-cover to produce a year or two of intensive crops until the exhausted fabric began to unravel and fall into ruins before the incessant beating of the wind."

[The Middle of Nowhere, Rediscovering Saskatchewan, 79] 


\section{Settlement of the Prairies}

"Europeans believed they had discovered it, that it was an empty and lonely place before they arrived bringing civilization and order. [...] In fact the North-West was alive with people, languages, and interests, a place big enough for everyone.

But it would not last." [Middle of Nowhere, 2]

After recommendation for a police force was granted, giving the prairies the North-West Mounted Police in $1873^{1}$, treaty makings began with the Aboriginal peoples that had been living freely on the land for thousands of years. Many of the Chiefs withheld from signing as long as they could, as "they saw the future more clearly than most and understood that treaties spelled the end of their freedom and their way of life." ${ }^{2}$ Eventually, they were left with no other option and retreated to the land that the colonialists 'reserved' for them, a fraction of what they knew as their own. When all of the prairies had been taken over and mapped by colonialists in the late 1800's, the way in which it was described to foreigners changed drastically. "The image of the west was transformed in Canadian writings from a semi-Arctic wilderness to a fertile garden well adapted to agricultural pursuits," ${ }^{\prime 3}$ and so began a new age for the prairies. Campaigns to bring people in from around the globe

1 Dennis Gruending. The Middle of Nowhere: Rediscovering Saskatchewan (Saskatoon: Fifth House, 1996), 2.

2 Ibid.

3 Ibid. 
were propagated in an attempt to settle the area as quickly as possible. Foreigners - mainly European, American, and Russian - were told of the vast beautiful land and of the nutritious black soil that made this a superior place for agricultural endeavors, "proven" by the numerous success stories from people who had already begun their venture in the west.

An excerpt from "The Prairie Lands of Canada," a brochure sent to entice potential settlers to come to Canada's West:

TO THE INTENDING EMIGRANT.

The time having arrived when Canada may fairly invite immigration from all parts of the Old World, to her vast and magnificent Prairie Lands of the North-West; presenting a new and vast field for prosperous settlement and commercial enterprise; within twelve to fourteen days' travel of Liverpool and as many minutes communication by telegraph from nearly all parts of the world, to the heart of this rich country. Already that great civilizer of this century, the locomotive, is rapidly pushing forward the completion of our great national work, the Canadian Pacific Railway, and now connects the Commercial centre of Manitoba with the whole Railway system of the Continent.

No longer will the Prairie Lands of the United States occupy the attention of the whole world. Canada can now cry aloud in every language to millions: Everyone that wants a farm, come 
and take one, where you may enjoy health, happiness and freedom under the flag "that's braved a thousand years," and where the industrious will soon attain that end to which all men aspire, INDEPENDENCE.

The ancient maxim has been "Settle up the country, and the people will build railways if they want them;" Canada's new and better maxim is now "Build railways and the country will soon be settled," and she is now building a railway from the Atlantic to the Pacific one thousand miles of which will run through the centre of this fertile prairie country.

Brochures like this one, as well as many posters (Fig. 8.1-8.2), painted colourful pictures of life on the Canadian prairie, accomplishing exactly what the government wanted. Between 1901 and 1931, Saskatchewan went from a population of just under 100,000 to just under one million, at 921,000 (for reference, it then took another seventy-six years to reach and maintain one million, in 2007). ${ }^{5}$

Division of Land:

In preparation for the thousands of people set to immigrate to the province - nearly all for farming pursuits - Central and Southern Saskatchewan was divided into a grid system of land parcels deemed ready for

4 Cheryl Avery and Jene M. Porter. Perspectives of Saskatchewan (Winnipeg: Univ. of Manitoba Press, 2009), 129.

5 "Canada's Population Estimates." Statistics Canada: Canada's National Statistical Agency. https://www150.statcan.gc.ca/n1/daily-quotidien/071219/dq071219b-eng.htm. 
homesteading. Land was nearly given away for free; ten dollars 6 bought one of these quarter-section parcels of land (a quarter mile squared or 160 acres) and increments sold quickly to eligible applicants. Railways, roads, farms, and townships were all created according to this grid, and this division of land still guides the infrastructure and landscape development of the province today. (Fig. 4-6, or for more detailed information refer to this website. ${ }^{7}$ )

6 Avery and Porter, Perspectives of Saskatchewan, 3.

7 Statistics Canada, "Canada's Population Estimates." 


\section{Railway and Town Development}

During this time of mass settlement, 7,403 kilometres of new railway was built between Saskatchewan, Alberta, and Manitoba. Saskatchewan bore the majority of this construction, with over 4,188 kilometres of new

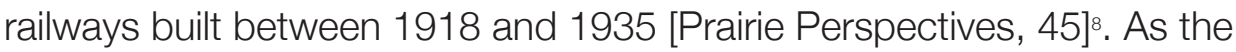
main lines had already made way through the province by 1915, with just over 8,570 kilometres of rail being accomplished, the majority of these new lines were considered 'low density' and connected many small communities to larger centres, as well as to each other. Although the decision to implement these new lines has now been referred to as a 'catastrophic' mistake economically', they brought prosperity to dozens of the pioneer towns that ran along them. Because of their development, villages that were struggling to gain footing were able to have access to immediate supplies for building. Communities soon became hubs for local farmers that brought in grain, creating more traffic, and therefore more businesses within them. "Railways ... were as essential as rain and sun to progressive settlement on the Canadian prairie" [Prairie Perspectives, 46]. Existing towns were not the only beneficiaries of these new lines. Many of the single stations along it attracted new settlement and business, and soon 57 of the stations became incorporated villages ${ }^{10}$, providing the surrounding farmers with necessary services. Small

8 Charles W. Bohi and Leslie S. Kozma. "Interwar Rail Construction in Saskatchewan and Alberta: An Evaluation." Prairie Perspectives Vol. 11 (October 2008), 45.

9 lbid.

10 Avery and Porter, Perspectives of Saskatchewan, 62 
communities that heard of the coming rail became hot spots for business ventures: "Four years earlier, before the arrival of the railway, Moose Jaw businessman William Govenlock negotiated a land-sale agreement with the CPR to build a town site. When the rail line was extended to Govenlock in 1914, it was a guarantee to settlers that a steady flow of supplies would reach the new town and its growing number of businesses" [Ghost Town Stories of the Red Coat Trial, 108]. In addition to essential services, social amenities such as schools, churches, rinks and the like were also created due to the increased traffic that the businesses brought, allowing for relief to the near total isolation felt by many in rural Saskatchewan.

An estimated 900 towns and villages were created in the first thirty years of the twentieth century, mostly built along the rail lines ${ }^{11}$. Not only did the railway provide supplies and accommodate travel, but it was also used for the export of grain and led to numerous elevators that rose along the lines (Fig. 7). These elevators were essential to the prairie life as they were used for the storage and transfer of grain that was being exported from every farm within the province. By 1931, well over half of the farms were within 6-10 miles of one of these elevators ${ }^{12}$. At the time, it was necessary for them to be so close as it was already a large distance to be traveled by a team of oxen or horses pulling a load of grain to the elevator. This meant that the towns and villages were also within roughly ten miles of each other, dotting along the thousands of miles of railway lines that covered the province.

Avery and Porter, Perspectives of Saskatchewan, 130

Avery and Porter, Perspectives of Saskatchewan 132 


\section{Not All is as Perceived}

The topic of immigration to the Canadian prairie was alive with the excitement of new beginnings and the hopeful promise of good fortune ahead. However, though the conditions at the time were ideal for farming in Southern Saskatchewan with above average precipitation and higher prices for wheat, most - if not all - of the statements and stories used to draw in settlers were substantially stretched from the truth. Many families came in with the promise of large homes, healthy crops, and hearty meals had by all; here are just a few stories that tell of the reality they were introduced to instead:

"Our host, who had emigrated to Canada a year or two before, had written us to boast of the prosperity he had attained in such a short time. He said that he had a throne like a mansion, a large cultivated field, and that his wife was dressed like a lady. In short, he depicted Canada as a country of incredible abundance whose borders were braided with sausage like some fantastic land in a fairy tale.

How great our disenchantment when we approached that mansion of his and an entirely different scene met our eyes! It was actually just a small log cabin, only partly plastered and roofed with sod. Beside the cabin was a garden plot which had only been dug with a spade. The man's face was smeared with dirt from ear to ear, and he looked weird, like some unearthly 
creature. He was grubbing up stumps near the house, and his wife was poking away in the garden. She reminded us of Robinson Crusoe on an uninhabited island. She was suntanned like a gypsy and was dressed in old, torn overalls. A wide brimmed hat covered her head."

["Beginnings in Canada," in The Middle of Nowhere, 73].

"The palace was all of 14 feet wide by 18 feet long, made of one inch boards and lined with single ply paper for insulation against the wind. The ceiling was made of $3 / 4$ inch boards that were found lying about. However, the boards were covered up with paper to keep the rain from dripping into the house."

[Uncle Mike's Edenbridge, 19].

"...others were coming to Senate to live out their hopes and dreams. More often than not, those hopes and dreams were shattered at first sight. The land was bleak, desolate and dry. Grasshoppers and marauding rabbits had feeding frenzies on whatever crops managed to poke out from the parched soil."

[Ghost Town Stories of the Red Coat Trail, 99].

Nearly every immigrant was ill equipped for the harsh winters, dry spells, and lack of civilization they were faced with. It took most over a week of travel and much of their earnings to arrive in the "magnificent land," and there was no consideration of turning back. The quietness of the prairie 
and the ability to live and work on one's own terms was what many had yearned for in the first place, and though shook by the alternate reality they faced, hope of the promises made to them carried on. The people became accustomed to setbacks and remained resilient through the years, though little could prepare them for the many adversities that lie ahead. 


\section{The Beginning of the End}

“When southern Saskatchewan dried out in the 1930's, many farmers abandoned their land, loading their buggies or trucks and heading for areas farther north where they hoped to reestablish themselves."

[“North to Cree Lake," The Middle of Nowhere, 121]

Rural depopulation had already been seen in the first few years of the 1920 's when wheat prices took a dramatic drop, proving unbearable to many, with 900 farms having been abandoned in 1926'13. A period of good fortune in terms of wheat prices and crop production occurred in the latter half of the decade, however, which brought in a final wave of settlers; it was the last of such an influx to take place for the province.

\section{Extreme Drought:}

As the whole North American continent began feeling the effects of the Great Depression in 1930's, Saskatchewan was dealt a much worse situation parallel to the economic crisis. Severe drought that lasted through the years now known as the 'Dirty Thirties' brought misery to the entire province. Crop failure was extreme and as result, the province's income declined 90 percent within two years (net agricultural incomes for the

Avery and Porter, Perspectives of Saskatchewan,132 
years of 1931 and 1932 were reported in minus figures) ${ }^{14}$, "forcing 66 percent of the rural population onto relief" ${ }^{15}$. The railways, though less used for grain transportation, became vital to the survival of the townspeople; "two in three members of the farm population were destitute and without the Interwar branch lines, getting supplies to the stricken areas would have been even more difficult" [Prairie Perspectives, 65]. With no relief to the drought, grasshoppers and rabbits overtook what was left of the fields and dust covered every surface, both outdoors and in. The fast population growth that the province had been experiencing in the previous decades reversed, as immigrants began to be turned away or even expelled if they had not found work, and birth rates slowed. ${ }^{16}$

"The year 1937 brought the worst disaster of all. No rain fell, the wind blew what little topsoil remained in the fields into the roadside ditches; dust-clouds-black, sinister, shot through here and there with eerie shafts of light-wavered all day and every day between earth and sky, and the heat was appalling."

["Desolation," Middle of Nowhere, 108].

Rain finally came back in 1938, but the economy didn't return until 1942 by which time 1,800 farms had been abandoned ${ }^{17}$. Though astonishingly large, this number could have been even greater had it not been for the ongoing economic depression that continued alongside the crop

\footnotetext{
Gruending, Middle of Nowhere, 108

James Struthers, "Great Depression." The Canadian Encyclopedia. https://www.thecanadianencyclopedia.ca/en/article/great-depression.

16 The Canadian Encyclopedia, "Great Depression."

17 Bruce Dyck. "Dirty Thirties: Fact and Myth." The Western Producer. https://www.producer.com/2005/07/dirty-thirties-fact-and-myth/.
} 
failures. Many farmers were forced to stay and withstand the drought due to very slim options for employment elsewhere. The people of Saskatchewan were affected deeply by this agonizing period, leaving a lasting impression on the attributes of prairie culture that was carried down for generations.

\begin{abstract}
"The rains that fell at last and the erstwhile desert rejoiced and blossomed like the rose; but no amount of rainfall could ever wash away the dreadful memories of the agonizing struggle to survive. For the people of Saskatchewan that nine years' sojourn in a dust-darkened wilderness was a genuinely traumatic experience which has left its mark not only on those who actually lived through the Dirty Thirties but to some degree on their descendants."
\end{abstract}

[“Desolation," Middle of Nowhere, 109]

The long period of drought was possibly the greatest hardship felt by the province's people as a whole. Unfortunately, though, it wasn't the end of nature's vengeance on the land. Shortly after that devastating decade, a series of floods wiped out the crops that had just begun to prosper, resulting in another small wave of farm abandonment. 
Restructuring of the Prairie Landscape:

Financial strain caused by the extreme weather and low grain prices left farmers with great debt. Income gained from crops remained marginal even after the depression and drought. It became evident that the original homestead model was not viable agricultural production in Saskatchewan. In order to continue as a sustainable business, farmers needed to increase their land acquisition. This drove the industry to depend on advancements in the technology of farm machinery in order to accommodate the size of the crops.

The steady move from oxen and horse driven carts to the use of automobiles as a means to carry grain loads meant that there was no longer a need for grain terminals to be so close together. Farmers could go to larger terminals to export grain, rendering the smaller terminals redundant. The Second World War also brought many changes to the field. The technology used to develop tanks and armoured vehicles was adapted for agricultural production. Tractors and their various attachable apparatuses became a staple to every farm. The new methods required far less work to maintain the same or larger amounts of land, and the size of individually owned farms began to increase substantially. When land was first divided for agriculture, it was purchased in quarter sections or 160 acres. The average farm size in the province is now 1,784 acres $^{18}$, over ten times the original and with no greater number of labourers required to maintain them. These changes developed quickly and the infrastructure required to support these changes required a radical 
transformation of the existing conditions.

"Some Saskatchewanites would have realized that farming had been overextended into areas that were too dry to support cropping under normal moisture conditions. Few, however, would have comprehended the tremendous structural (and, consequently, spatial) imbalance that had developed. Every sector of the prosperous Saskatchewan economy that existed in the spring of 1929 had been built with nineteenth-century technology. The newer technology, which was available even then, required much less labour per unit of production and inevitably would replace the old. The economic history of Saskatchewan from 1929 to the present is dominated by the occupational and spatial adjustments necessitated by the adoption of the technologies of the twentieth century."

[Perspectives of Saskatchewan, 133]

Railway Abandonment:

Although hundreds of little towns saw many benefits from the 'low-density ${ }^{\prime \prime}$ railway lines at the time of their construction, the majority of them are now either abandoned or removed entirely. Due to the economic despair felt by the country during The Great Depression, pressure was put on authorities to do something about the astronomical costs these new rail

Avery and Porter, Perspectives of Saskatchewan, 136 
lines had brought, resulting in an immediate halt to all new construction and even termination of the use of many existing lines. Later, 185 kilometres of railway were pulled up during the 1950's, with another $595 \mathrm{ki}-$ lometres following suit in the early 60's, and by 1975, another 845 kilometres were discontinued (Fig. 8). This meant that the elevators along these abandoned lines, which were once vital to every town and farmer nearby, could no longer be relied on to export grain and loads had to be brought to larger terminals. This, along with the fact that one tenth of the initial amount of farmers were needed, resulted in a dramatic reduction to the amount of people coming into the towns and supporting the local businesses. The success of any small town was directly related to the agrarian culture, and therefore they slowly began to depopulate.

Development of new highways deepened this cut as they were built to directly connect the larger centres to one another, leaving little reason for anyone to pass by the communities that didn't fall along these routes. One by one, businesses closed and the townspeople were forced to find work in those larger centres, leaving behind homes and shops with no willing buyers to replace them. The last service to close in a town was typically the post office. When it did, the death of the town was inevitable and the dissolution of the corporation soon followed.

Between 1941 and 1961, Saskatchewan's rural areas lost 180,000 residents to the more urbanized areas of the province. During this time, around 100 of the rural towns that were either small in number or in less convenient locations, or both, had dissolved. Through the 1950's, 1,250 public schools in similar areas were forced to close, with another 1,500 closing in the following decade, shifting the population even 
further towards urban areas. Nearly 400 post offices were closed and the number of towns that were considered "viable trade centres" went from 138 in 1961 to 24 at the closing of the century ${ }^{20}$. While $84 \%$ of the population lived in the rural areas of Saskatchewan in 1901, has dropped to only $33 \%$ as of $2017^{21}$.

20 Avery and Porter, Perspectives of Saskatchewan, 136

21 Heather Hall and Rose Olfert. "Saskatchewan." State of Rural Canada. http://sorc.crrf.ca/saskatchewan/. 


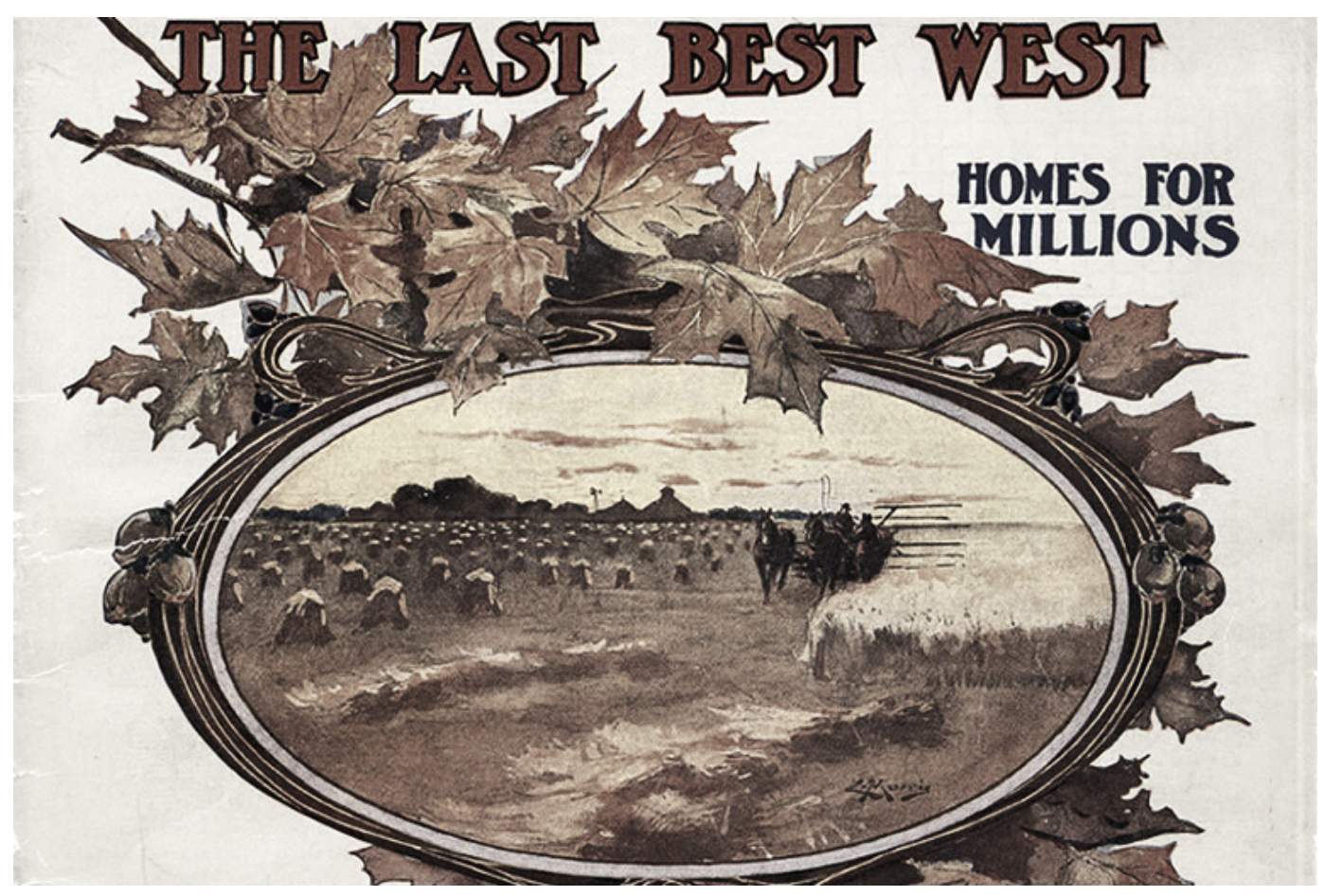

Fig 8.1 Promotional Poster for Prairie Settlement, 1909.

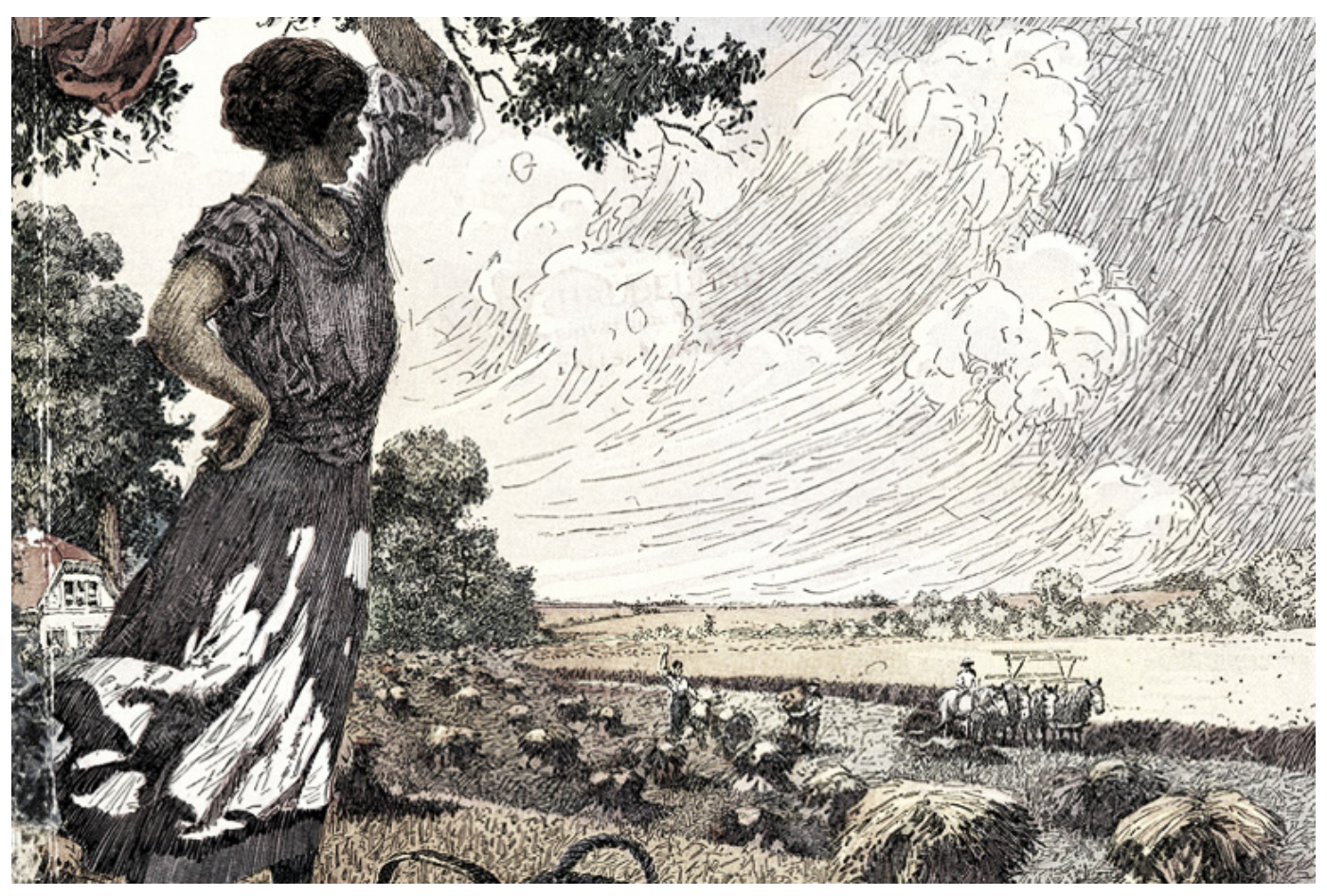

Fig 8.2 Promotional Poster for Prairie Settlement, 1921. 
PLAN OF A TOWNSHIP

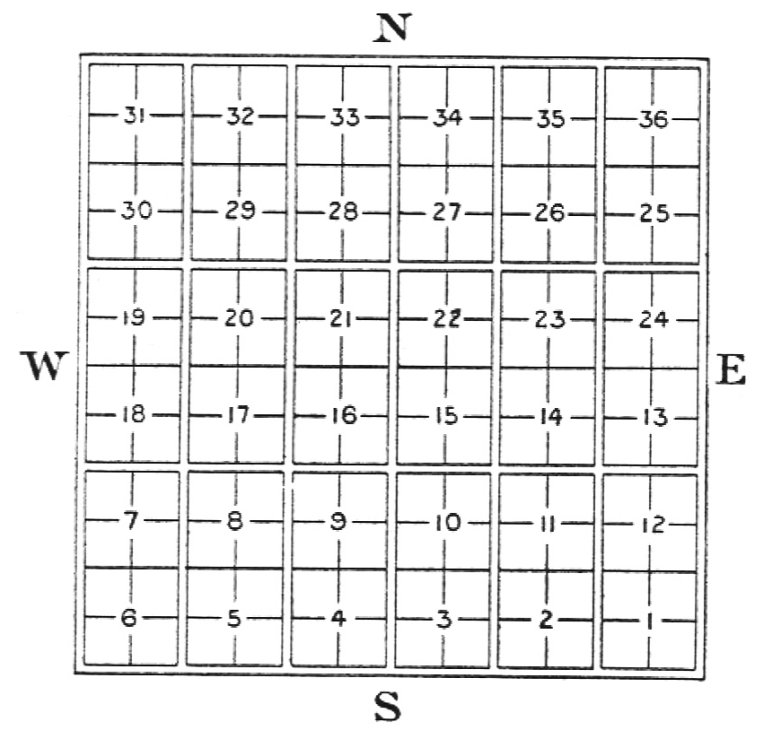

Fig 9.1 Division of Land into Townships.

PLAN OF A SECTION

$\mathbf{N}$

\begin{tabular}{|c|c|c|c|}
\hline 13 & 14 & 15 & 16 \\
\hline 12 & 11 & 10 & 9 \\
\hline 5 & 6 & 7 & 8 \\
\hline 4 & 3 & 2 & 1 \\
\hline
\end{tabular}

S

Fig 9.2 Division of Land into Sections. 


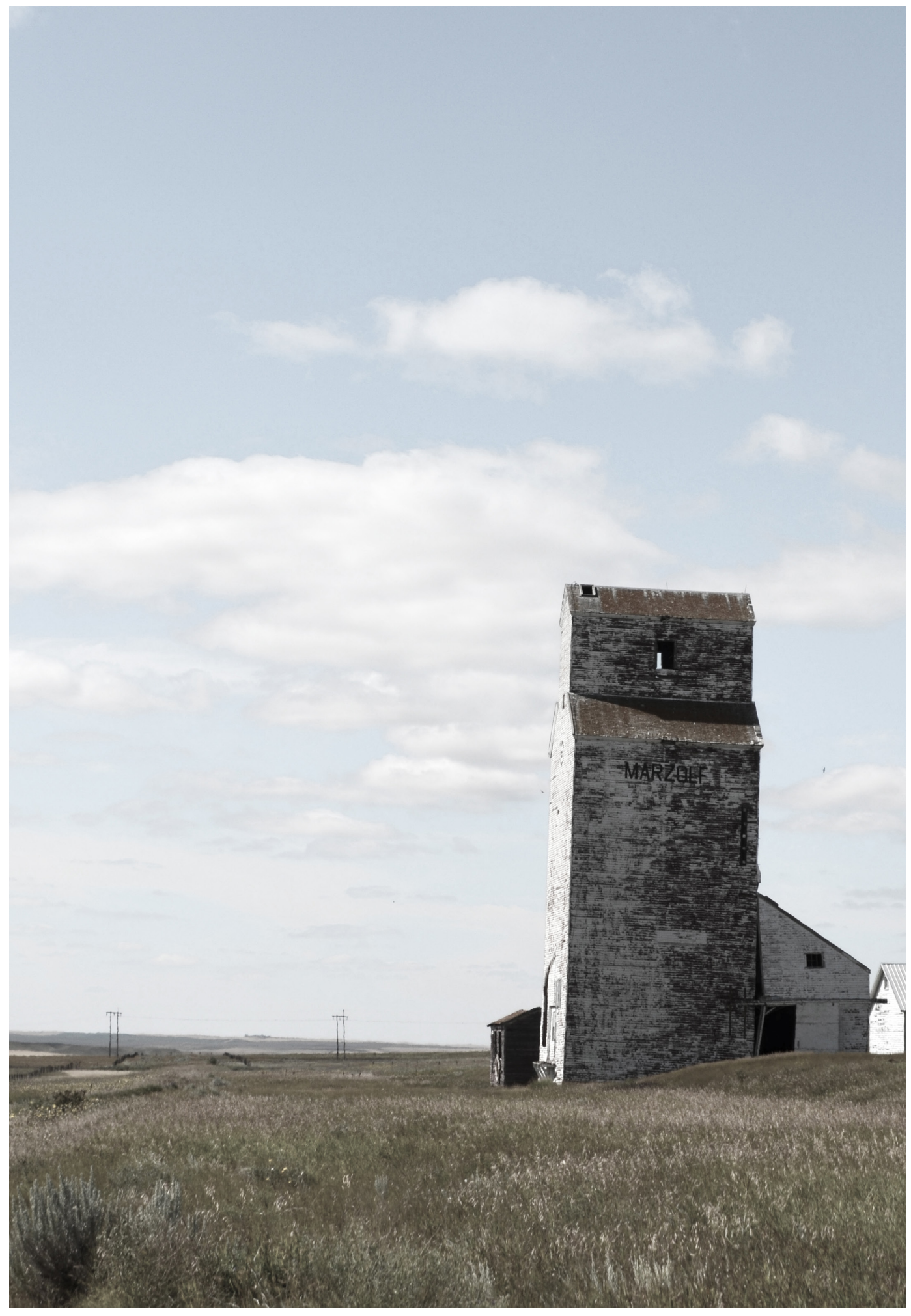

Fig 10.0 Abandoned grain elevator. Thunder Creek, Sk. 


\section{3 In a State of Dissolution}

"In 1983, the new store owner in Senate closed shop. That signaled the end of the hamlet. In 1994, with the railway and elevators also gone, rural municipality officials brought in the bulldozers and leveled Senate's remaining dilapidated buildings. Part of the debris was dumped into a nearby landfill. 'It died a bad death,' Paul says sadly. Every once in a while though, he returns to the bluff alongside the Red Coat Trail where his store once stood. It's usually silent there, except for the cars passing by on the highway. Still, if the wind blows just right, memories of the sweet music from days long past can be heard, a ghostly reminder of a time when the Senators played their magic throughout the land." [Ghost Town Stories of the Red Coat Trail, 105] 


\section{Dissolution of Towns}

The effect that rural depopulation has had on the province can be seen in the dramatic loss of towns incorporated in the beginning of the 20th century. There are approximately 350 ghost towns accounted for, (Fig. 2.2) along with many that are unaccounted for, having no designated geo-location on any current search engines (Appendix 02). The beginnings of these towns, as discussed in the previous chapter, shared a common genealogy; however, the way in which they fell apart shares a common narrative. Most of the townspeople did not expect their communities to fail when they were organized into designated places, and they certainly could not have anticipated the amount that their towns would wither during the thirties and continue to decline steadily for decades to come. With over 100 towns having dissolved by the middle of the century, and another 250 to follow, the realization set in quickly. By the time a town had lost all of its businesses and most of its people, the remaining residents could not continue to maintain what was left, nor was there much reason to keep any services going. This is typically when the decision to release the administration or governance of what was left of the town to a larger division, such as a township or province, and the town was then declared an unincorporated community. This is what is being referred to when the state of a town is considered dissolved, or by the date of dissolution.

There are currently 363 unincorporated communities in Saskatchewan, however an unincorporated community does not always dictate whether 
or not it is a ghost town. Many urbanized communities have simply never established incorporation, and would be a fairly large town if they chose to. As well, there are many northern communities fall under this category as well. 


\section{Current Conditions}

The majority of the towns that do meet these terms have little left but their name on a map; some ceasing to even have that. Without intending to search out prairie ghost towns, there is little chance of realizing many of them are even there. Most are passed by without much of a glance as there is seldom anything left to see-save for the sporadic lines of overgrown sidewalk or wreckage of where a building used to stand, neither of which is notable from a distance. Both their physical and mental presence continue to dissolve as time passes.

Anecdote:

My daily travel route from the town I grew up in to the town that I went to school in was about 20 miles (30 kilometres) and halfway along had an elevator marking the ghost town of Lawson. This was the tallest and most notable structure on the route and was as much part of the experience of the drive as the fields that flowed around it. The elevator succumbed to a fire in 2017, however, and there is hardly a trace left of its former grand existence; the town is now nearly impossible to notice with only a small derelict house and shed left in its limits. Many people in the surrounding area still have fond memories of growing up in this town and had lived through its steady decline. The loss of the elevator felt as if now the town has really passed away. 
Highway 13:

One route in particular has more ghost towns than it does living, and to no short coincidence. Highway 13, also known as the Red Coat Trailor even as "Ghost Town Trail" - has roughly thirty ghost towns along its 670 kilometres of mostly patched blacktop. The route received its name from its early history, as it had been the trail first taken by the North-West Mounted Police (now the RCMP) who were sent out to bring law to the prairies in $1874^{22}$. As the railway also ran along this route, there were many colonial towns incorporated nearside at the turn of the century. Nonetheless, they were no safer from the ramifications endured by the events that took place in the 1930's onward. In fact, they were dealt yet another affliction; the Trans-Canada highway began construction not long after the natural disaster and was completed in $1957^{23}$, distancing itself from the Red Coat Trail by only 50 kilometres at points. This contributed to the depopulation of the towns as the route received much less traffic, and when people relocated, they did so to the larger, more prosperous communities along the major highway.

\section{Anecdote:}

I traveled along this route in late October this past year (2018); as I did, I visited thirteen of the ghost towns along it and document-

22 Gail Kudelik, "Red Coat Trail." The Canadian Encyclopedia. https://www. thecanadianencyclopedia.ca/en/article/red-coat-trail.

23 Kenneth Pletcher, "Trans-Canada Highway." Encyclopædia Britannica. https://www.britannica.com/topic/Trans-Canada-Highway. 
ed my experience both on the road and off (as seen in Chapter 04 and Appendix 01). Without the help of Google Maps, I would have missed many of these towns, as there often were no signs to indicate a town was nearby, and it didn't take long to realize why - there seldom was much more than one or two nearly collapsed buildings on site. Even with such little that remained, each place still felt heavy with history and emotions. 


\section{Atmosphere}

The feelings imparted upon each town's visitors are predominately born from the atmosphere that weighs on every site. Felt throughout the architecture and various traces that remain in these towns, an awareness of the past conditions every experience. Even when there is very little there, this atmosphere remains, filled with ghostly memories of past times and weighted by the dead silence. As Marc Treib states, "memory [is] the trace of all that has gone before, whether it exists today as a tangible remain or as a vague yet lingering mental presence" [Spatial Recall, xiii]. In this sense, memory adds a layer of emotion to each site, alluding to the experiences of its former inhabitants, now long gone.

Anecdote:

As I experienced several of these towns first hand during field research in the fall, I realized how quickly this eerie atmosphere could affect your mind if you let it, or, even if you didn't. Despite having been excited to explore every space, there were moments near the end of the day, where dusk was too fast approaching, and the atmosphere of these places quickly grew to something of a horror story. Coyotes howling, deformed shadows cast by decaying structures, just enough of a breeze to rustle the ground, and before you know it, every breath is shortened and every stride lengthened. In broad daylight these places often still feel sinister. 
Although every space drew questions of their reason for existence, abandonment, and decay, one in particular was more peculiar than the rest. Outside was pleasantly warm and sunny, the building situated in overgrown grass just down a near non-existent path. The doorknob to the only entry was tied back by a rusty wire, upon removing it and drawing the door open, a musty smell came rolling out and placed directly in the way of the entry was an old chair, standing on guard between me and the stairs. The boards, rotten and covered in dust, begged not to be stepped on, and paint was peeling off the stained walls. All of this was typical enough, however it was the expansive room at the centre of this building that left a lasting image in my mind. Light filtered in through the thin panes of glass that remained, some boarded up but only halfway. The surfaces of every wall and ceiling were falling off in pieces, broken boards with nails protruding were strewn across the floor, and thick, heavy wires were placed in a wide grid floating at about a meter off the floor, still tight though everything else in the building was falling apart. They more than likely had a simple enough reason for being here but I could not fathom why and it still puzzles me. Maybe if the other characteristics of this building were not so dreary or if the atmosphere inside didn't so deeply contrast that outside, these tense wires wouldn't seem so ominous, but this was not the case. 


\section{Vanishing History}

With such a large presence in the province due to the sheer number of them, why do these towns continue to readily fade and become so easily forgotten? Is it because they had such a short life span in comparison to other international historic towns? Is it because they were built so fast and with little concern to the durability of materials? Or maybe it's because we believe that these towns never should have existed in the first place, the memory of their existence tainted by the destruction that came with, only to result in their demise and ultimately more destruction. Yet, even if this history is difficult to take ownership of, it nevertheless must be accounted for. In many other situations the importance of a tangible history is taken with great consideration. For instance, when development is happening on a site in Rome and archaeological remains are discovered, all construction halts to allow for the documentation and potential preservation of what is found. Maybe this is due to the fact that the historical remains they find are the only way of discovering more about the people that lived in those times, as it was too long ago to communicate with anyone that had experienced it; but if we continue to let the significance of the lives in the colonial period of the prairies disintegrate, they will end up in a similar situation within time. The remains of Saskatchewan's ghost towns are fading faster than ever and the heritage of the prairie culture fades with it; without any sort of intervention, the towns will continue on the trajectory they have been taking until they disappear altogether. Over half of them are now invisible, their foundations - graves - dug up and the earth turned over, as if they were never there at all. 


\section{Resolution}

"... architecture begins to crumble the moment it is fixed and 'finished' being built on site; and the process of deterioration continues throughout the life of the building. We could say that, ironically, once a building is finished being built, it begins its life; and as all with life, the process of ending begins as well. Indeed, buildings do have lives. Any sense of permanence is but an illusion."

[Losing Site, 81]

Although the way in which they began and the way in which they fell remains alive in every site "summoning the past into awareness" [The Aesthetics of Ruin and Absence, 429] as time goes on it becomes harder to recognize. There is no one size fits all solution when it comes to preserving the physical aspects of these historical towns, not in their entirety, at least. Some may become museums of sorts, attractions for curious minds as to what a ghost town is - this cannot by any means be an answer for all, though, as there are far too many. It also begs the question of whether or not it can be considered a ghost town if it is being maintained and well accompanied? The presence of the current would begin to overshadow that of the past. Shelly Hornstein asks imperative questions regarding the value of built landscapes: "Does demolition end a memory? And conversely, does preservation of a building or place preserve a memory?" [Losing Site, 86]. Arguably, the existence of a building or place does hold onto specific recollections of those that have had 
encounters with them, but only for those individuals. For anyone else, these memories only cast a shadow over the building's surfaces, leaving more of an impression than any specific occurrence. So, to save any of these sites from destruction only saves the memories of a select few. As well, any interference of their natural decay deconstructs their natural presence, further eluding their truth - so what becomes of them instead? To let them continue to fade without further intervention could mean total loss of everything they were, from the days of prosper to their scattered and displaced bones. This is already the case for many towns whose images and stories have faded so greatly that even Google is unable to place their faded existence onto a map (Refer to Appendix 02). Furthermore, any information to be found or discovered of them remains scattered, with no collective resource able to tell more than a small fraction of their narrative.

Without the conservation of the tangible forms of these sites being advantageous, thorough documentation must go into what currently exists together with any information that can be collected from their past. The template shown in Chapter 04 outlines what this could look like; in a compilation of existing conditions melded with aspects of the town's situation at its peak, shown through site plans, elevations, views, data, and experiential stories. Information is presented in a way that unifies each town by the way in which they are represented, while allowing their unique aspects to present themselves individually.

Although the way in which the information is presented could take on many forms, it is imperative that the form of cataloguing shown in Chapter 04 outlines a standard practice for the ghost towns of Saskatchewan. 


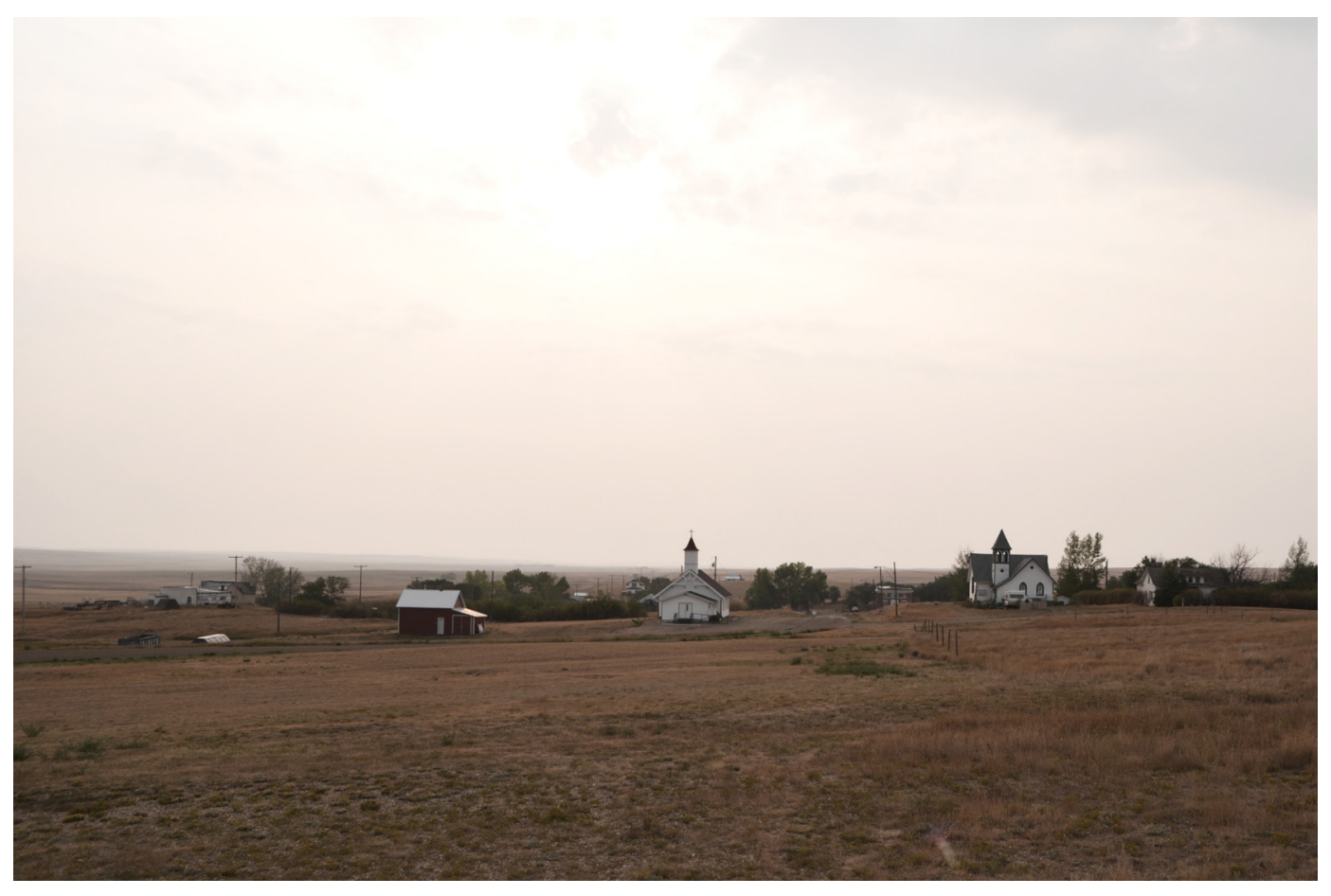

Fig 11.0 View of Admiral, Sk. 


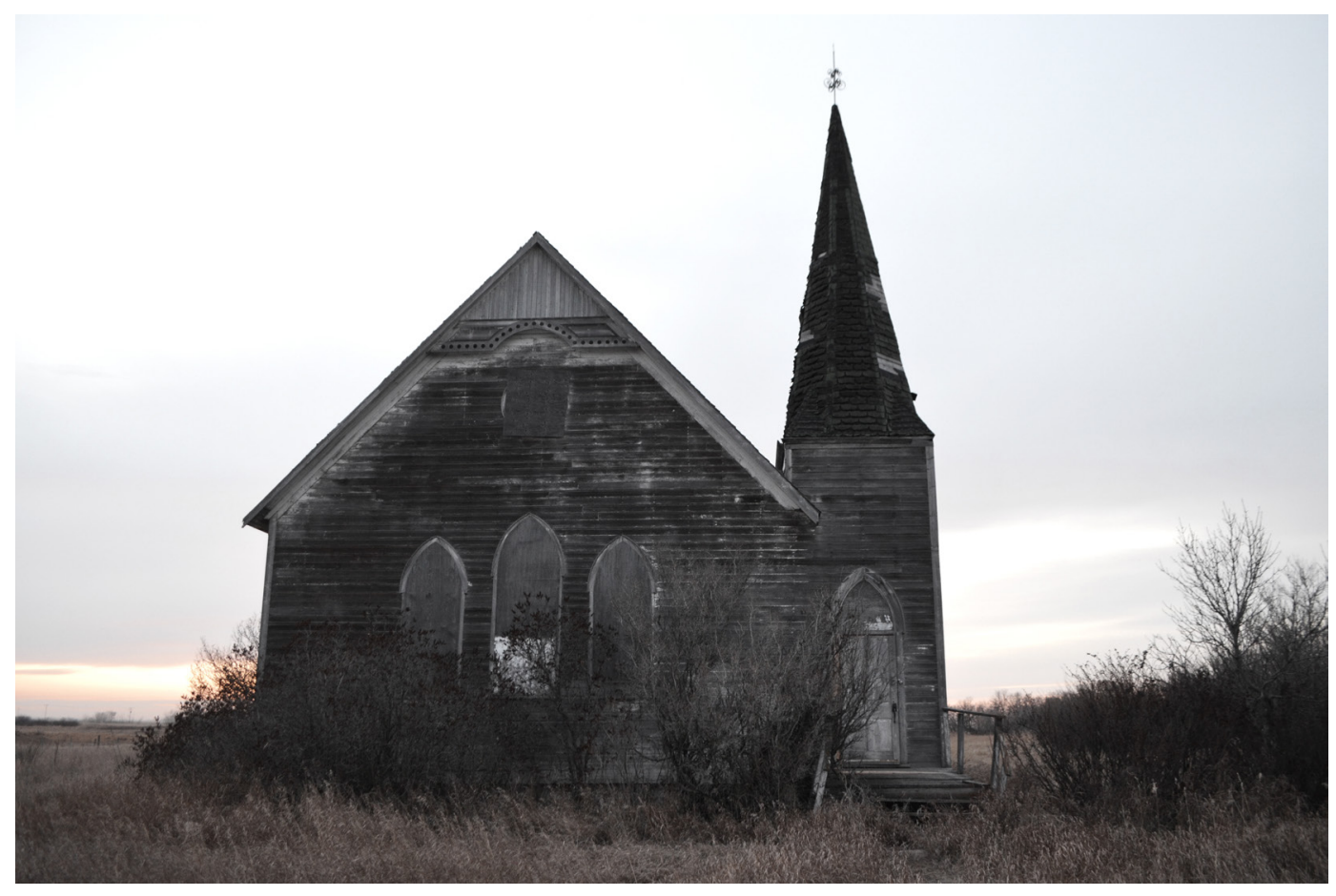

Fig 12.0 View of abandoned church at dusk. Froude, Sk. 


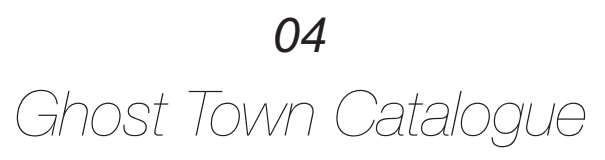

"'The writing is on the wall,' said Boyd Stevens, the store owner. He told us that Orion's last grain elevator - the town's final ray of hope - was about to be demolished. It was one of many slated to fall along the trail. There was once lots of hope, added one old-timer, but things never got any better.

The Red Coat Trail, while picturesque and historical, is a land of ghosts. Faced with the ravages of typhoid fever, drought, dust storms, rabbits and grasshoppers, most hopes of prosperity gradually faded amongst the settlers. And any family homesteads remaining after all that were, for the most part, swallowed up by corporate grain farmers and ranchers. Once the people left, the communities dried up too, leaving numerous ghost towns."

[Ghost Town Stories of the Red Coat Trail, 12] 


\section{Introduction}

Although these towns share a similar construction and decomposition, their individual narrative lies in the experiences of the people that lived through it all. From the initial growth with its distant hope, the thriving years of blind optimism, and finally to the continuous loss and unrewarded perseverance-each town has its own story to tell through its people, structures, and the traces they left behind.

The towns selected to provide example of the documentation methods used for Saskatchewan's ghost towns are all located along Highway 13, also known as the Red Coat Trail. Although this trail contains over thirty ghost towns, thirteen were selected (fig. 18.0) during the process of documentation and five are represented in the sample section giving a full glimpse into the potential of the template.

Starting with Wauchope as the town farthest east on Saskatchewan's portion of the Red Coat Trail, and continuing west until the nearly invisible Govenlock, each of the thirteen towns were documented in a similar fashion. Starting with the filming of the entry into the site from the highway, moving to photos of the facades of each abandoned building, then to $360^{\circ}$ imagery of the street views. As well, the materiality of buildings, decayed sidewalks and street signs and areas of interest were also photographed. This collection provided expansive information on the towns but needed to be refined leading to the template that follows. Therefore the record of each town will begin with some general facts about their 
history such as their date of establishment and of dissolution, as well as known information of their population and buildings. Site plans and street elevations created by a layering of their past and present condition give an overall impression of what these towns look/looked like. Alongside this document, a series of visual experiences have been created which are meant to be viewed in a 360-degree headset. This series encompasses the viewer in the current reality of the town then slowly transitions into a dream-like state of its past through an overlapping of a historical photo onto the location it would have been if still present. The closing view of each of these experiences has been captured and is used here in the template samples to convey the ghosts in each site. Finally, a collection of stories from those who've experienced the town will be incorporated. 
[Template for Ghost Town Catalogue]

\section{REPRESENTATION OF CURRENT STATE}

[WITH HISTORICAL STATE OVERLAYED WHEN AVAILABLE]

\section{TOWN NAME}

19XX - XXXX

[DATE OF ESTABLISHMENT TO DATE OF DISSOLUTION]

LOCATION MAP 
[Template for Ghost Town Catalogue]

\section{STREET ELEVATIONS}

[PAST DATA OVERLAID WITH CURRENT]

COORDINATES

\section{Peak Population:}

Number of Buildings: CURRENT

PAST

Notable Structures:

\section{SITE PLAN \\ [PAST DATA OVERLAID WITH CURRENT]}


[Template for Ghost Town Catalogue]

\section{REPRESENTATION OF CURRENT STATE}

[WITH HISTORICAL STATE OVERLAYED WHEN AVAILABLE]

STORIES OF TOWN

[may use several pages] 


\section{TEMPLATE SAMPLES \\ TOWNS ALONG HIGHWAY 13}




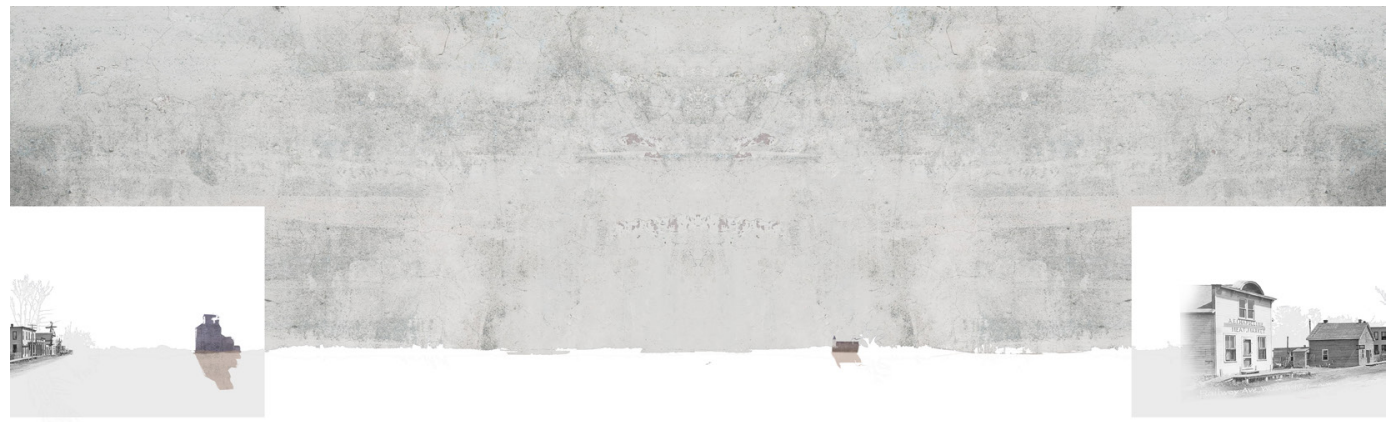

Fig 13.1 360 view with past image overlaid. Wauchope, Sk.

\section{WAUCHOPE}

$1906-1967$

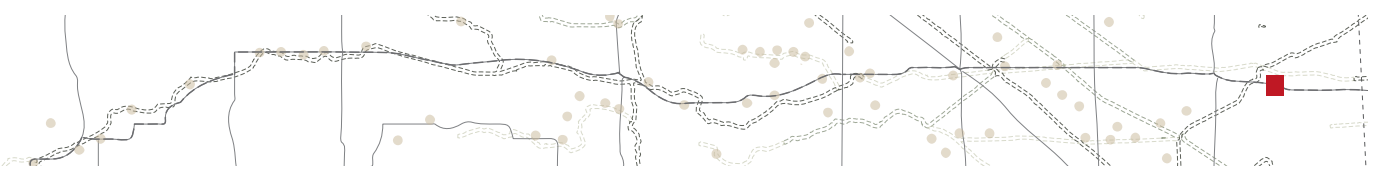

Fig 13.2 Location of Wauchope on Highway 13, Sk. 


\section{WAUCHOPE, SK}
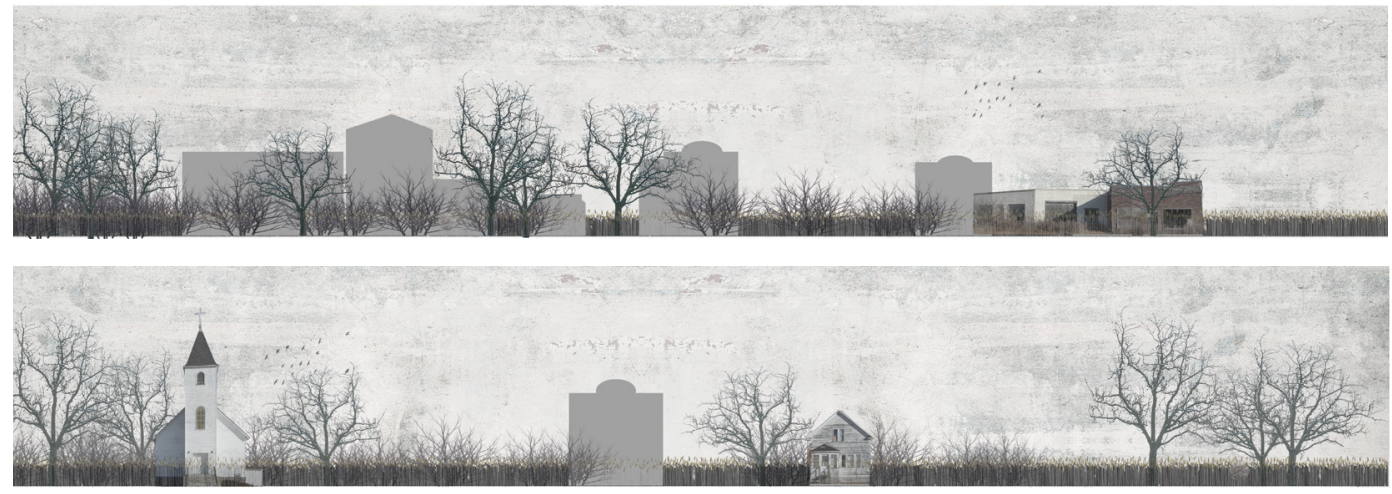

Fig 13.3 Street elevations, past and present conditions. Wauchope Sk.

$49.59531,-101.90617$

Peak Population: Unknown

Buildings / Structures: 5 as of 2018

Unkown at peak,

Grain Elevators: 1 Remaining - of 3

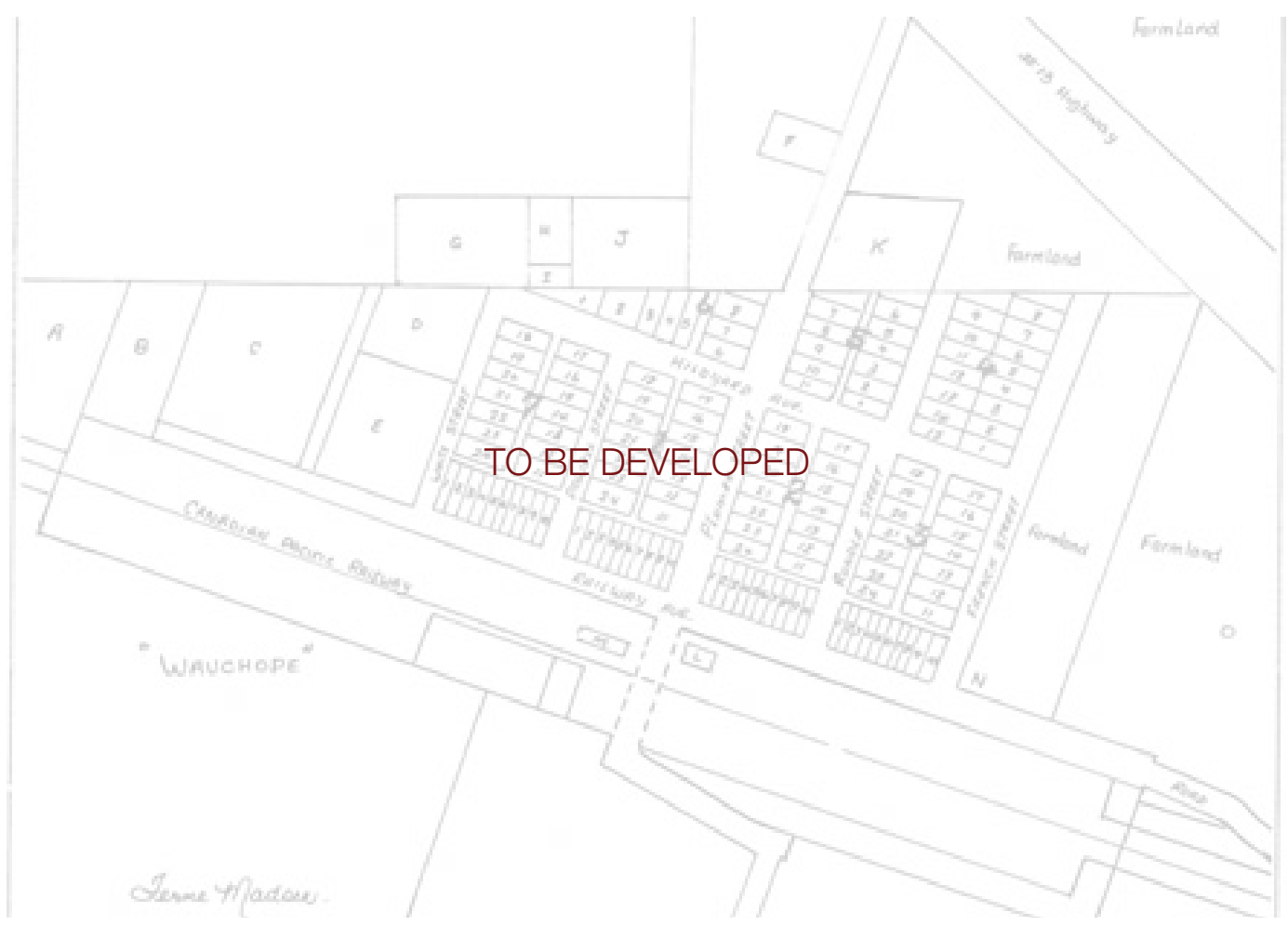

Fig 13.4 Site plan of Wauchope 


\section{WAUCHOPE, SK}

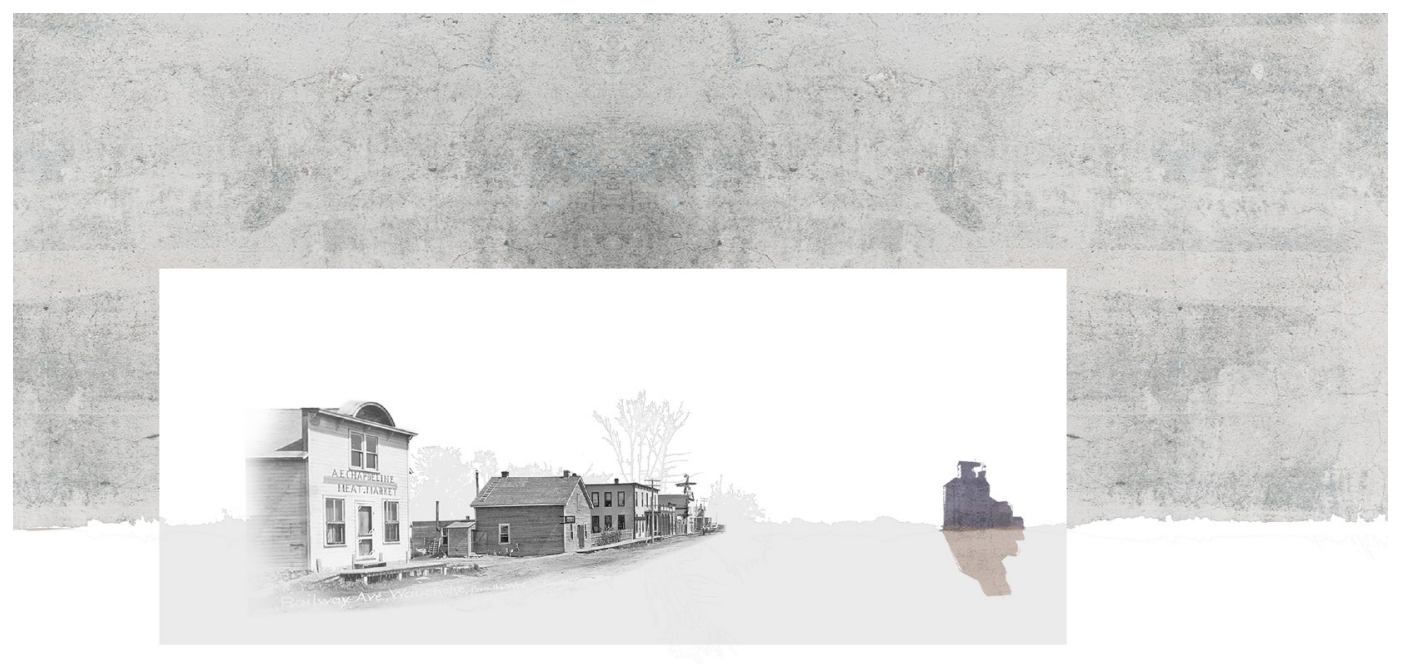

Fig 13.5 Cropped 360 view with past image overlaid. Wauchope, Sk.

"Wauchope in its early years was quite a business centre, serving territory halfway to Oxbow and Wawota. It had a privately owned elevator (Bergstrom's) as well as those of Western Canada, and later McCabe Co. There were two livery barns, two or more general stores, a bakery, butchershop, hotel, barbershop, and poolroom, two blacksmiths, a lumber yard, two or more implement agencies and a real estate promoter. There was a cobbler, old Mr. Rogg, who was too lame for active farming; and a dressmaker and tailoress, Mrs. Duez. One blacksmith shop was built by D. Martel, later sold to Arsene Sylvestre; the other was built by Mr. Dunbar. Mr. Gaudet began farming, then returned to his known trade of baker, while his wife and daughter added a little shop. A later blacksmith, Jean Boitteaux, had a silver medal to commemorate his participation in the wiring of the Eiffel Tower of Paris."

Wauchope / Parkman History Book, 20 


\section{WAUCHOPE, SK}

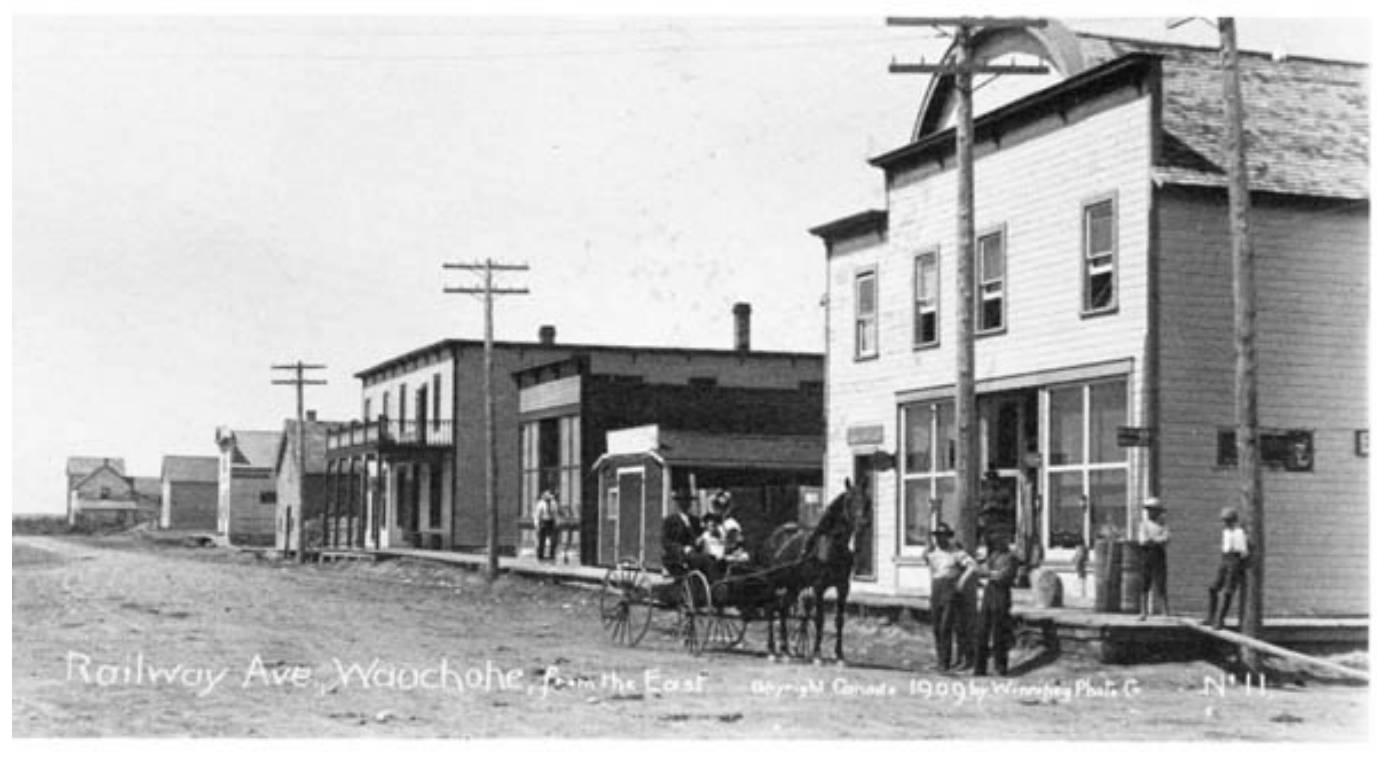

Fig 13.6 Historical photo of Wauchope, Sk.

"Then in the early 60's we decided to start a fast ball team, with not too many to choose from as the boys were very young. We named ourselves the 'Wauchope Colts'. It took a lot of practice and hard work, but the boys were willing and had a lot of heart. We started to jell in the middle 60's and never looked back - by 1969 we could play with the best. We traveled to Yorkton, Estevan, Brandon and Virden, Manitoba, Elcott and many other places - 98\% of the time we came home top winners. We had many tournament invitations from other towns that we were unable to attend. It gave us a nice feeling to know that Wauchope Colts were well recognized in the fast ball circuit."

Wauchope / Parkman History Book, 36 


\section{HISTORICAL PHOTOS}

UNAVAILABLE

\section{Pit}

KHEDIVE

$1916-2002$

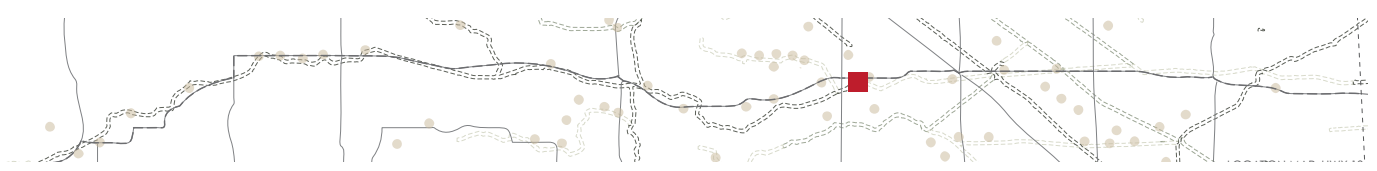

Fig 14.1 Location of Khedive along Highway 13, Sk. 


\section{KHEDIVE, SK}

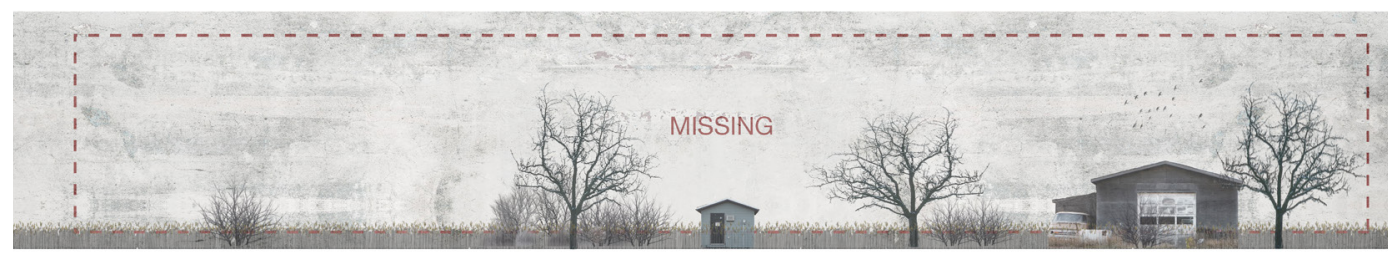

Fig 14.2 Street elevation of Khedive, Sk.

49.6213, -104.51969

Peak Population: 153

Buildings / Structures: 19 as of 2018

Unkown at peak,

Grain Elevators: 0 Remaining - of 3

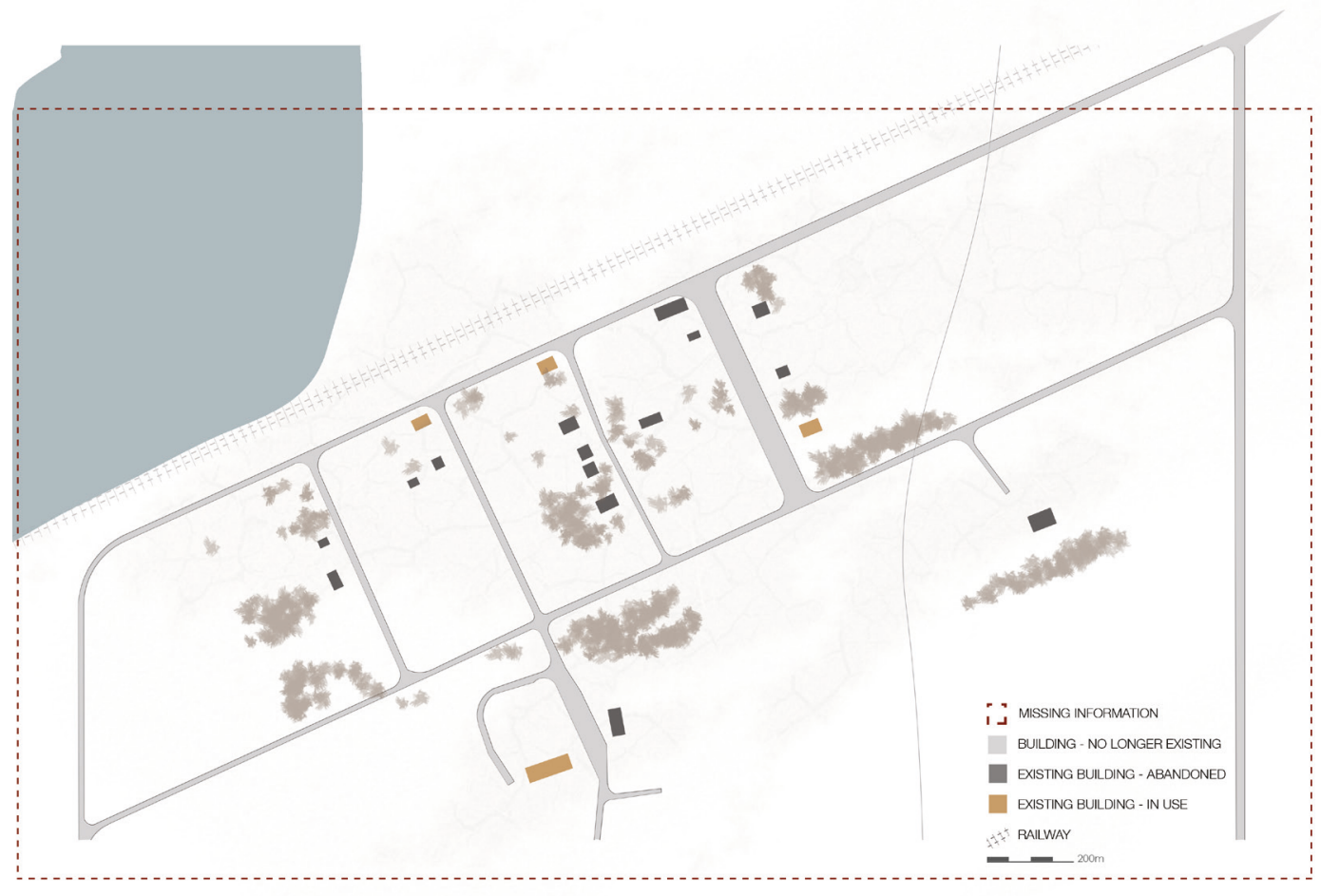

Fig 14.3 Site Plan of Khedive, Sk. 


\section{KHEDIVE, SK}

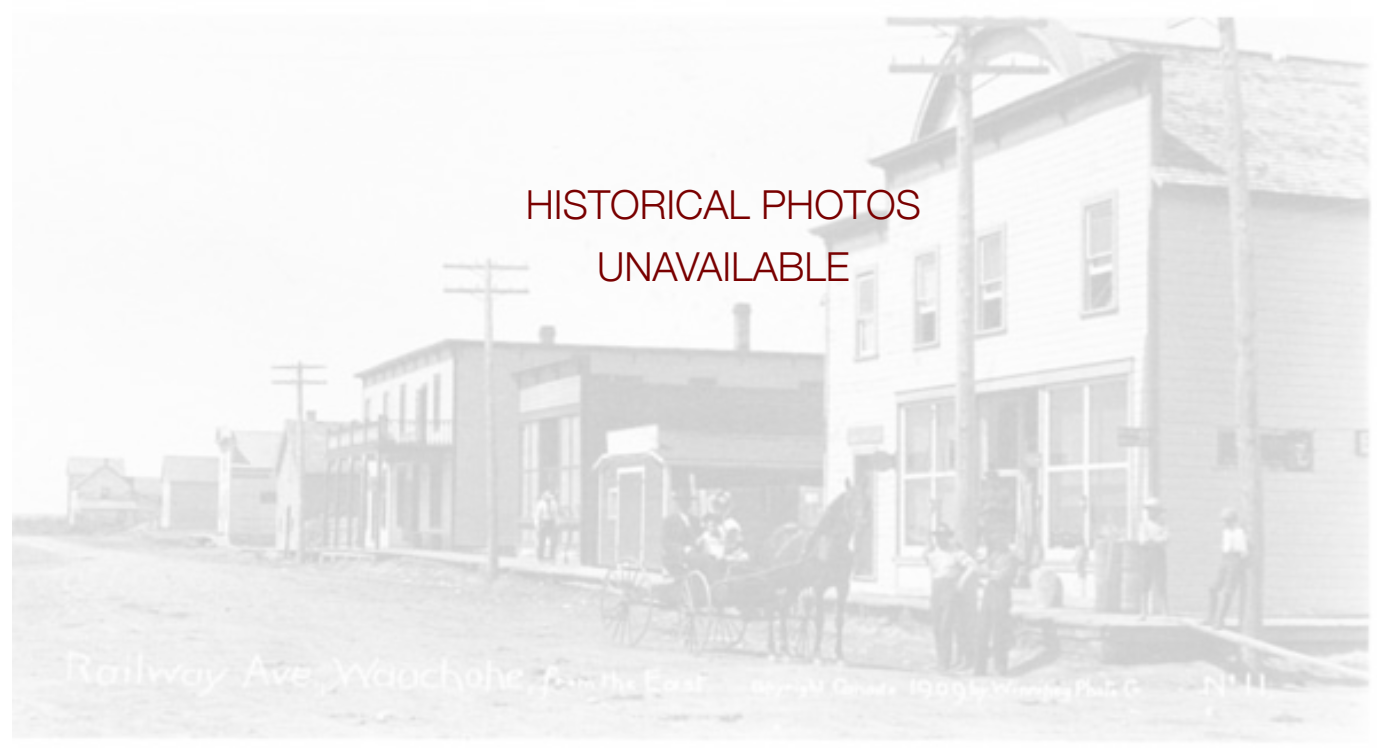

"Within a few years, Khedive had grown into a small, but thriving community. Three grain elevators, three churches, a school, a hotel, and a variety of businesses were established, serving the surrounding farming population.

For a number of years, Khedive station was a busy place, with two passenger trains daily and special return trip trains arranged on occasion to take residents to hockey games in Weyburn."

Our Towns, Saskatchewan Communities from Abbey to Zenon Park, 


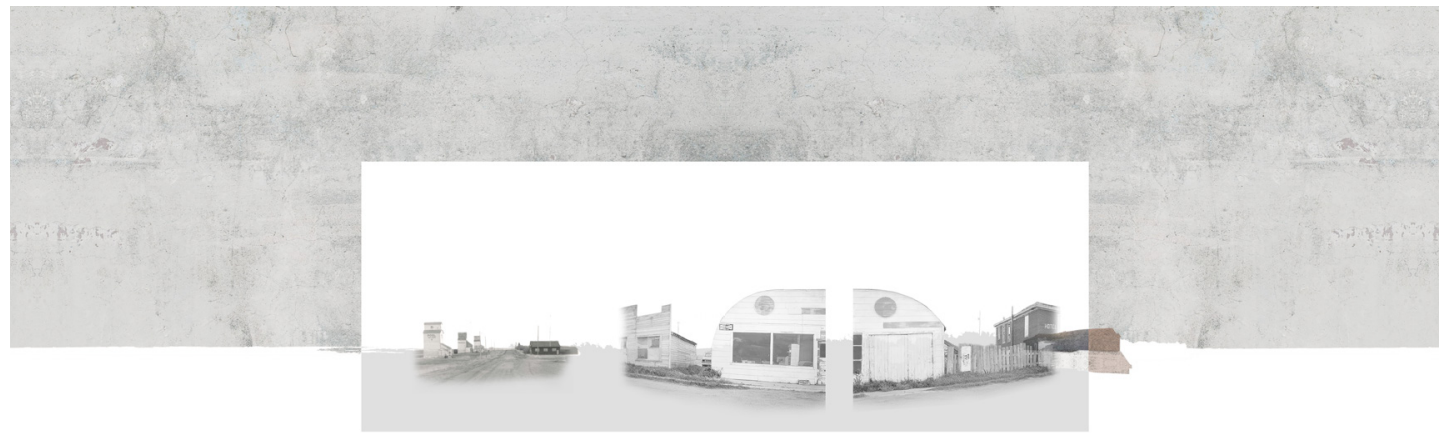

Fig 15.1360 view with past image overlaid, Melaval, Sk.

\section{MELAVAL}

$1914-1980$

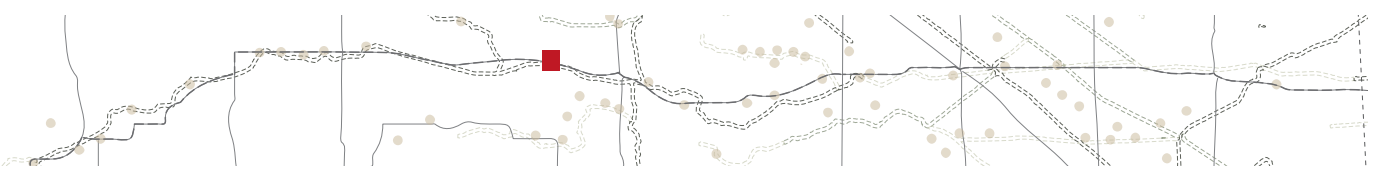

Fig 15.2 Location of Melaval along Highway 13, Sk. 


\section{MELAVAL, SK}

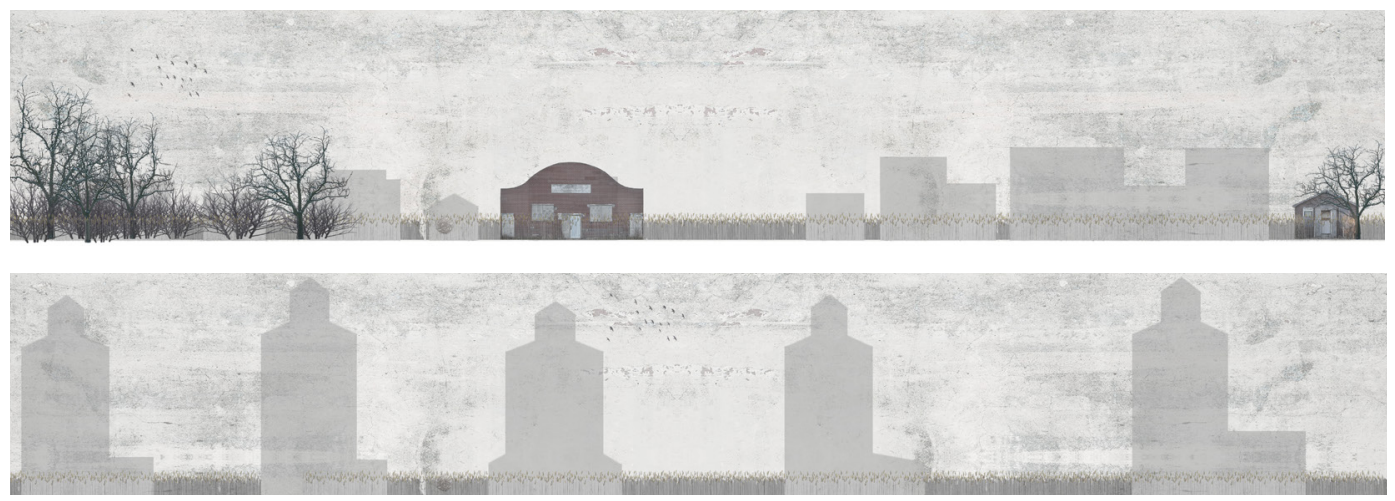

Fig 15.3 Street Elevations, Melaval, Sk.

49.69284, -106.45187

Peak Population: Unkown

Buildings / Structures: +/-15 as of 2018

$+/-100$ at peak,

Grain Elevators: 0 Remaining - of 6

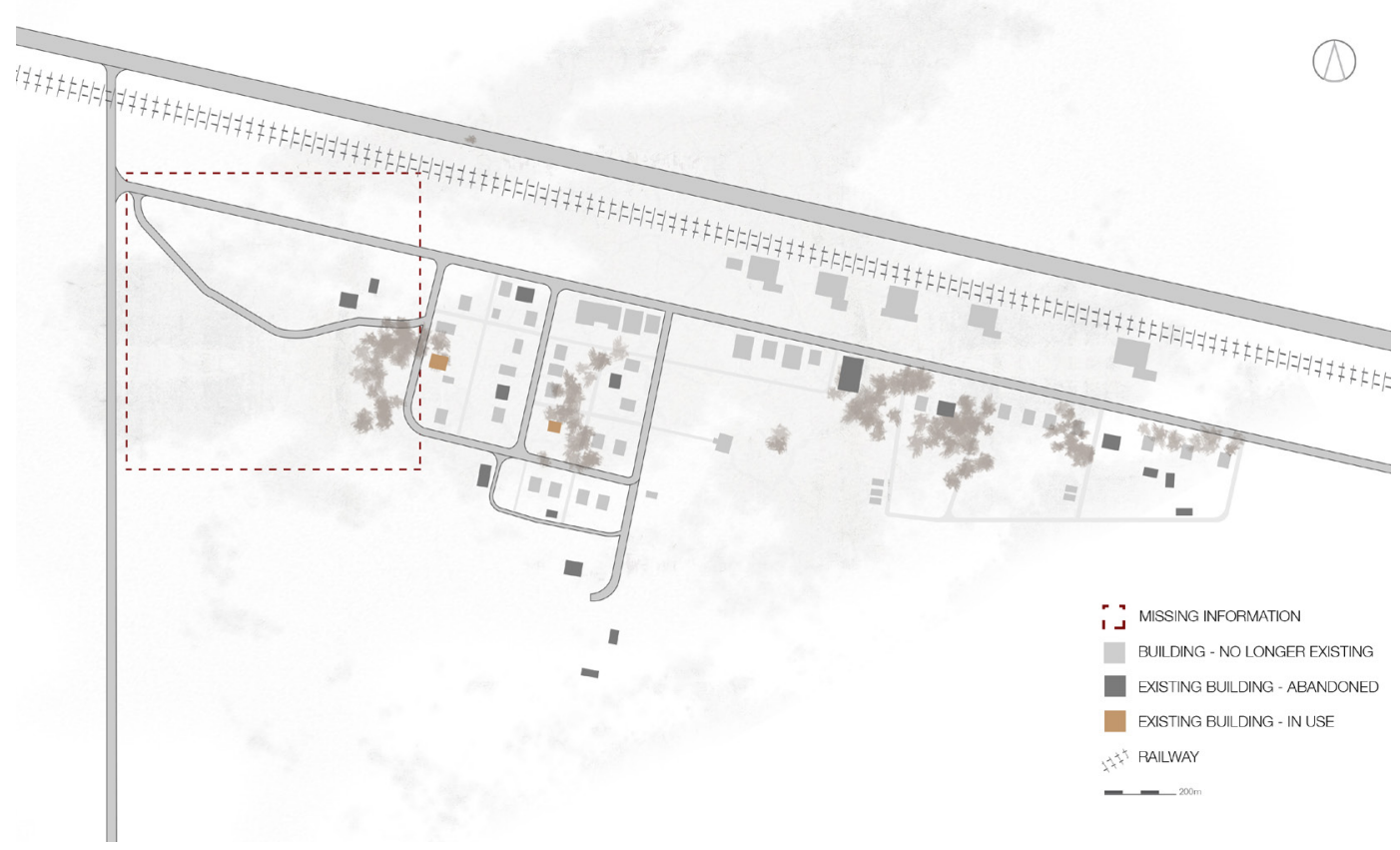

Fig 15.4 Site Plan, Melaval, Sk. 


\section{MELAVAL, SK}

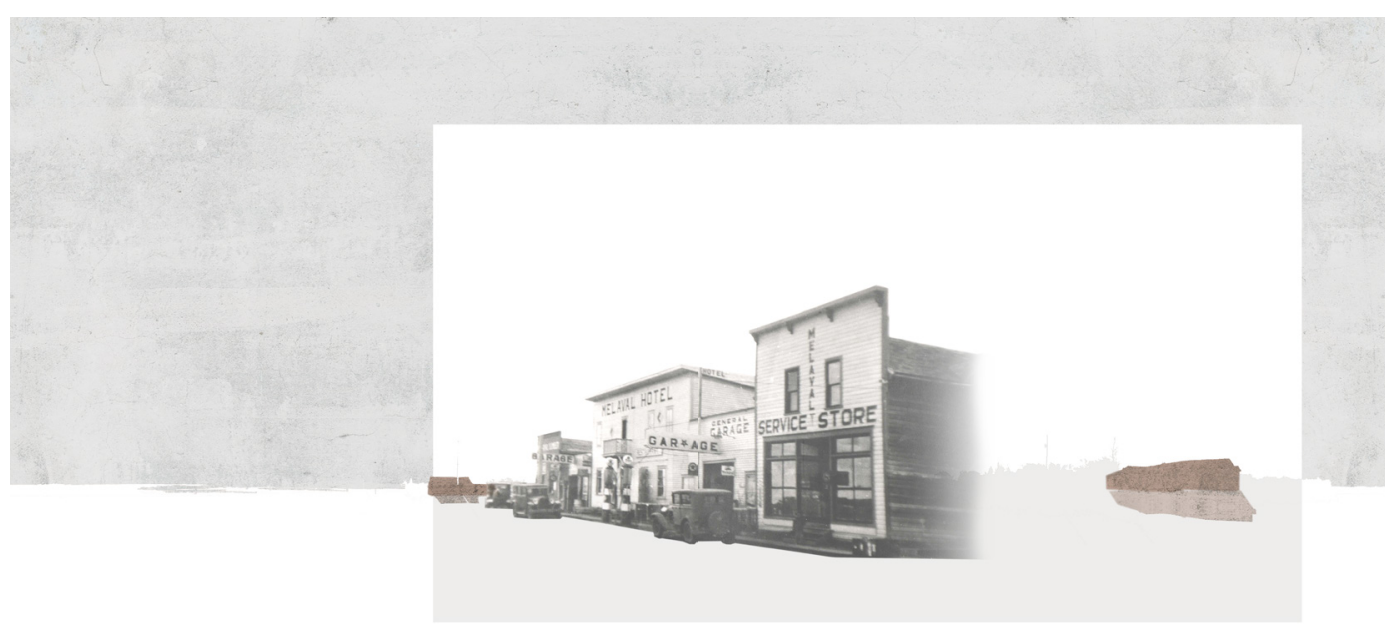

Fig 15.5 Cropped 360 view with past image overlaid, Melaval, Sk.

"Melaval "was probably 'pretty happening' during the 1920s, the '30s and the '40s," said Brekke Massé, administrator of the RM of Wood River. Lee Harding, who grew up on a nearby farm, figures the 1950s was when the town peaked. "At one time, the community had six elevators in operation," he says.

Sadly, Melaval shrank. The K-8 school closed in 1970 and the building was moved a decade later. The elevators closed and several were burned to keep them from becoming derelict, says Harding. He adds "there's just about nothing left" save for a handful of homes."

Will Chabun, Regina Leader Post, 14 Sept. 2016 


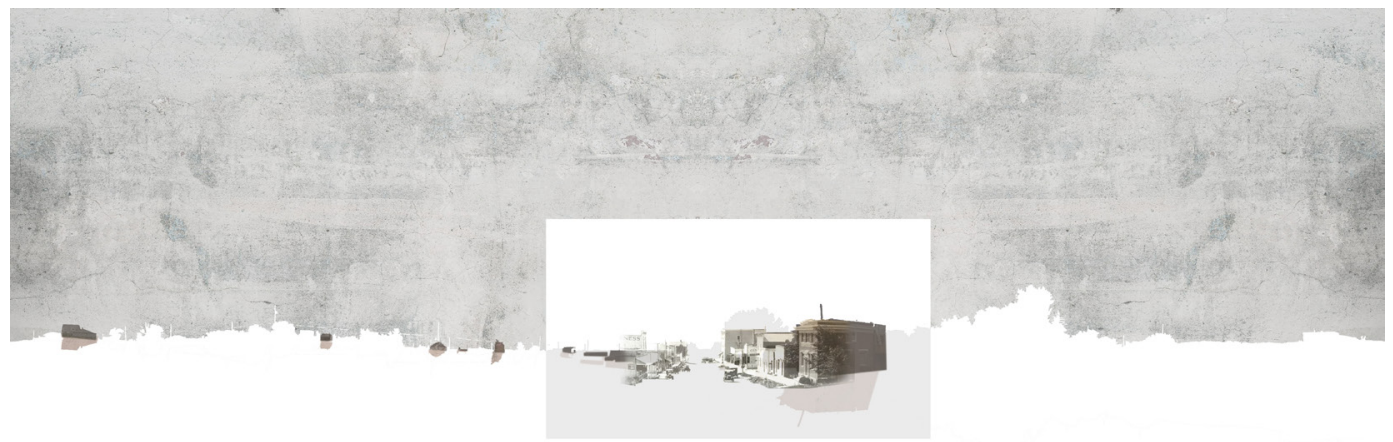

Fig 16.1 360 view wit past image overlaid, Admiral, Sk.

\section{ADMIRAL}

$1914-2006$

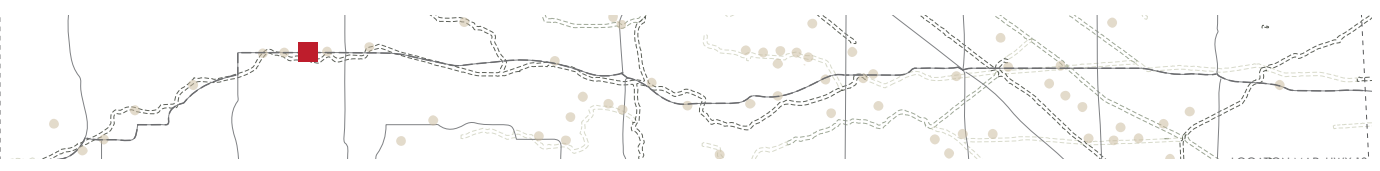

Fig 16.2 Location of Admiral along Highway 13, Sk. 


\section{ADMIRAL, SK}
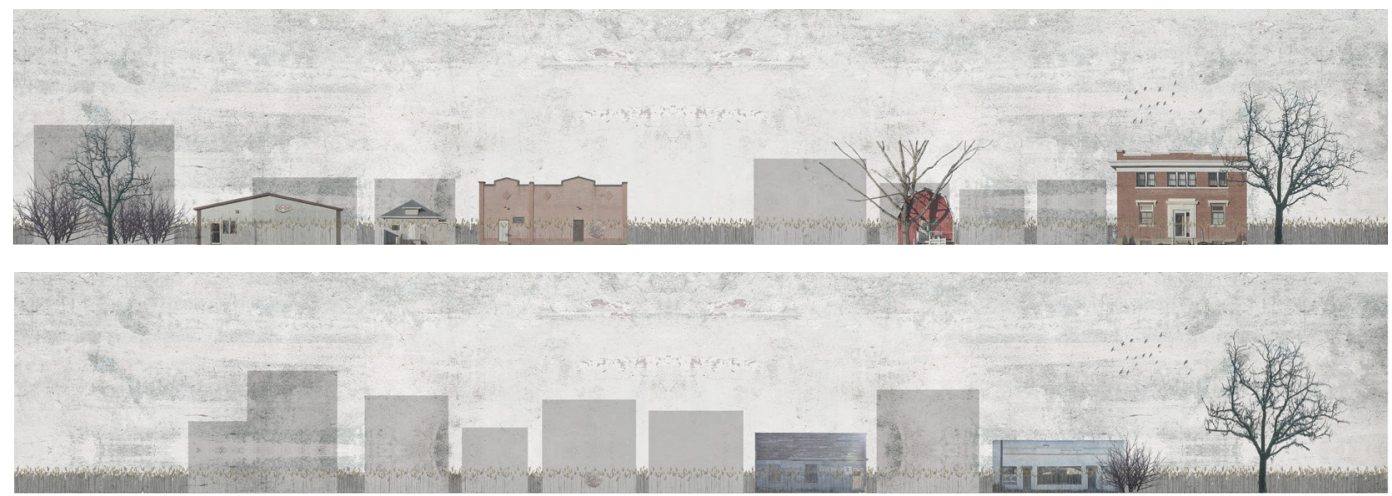

Fig 16.3 Street Elevations, Admiral, Sk.

$49.71411,-108.00821$

Peak Population: 250

Buildings / Structures: +/-25 as of 2018

$+/-200$ at peak,

Grain Elevators: 1 Remaining - of 5

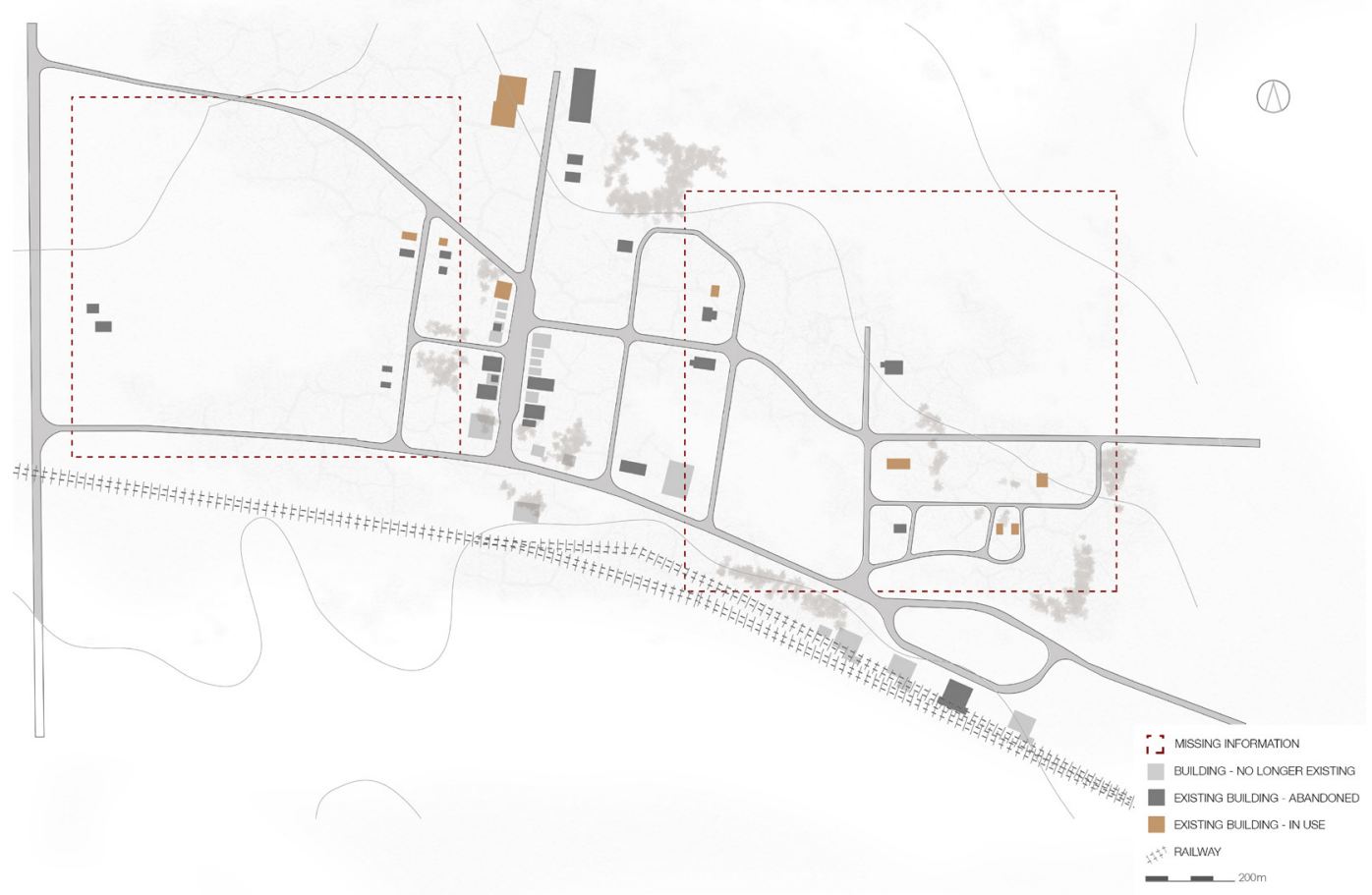

Fig 16.4 Site Plan, Admiral, Sk. 


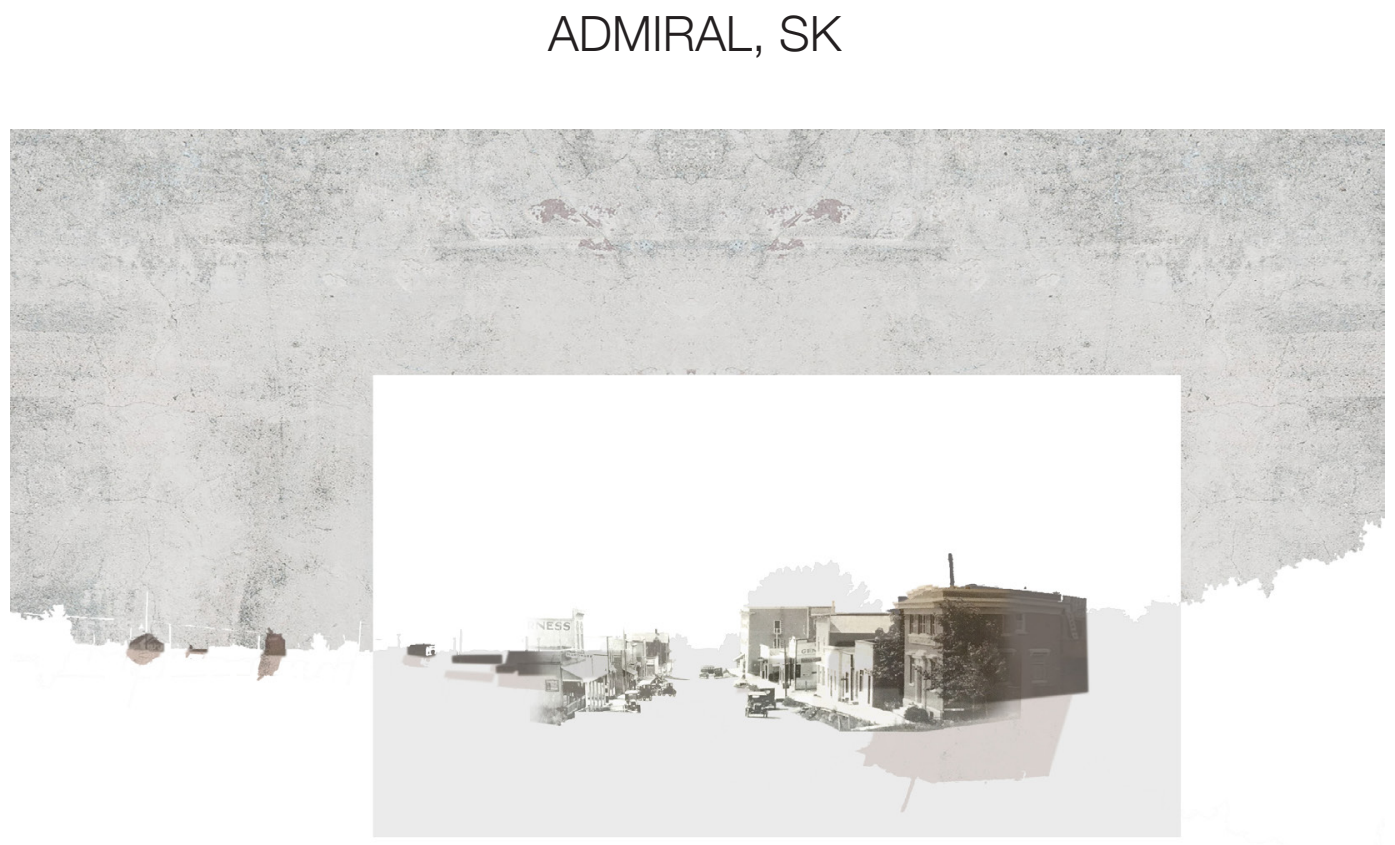

Fig 16.5 Cropped 360 view with past image overlaid, Admiral, Sk.

"Settlers came to the area in the early 1900s and a rural post office was founded as Blairville in 1911. The Canadian Pacific Railroad arrived two years later, in 1913. In 1914 the village was officially incorporated as "Admiral," and in keeping with the nautical theme, the streets were reportedly named for historic naval figures-Drake Street, Frobisher Street, and Nelson Avenue, for instance, as well as Revenge Avenue."

"Vanishing Hamlet: Admiral, Saskatchewan" Ghosts of North America 


\section{ADMIRAL, SK}

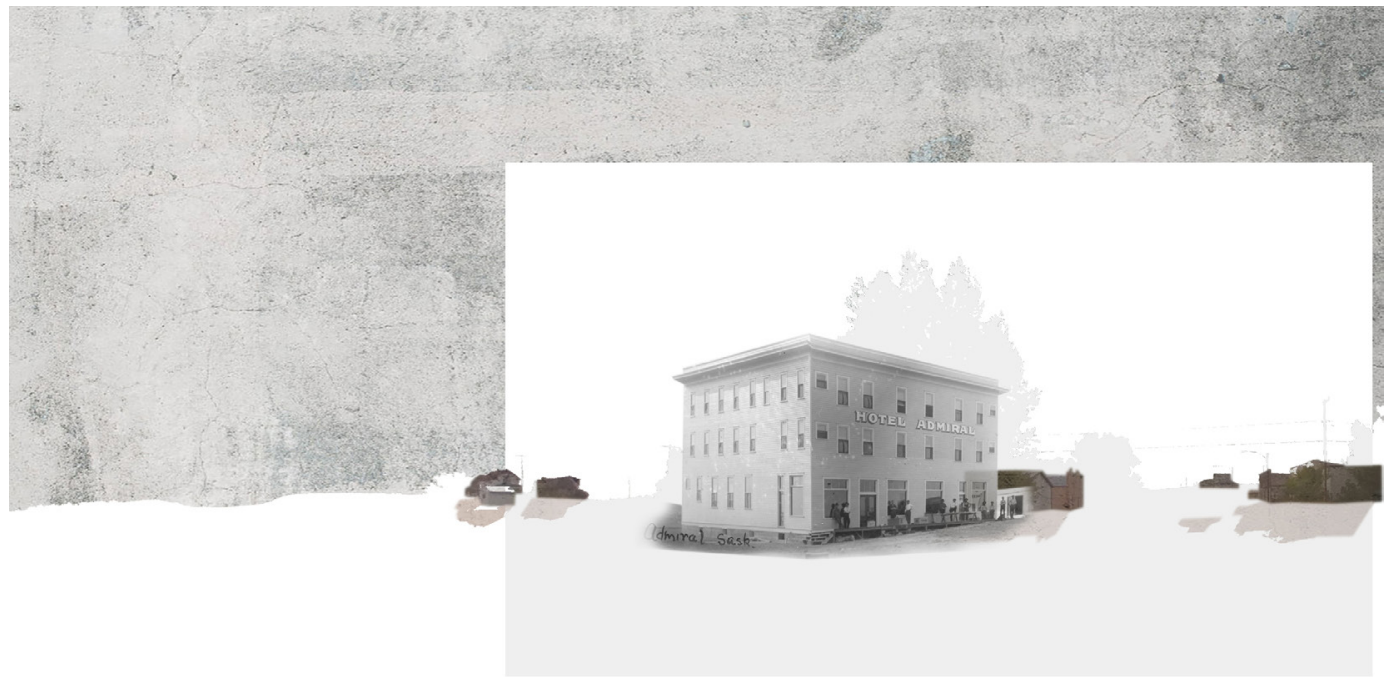

Fig 16.6 Cropped 360 view with past image overlaid, Admiral, Sk.

MORE STORIES NEEDED 


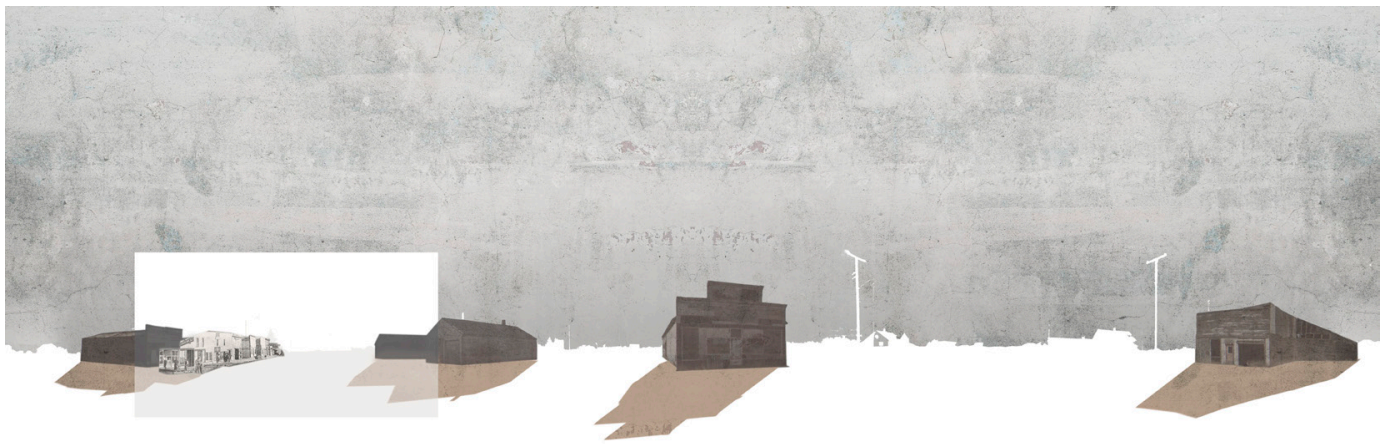

Fig 17.1 360 view with past image overlaid, Robsart, Sk.

\section{ROBSART}

$1910-2002$

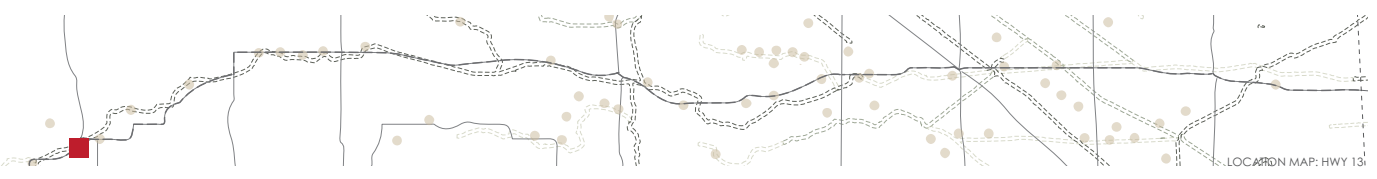

Fig 17.2 Location of Robsart along Highway 13, Sk. 


\section{ROBSART, SK}
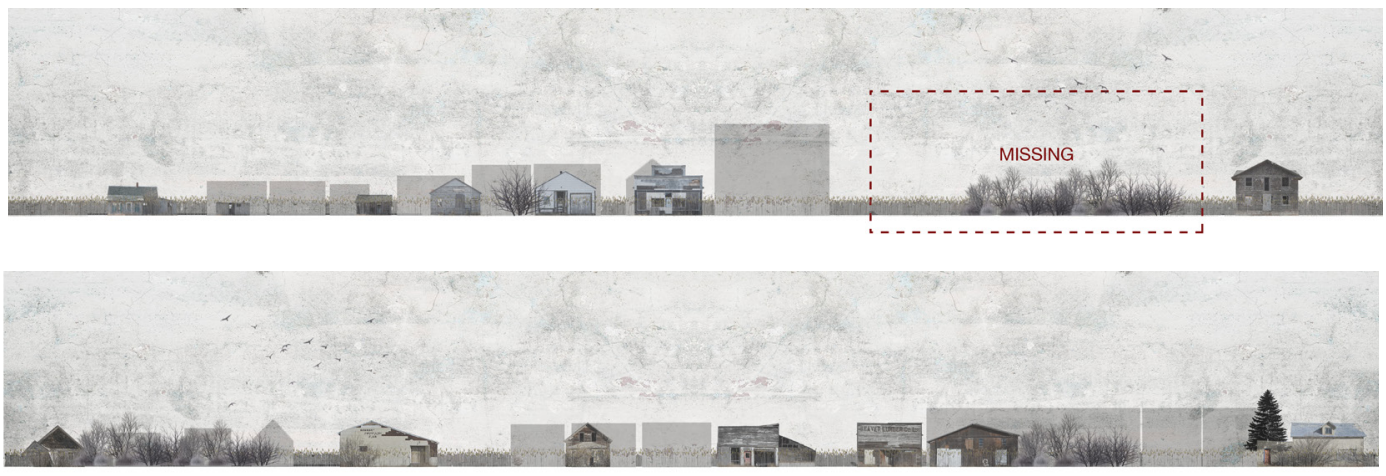

Fig 17.3 Street Elevations, Robsart, Sk.

49.3728, -109.28235

Peak Population: 350

Buildings / Structures: +/-20 as of 2018

$$
\text { +/- } 300 \text { at peak, }
$$

Grain Elevators: 0 Remaining - of Several

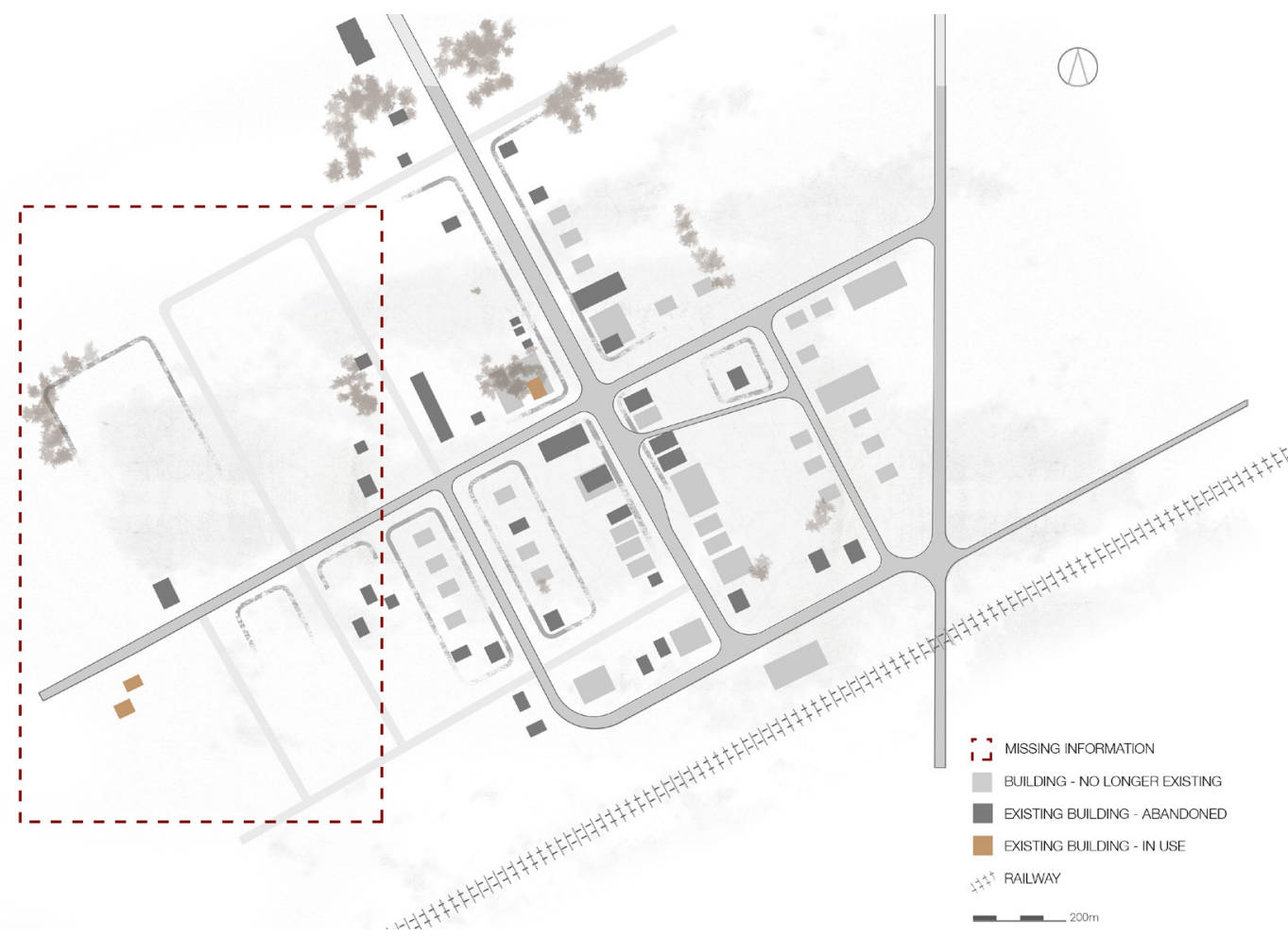

Fig 17.4 Site Plan, Robsart, Sk. 


\section{ROBSART, SK}

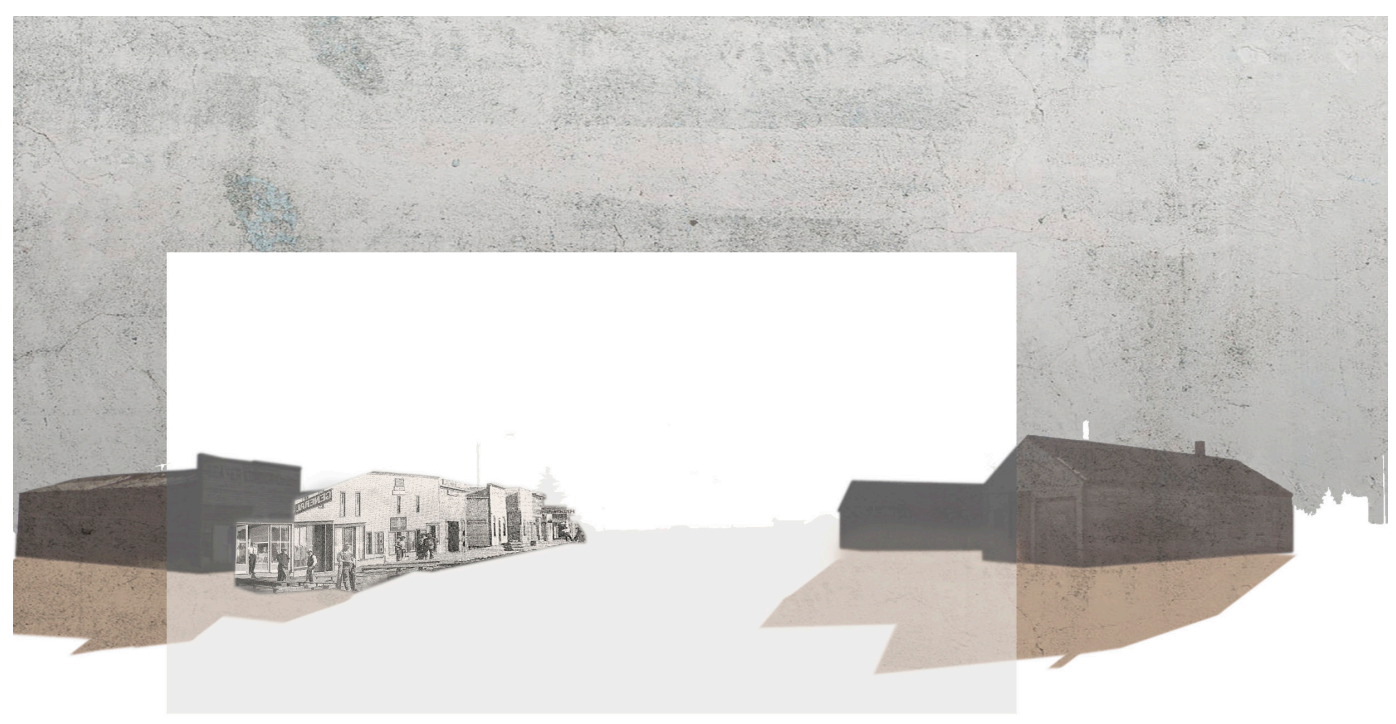

Fig 17.5 Cropped 360 view with past image overlaid, Robsart, Sk.

"With the arrival of the railroad in 1914, Robert was a land of promise. In fact, postcards of the day hailed the pioneer community as, "The town with a bright future." Every week, locals observed, fresh businesses were optimistically opening their doors. There were new hotels, cafes, livery barns, grain elevators and a bank. There was even a photography store run by Uncle John Asplund."

"Robsart," Saskatchewan Ghost Towns

"Battling hurricane-like winds, Joe and Gordon struggled to find some large poles and propped them against the house, three on the outside and two inside. However, it was clear that the storm was winning the battle and the house began to sag under the force of the wind. Hattie nailed quilts and blankets across the doorway to shut out the draft, but it did little to keep out the cold. 'The men brought in all the fuel they could, and we had two ripping fires on and the stoves were red hot, yet it was so cold we could hardly tell there was any fire,' Hattie remembers. The blizzard lasted three days. ... When the storm finally subsided, the house was still standing, albeit it askew. Joe straightened it out with a jack."

$\sim$ Ghost Town Stories of the Red Coat Trail, 81 


\section{ROBSART, SK}

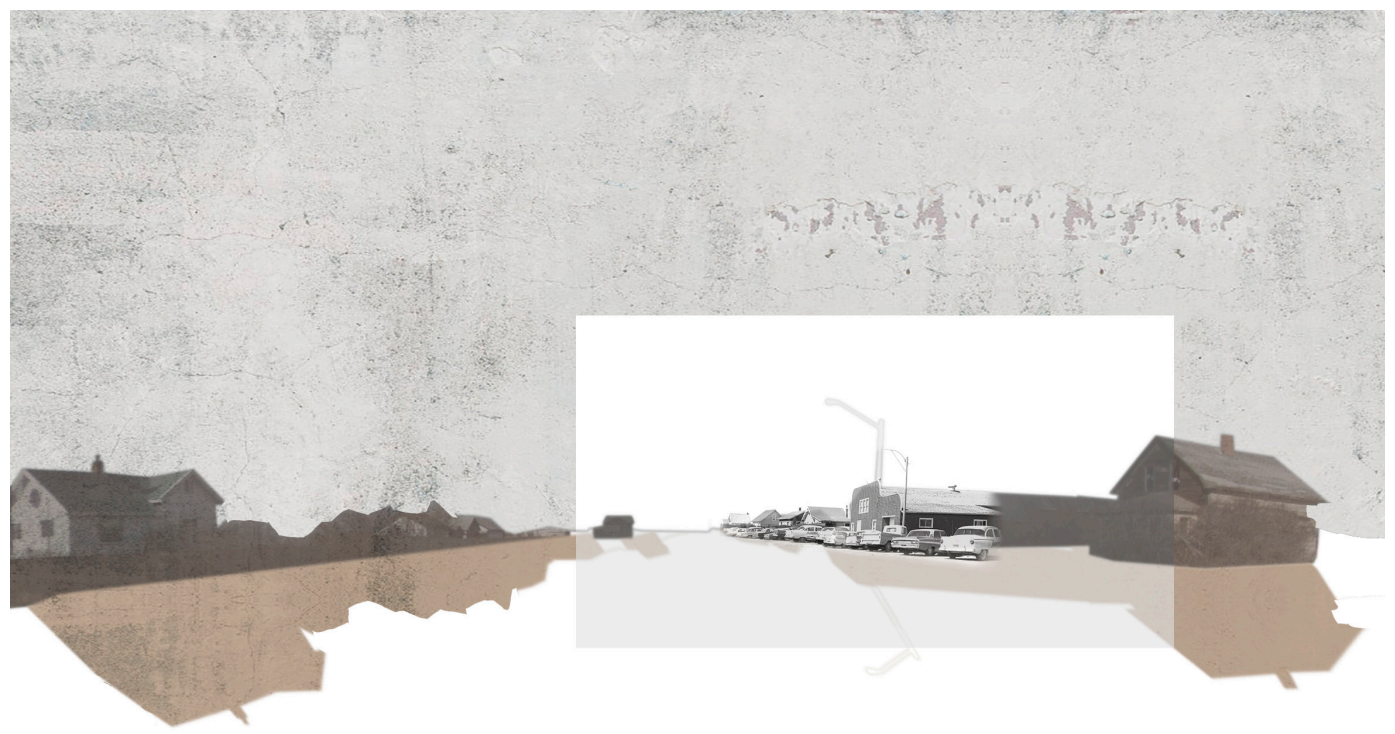

Fig 17.6 Cropped 360 view with past image overlaid, Robsart, Sk.

"Wandering about Robsart, we're immediately taken aback. It just feels so lonely, spooky, lost, forgotten. I could go on. Peering into some buildings, one can see lots of stuff left behind. It's almost as though people just up and left one day, taking little with them."

"A Slice of Robsart," Off The Beaten Path

Here's to Robsart, it's still here yet, No store, no hotel, a well with a jet.

The main street still stretching, not much in your way.

When you put it together, there is nothing more, No hustle, no bustle, no rumble, no roar.

It's as dead as a doornail, it's as old as the hills, No fun, no excitement, no jolly old thrills.

But still we did love it, though far we may roam, For Robsart is Robsart, and Robsart was home.

$\sim$ Poem by Archie Smiley, Ghost Town Stories of the Red Coat Trail, 82 


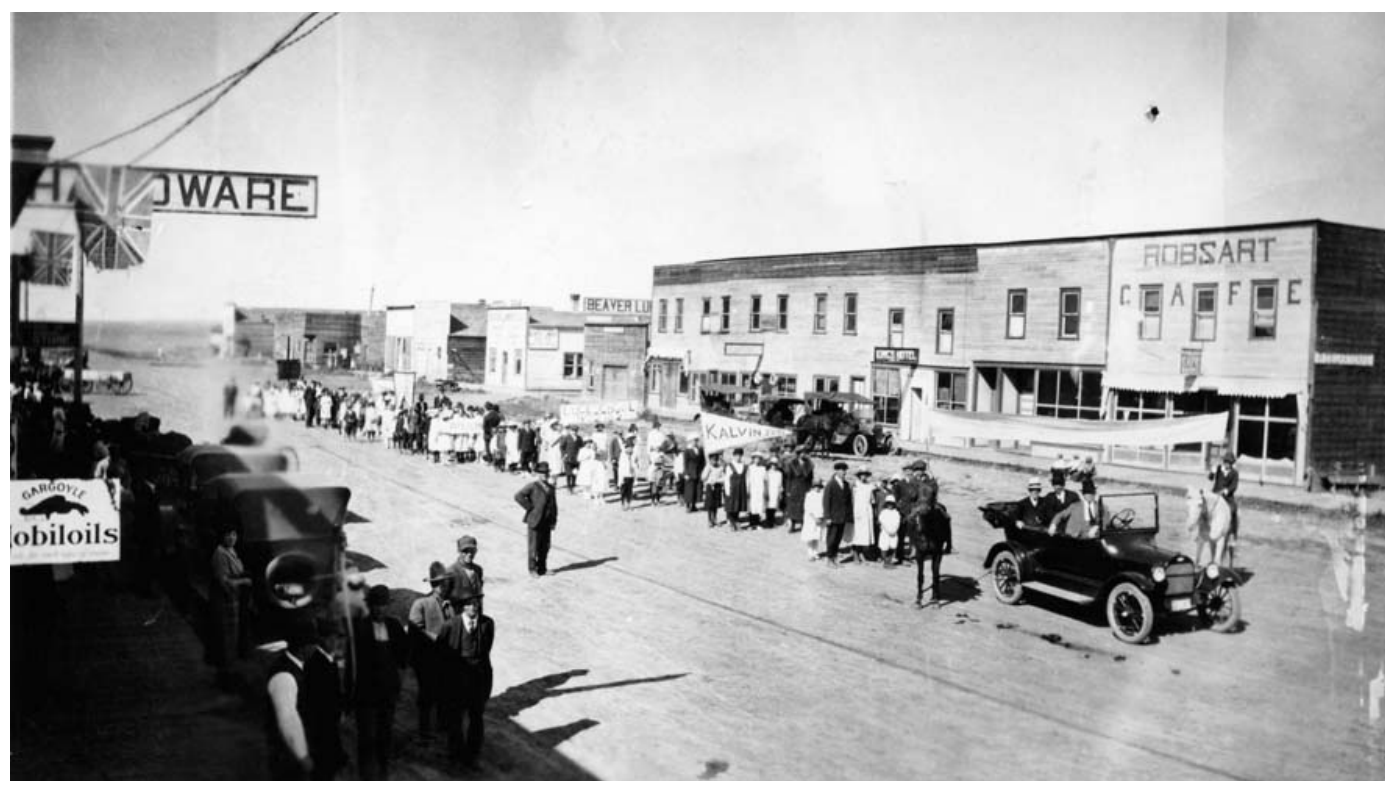

Fig 17.7 Historical photo, Robsart, Sk.

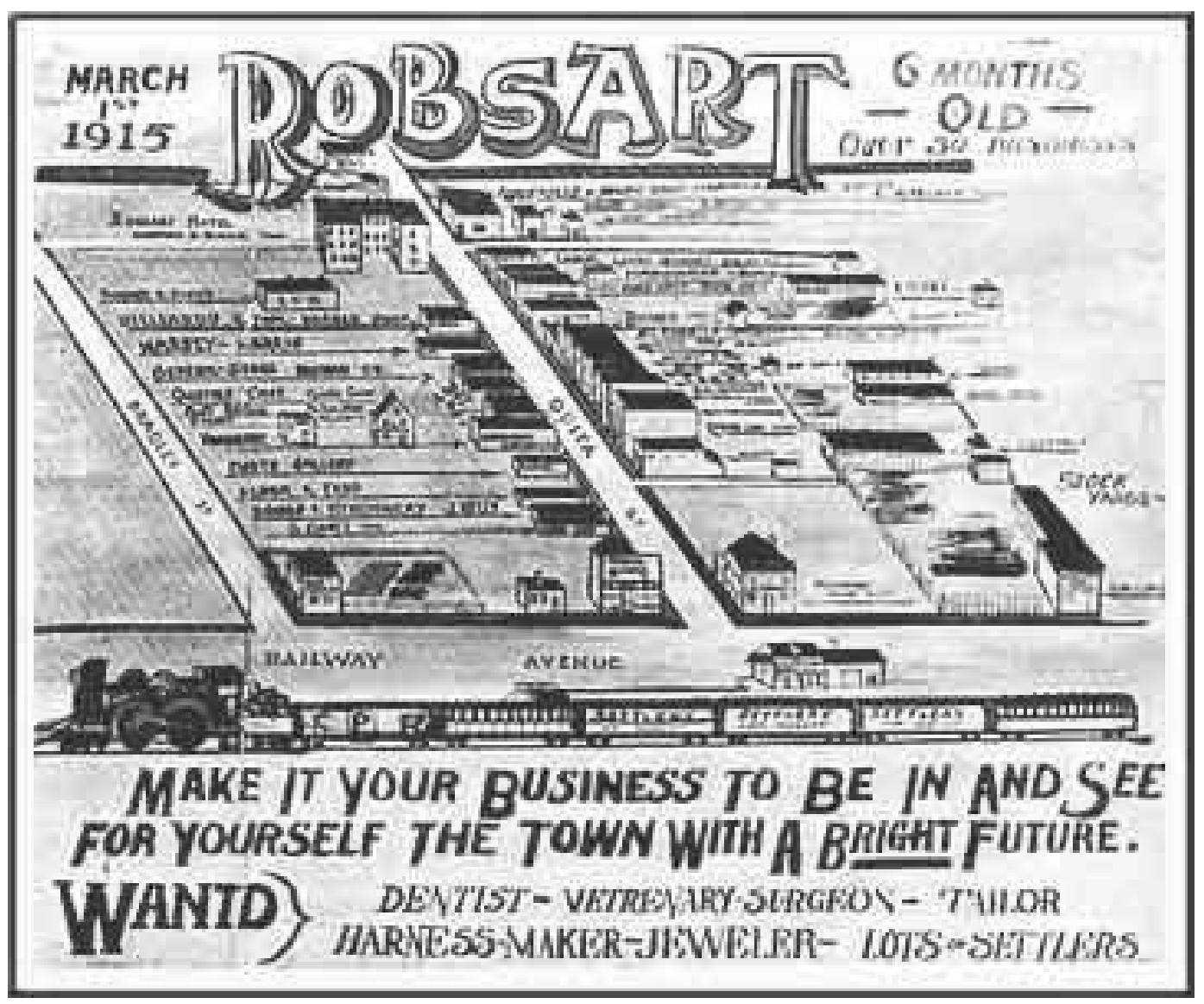

Fig 17.8 Site map from 1915, Robsart, Sk. 


\section{Appendix 01 \\ Highway 13 Experience}

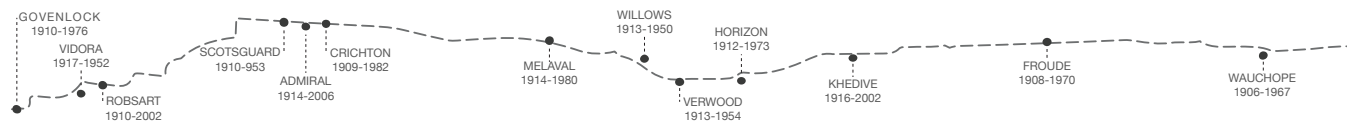

A collection of still frames from a time-lapse video of the entirety of Saskatchewan's portion of Highway 13 - "Red Coat Trail." Driving from east to west, the 670 kilometres of patched blacktop was captured in a October, 2018, by author, and sped into a twenty minute atmospheric video. With a still frame at every two minutes of that video, along with the location of the vehicle at that time, this collection is meant to portray the current state of emptiness of a once thriving area.

Fig 18.0 Documented Towns along Saskatchewan's Highway 13 


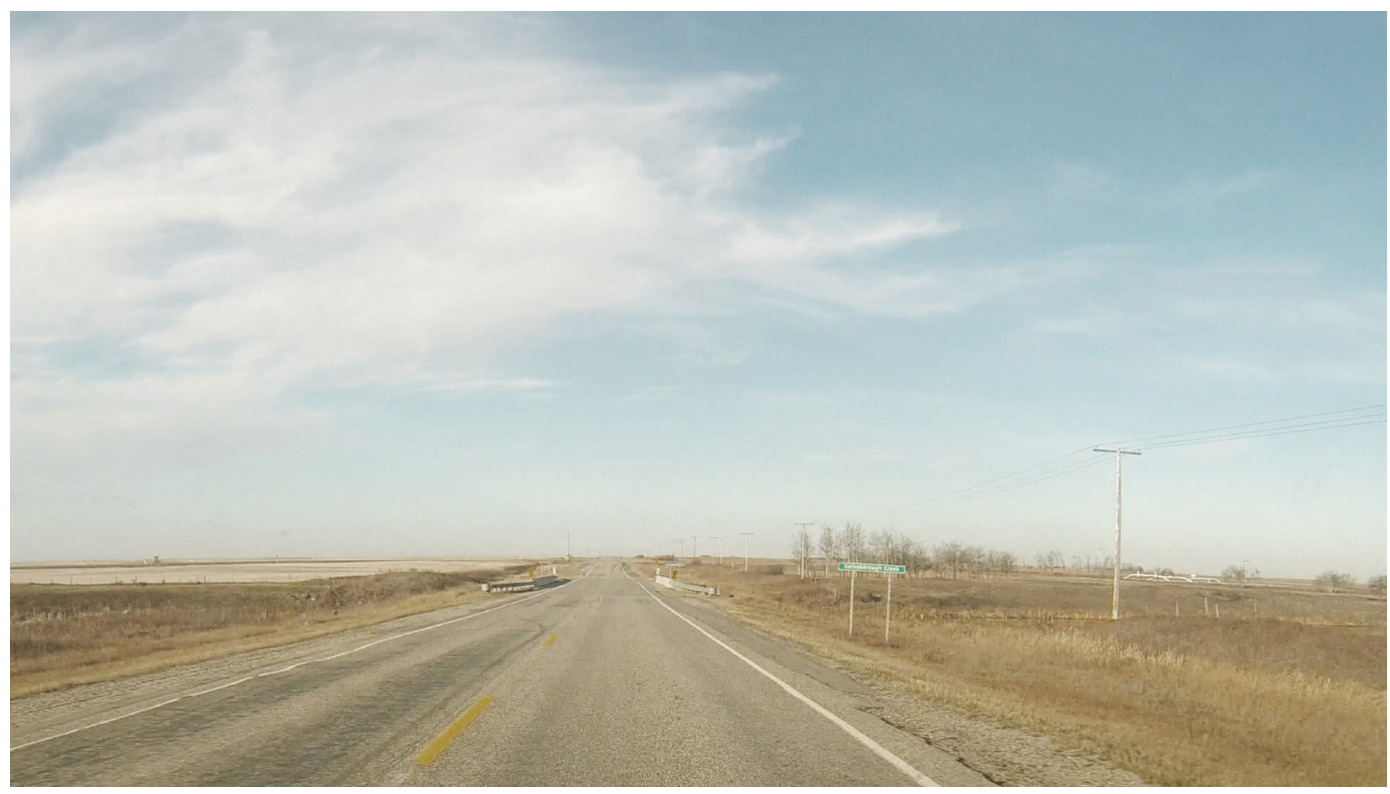

Fig 18.1 Minute 00 of Highway 13 Time-lapse. 

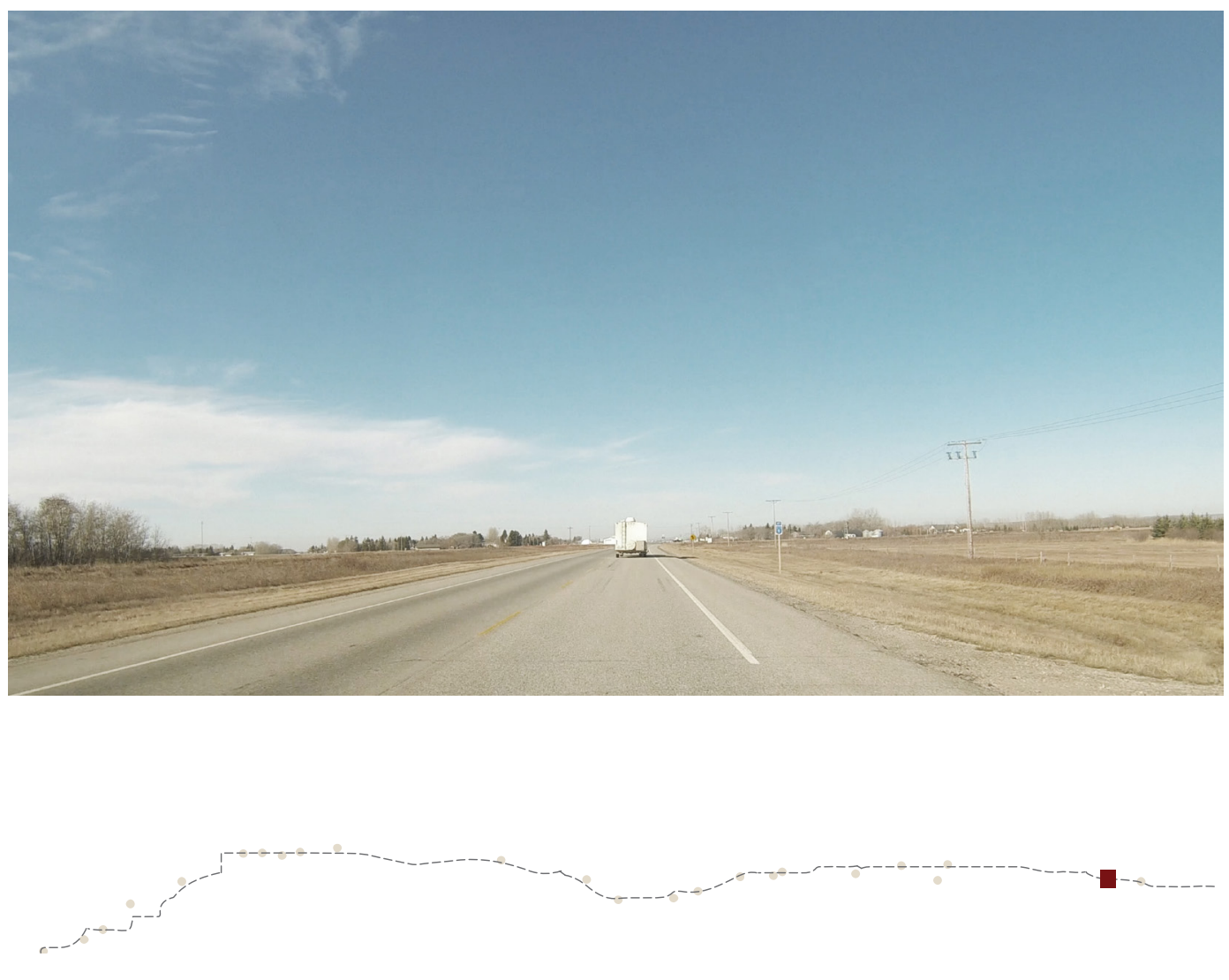

Fig 18.2 Minute 02 of Highway 13 Time-lapse. 

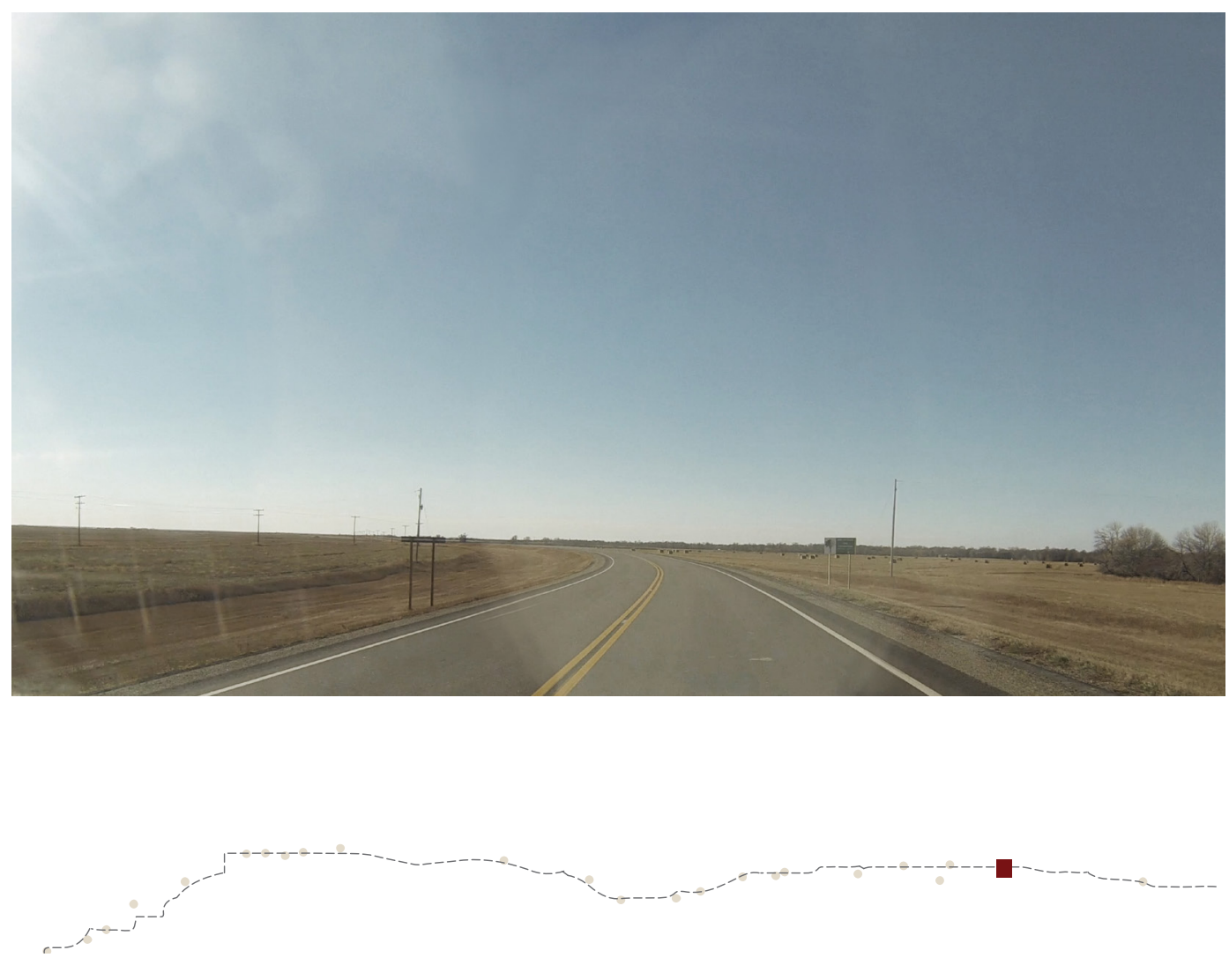

Fig 18.3 Minute 04 of Highway 13 Time-lapse. 

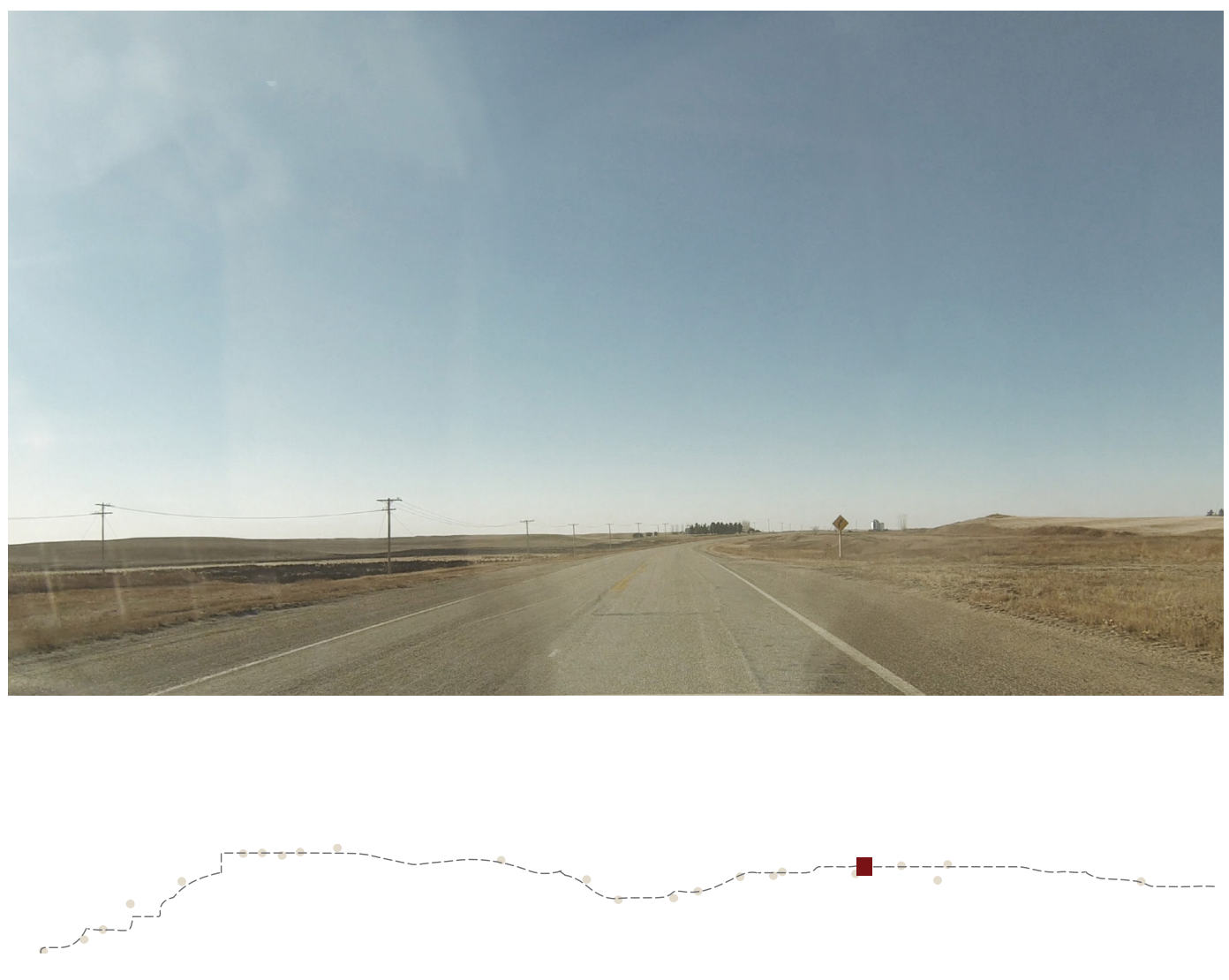

Fig 18.4 Minute 06 of Highway 13 Time-lapse. 


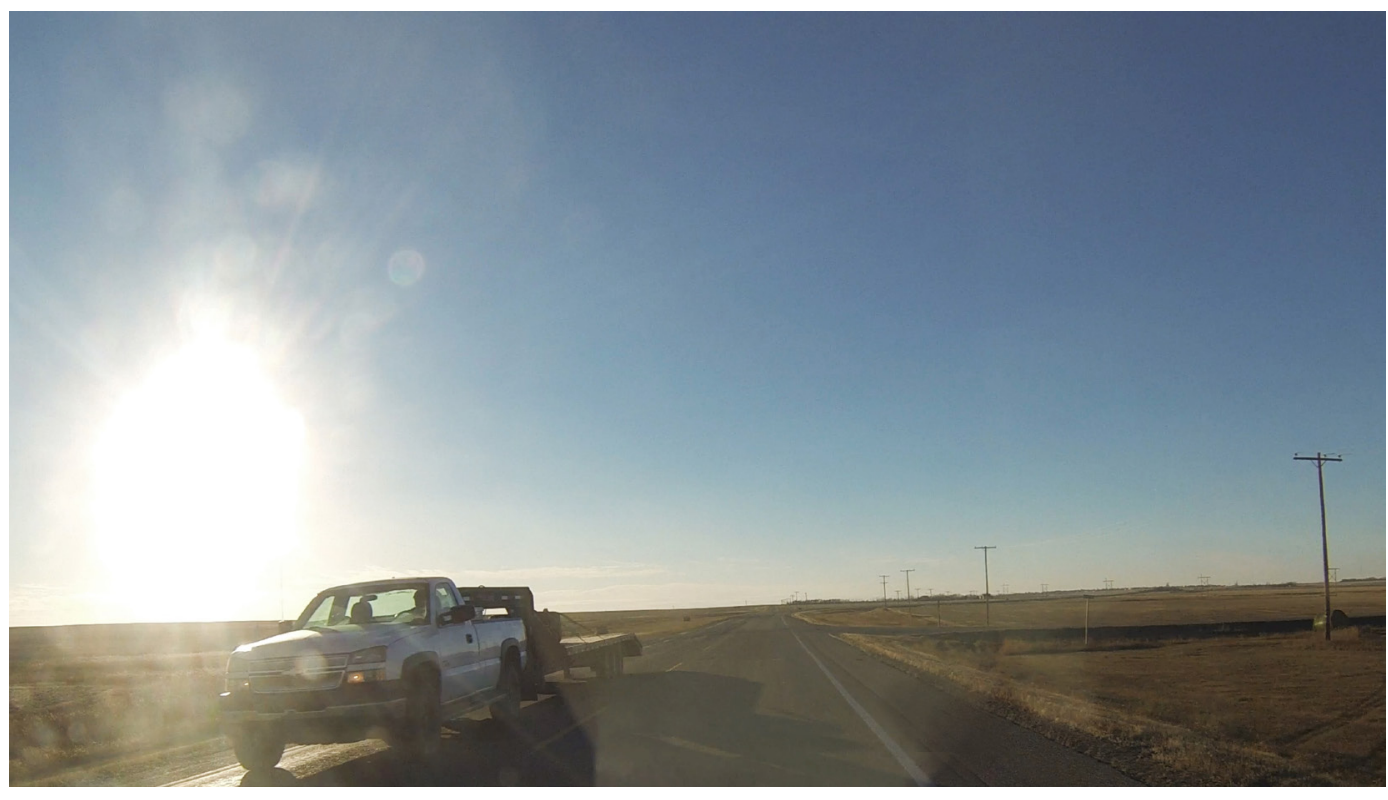

Fig 18.5 Minute 08 of Highway 13 Time-lapse. 

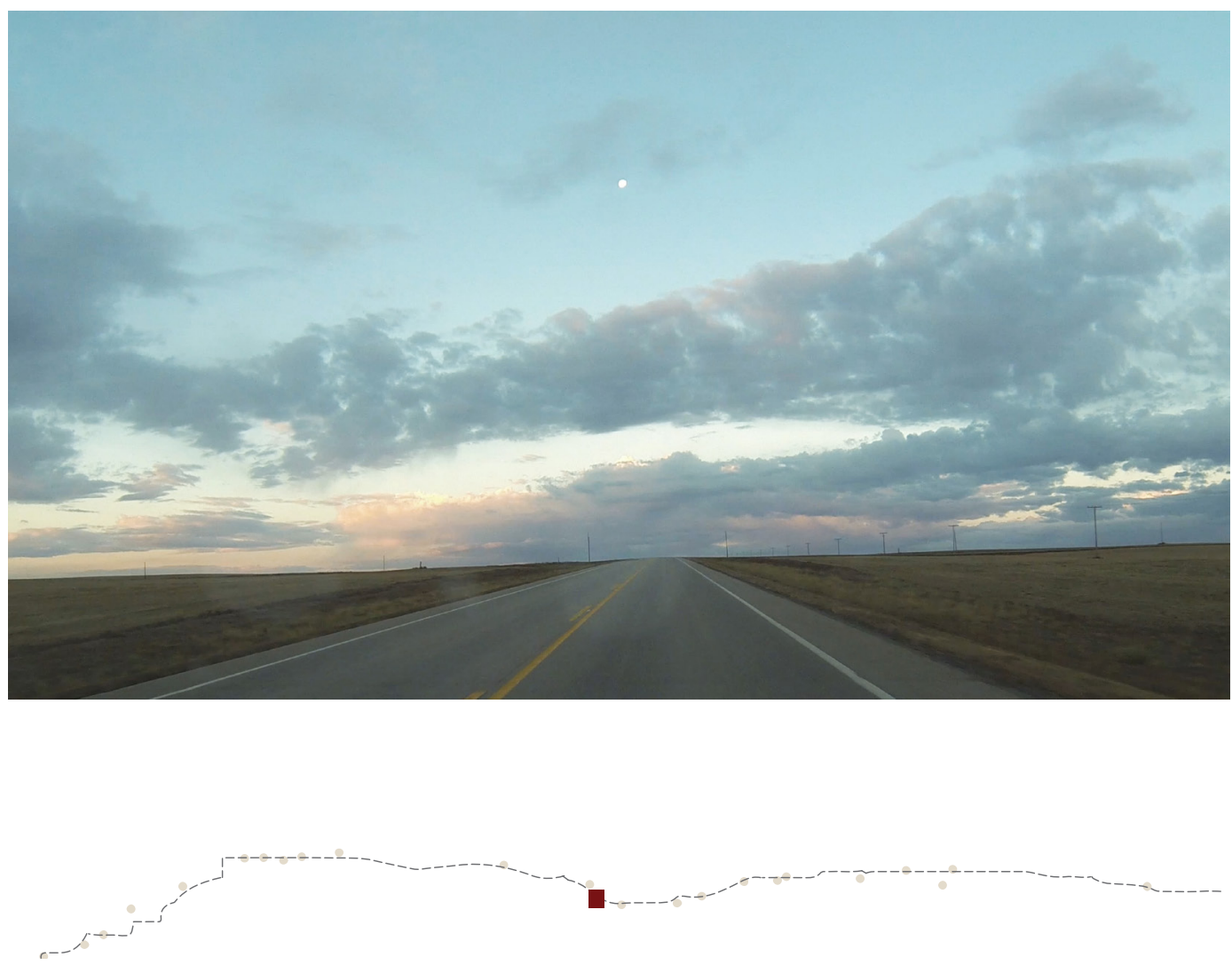

Fig 18.6 Minute 10 of Highway 13 Time-lapse. 

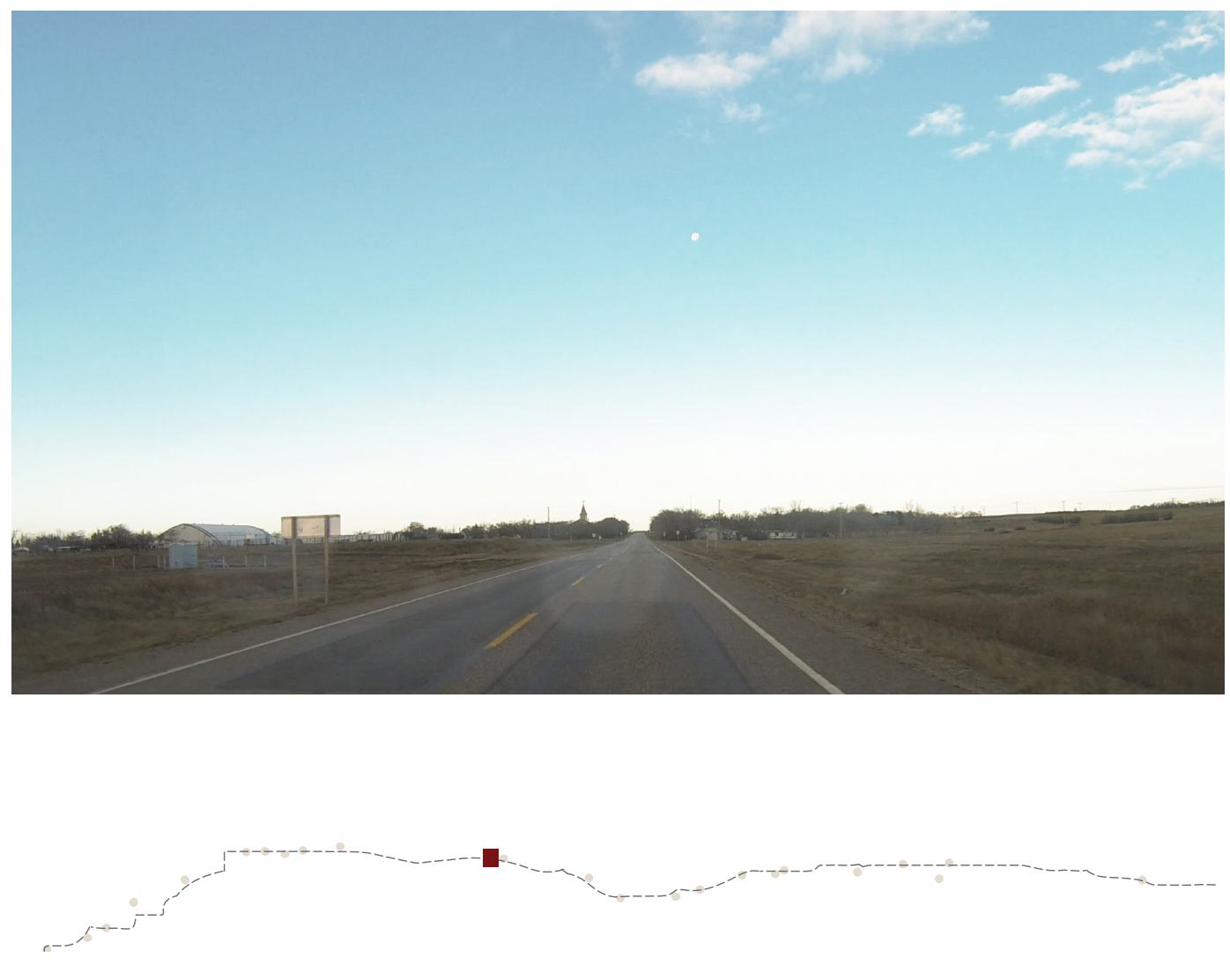

Fig 18.7 Minute 12 of Highway 13 Time-lapse. 


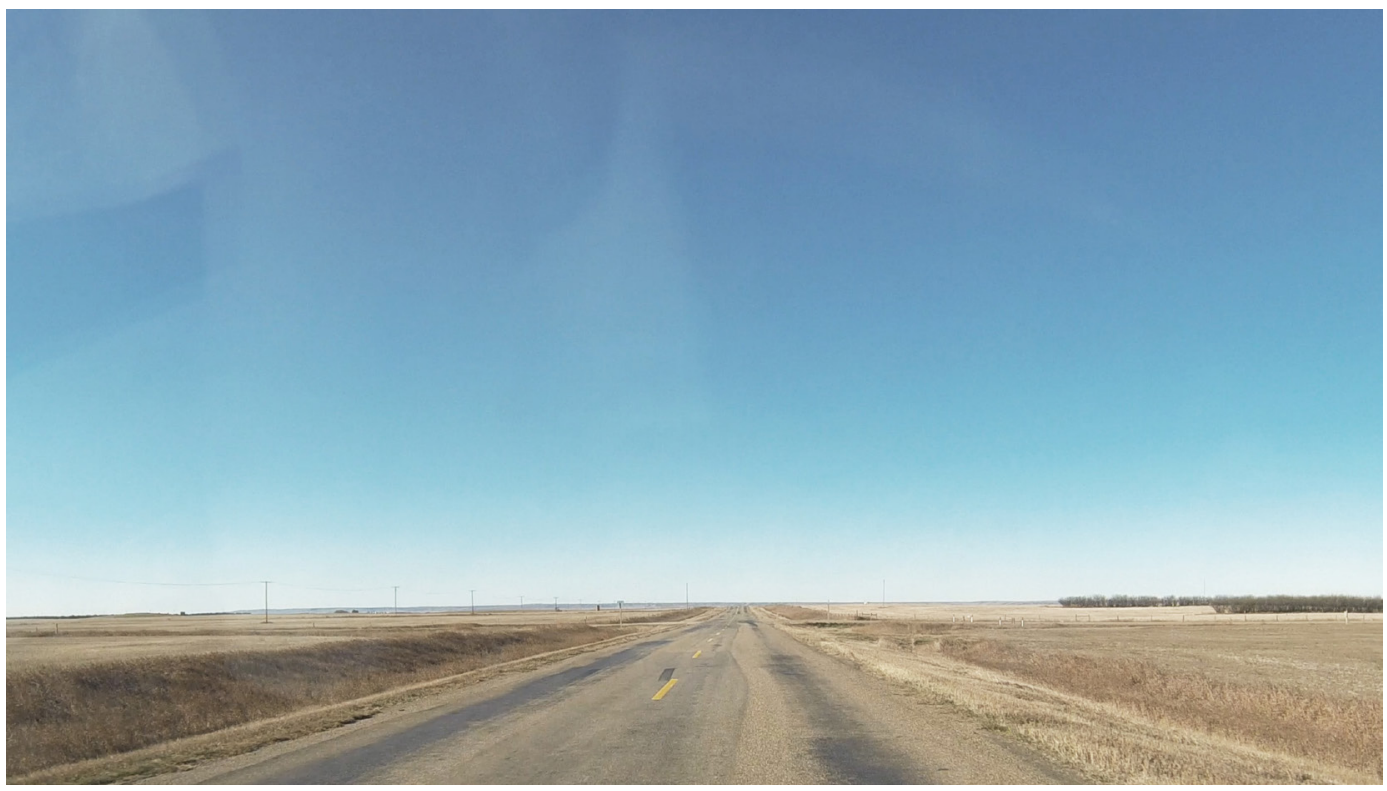

Fig 18.8 Minute 14 of Highway 13 Time-lapse. 


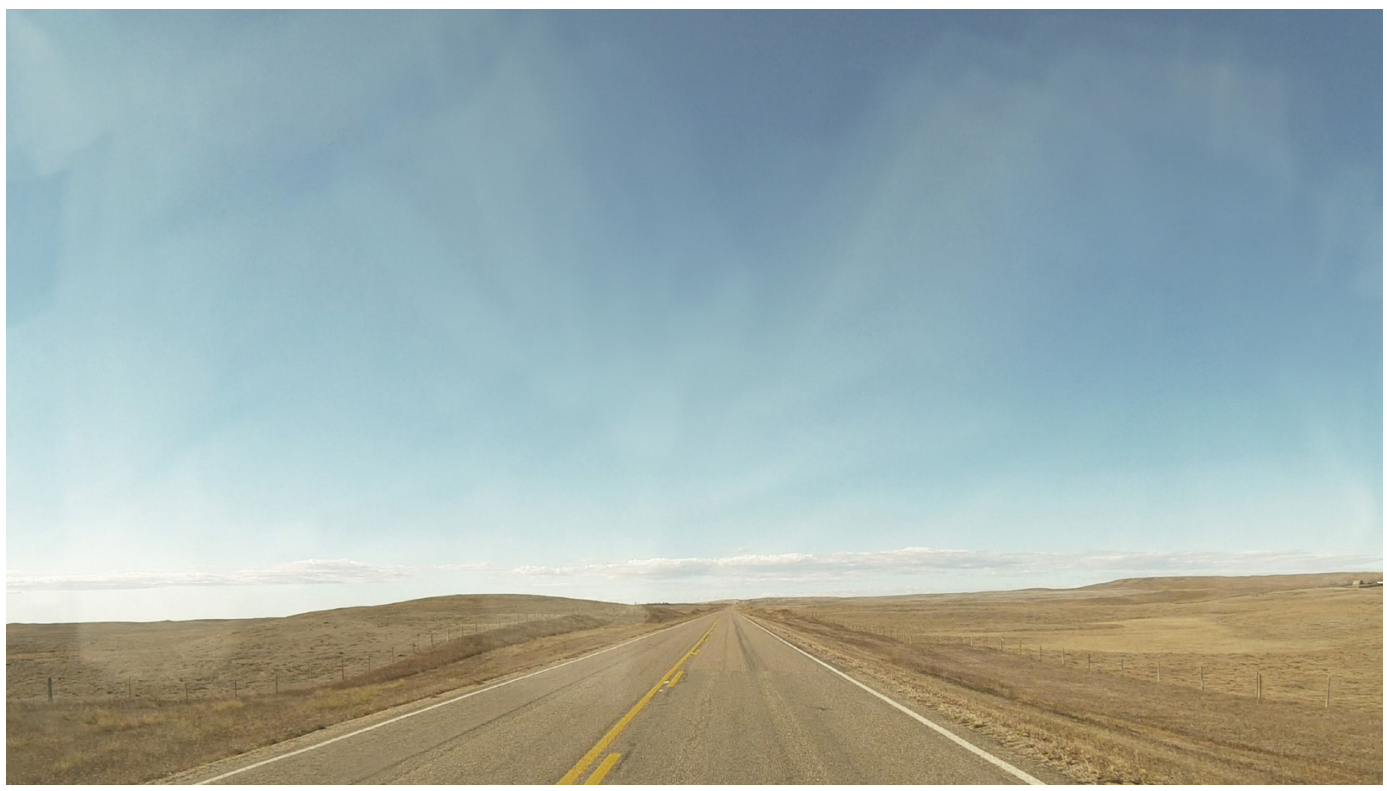

Fig 18.9 Minute 16 of Highway 13 Time-lapse. 

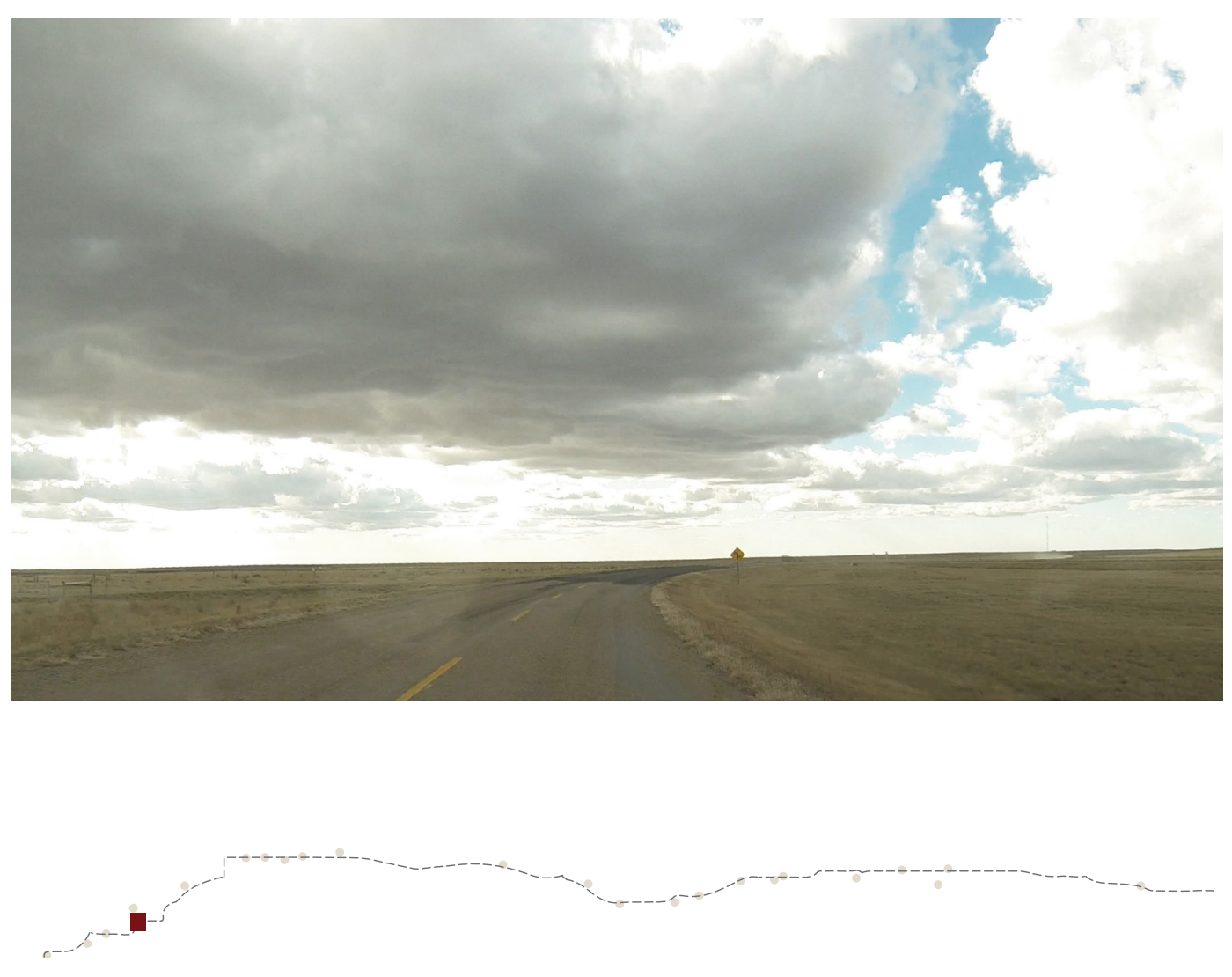

Fig 18.10 Minute 18 of Highway 13 Time-lapse. 

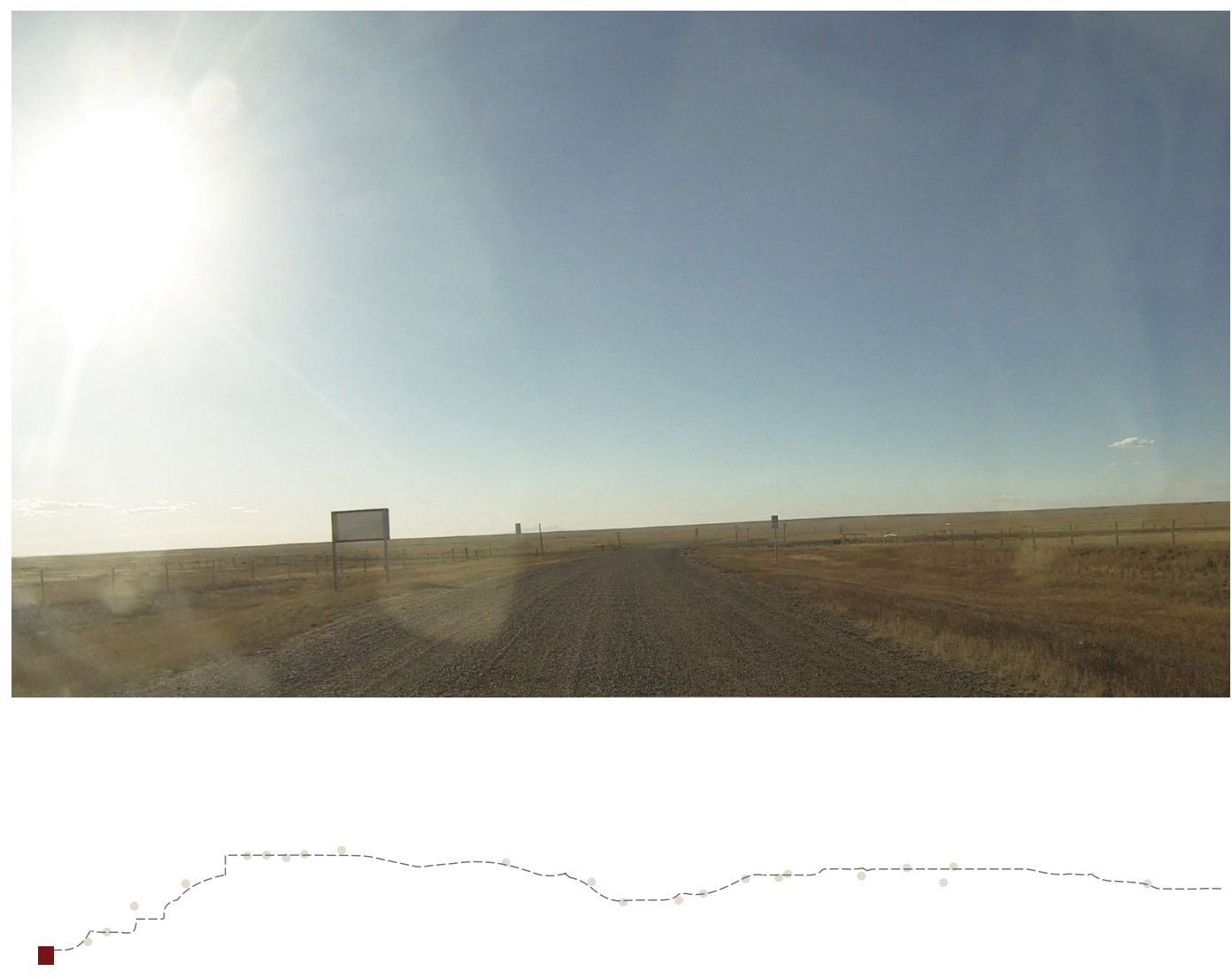

Fig 18.11 Minute 20 of Highway 13 Time-lapse. 


\section{Appendix 02 \\ Ghosted Ghost Towns}

Ghost Towns that are unable to be placed on Google Maps:

Bexhill

Brisbin

Chipperfield

Coothill

Court

Cummings

Diana

Dalesboro

DeckerVille

Edenburg

Elswick 
Floral

Gillespie

Graburn

Leofeld

Maxwellton

New Finland

New Warren

Penkill

Roncott

Rosemound

Surbiton

Taylorton

Thackeray

Valor

Vosnesenya 


\section{Conclusion}

Saskatchewan has a complex history many know little about. However, if one explores any one of the hundreds of abandoned towns within the province, they would find themselves engulfed by this hidden past and discover the many stories it holds. From the turn of the 20th century to the height of the mid-century, Saskatchewan endured a time of extensive changes. The early 1900's saw the province go from containing only a handful of towns and being a relatively unknown place, to encompassing several hundred new communities, due to mass immigration and settlement. Many of these settlements saw great prosperity for a time, and were thought to soon be the next grand centres of the continent. Only a couple decades later and this image was turned into something far less marvelous as intense drought, depression, and abrupt structural changes drove the economy to despair and brought the majority of the communities with it. By the 1950's over half of them had failed, and majority of the rest were soon to follow. Now, the number of abandoned towns nearly out weighs the ones who have maintained their establishment, and the number continues to grow.

Though Alberta and Manitoba border the province and share in some of this situation, Saskatchewan had far greater numbers when it came to settlement: the amount of rails, towns, and roads built to accommodate the mass immigration outweighed any other. Not only that, the province saw worse fall as the drought was more severe than anywhere else as well as the fact that the province nearly solely depended on the agricul- 
tural economy where as its bordering provinces had other resources to aid in keeping more of their towns afloat.

Saskatchewan's southern landscape is now filled with ghosts. Memories and emotions created from layers of history engraved in the surfaces that each town withholds, creating an atmosphere heavy with feeling and suffused with narrative. The presence of all that came before lingers over them, leaving the sites to feel alive though nothing living occupies their spaces. However, as time goes on, the traces of their past begins to fade - until they disappear entirely. As many have already succumbed to this fate, the collection of all that remains must be initiated.

Proposing a method in which this may follow, Saskatchewan's 'Ghost Town Catalogue' outlines a template for information and illustrations to be filled in - a number of towns have been curated accordingly. Each town's past and current conditions, along with their atmosphere, are represented through layered drawings, imagery, and personal anecdotes, suggesting to the reader some of the ghosts that exist within them.

Further forms of storytelling could later be built upon this as well; for instance, certain parts of a town's narrative could take shape in an exploration driven app. This could be developed by using the online map I have created to document the location of these hundreds of towns in the first place (fig. 2.1). Users could view the map and click on towns of interest and access the coordinates to take them to places rich with history, nearly invisible and otherwise unknown. Through using the individual's geo-location, upon reaching certain areas of a site and holding up their phone to view the site through their camera, a story is revealed with 
the past presenting itself over the camera's view.

Through following the template and the samples of collection and representation, a record of every town could be accomplished, resulting in a major piece of Saskatchewan's heritage being able to live on - even after most physical traces have dissolved. 


\section{Works Cited}

Avery, Cheryl, and Jene M. Porter. Perspectives of Saskatchewan. Winnipeg: Univ. of Manitoba Press, 2009.

Bachusky, Johnnie. Ghost Town Stories of the Red Coat Trail: From

Renegade to Ruin on the Canadian Prairies. Victoria, B.C.: Heritage House, 2010.

Bell, Michael Mayerfeld. "The Ghosts of Place." Theory and Society26, no. 6 (December 1997): 813-36. doi:10.1023/a:1006888230610.

Bohi, Charles W., and Leslie S. Kozma. "Interwar Rail Construction in Saskatchewan and Alberta: An Evaluation." Prairie Perspectives (October 2008): 45-68. Accessed November 18, 2018.

"Canada's Population Estimates." Statistics Canada: Canada's National Statistical Agency. December 19, 2007. Accessed November 28, 2018. https://www150.statcan.gc.ca/n1/daily-quotidien/071219/ dq071219b-eng.htm.

Dyck, Bruce. "Dirty Thirties: Fact and Myth." The Western Producer. July 28, 2005. Accessed January 8, 2019. https://www.producer. com/2005/07/dirty-thirties-fact-and-myth/.

Gruending, Dennis. The Middle of Nowhere: Rediscovering Saskatchewan. Saskatoon: Fifth House, 1996.

Hall, Heather, and Rose Olfert. "Saskatchewan." State of Rural Canada. Accessed March 26, 2019. http://sorc.crrf.ca/saskatchewan/. 
Hornstein, Shelley. Losing Site: Architecture, Memory and Place. Farnham: Ashgate, 2013.

Korsmeyer, Carolyn. "The Triumph of Time: Romanticism Redux." The Journal of Aesthetics and Art Criticism72, no. 4 (2014): 431-48. doi:10.1111/jaac.2014.72.issue-1.

Kudelik, Gail. "Red Coat Trail." The Canadian Encyclopedia. February 7, 2006. Accessed December 12, 2018. https://www.thecanadianencyclopedia.ca/en/article/red-coat-trail.

Mackay-Lyons, Brian. Ghost: Building an Architectural Vision. New York, NY: Princeton Architectural Press, 2008.

"Measuring Land in Saskatchewan." ISC. Accessed January 8, 2019. https://www.isc.ca/About/History/LandSurveys/MeasuringLandSask/ Pages/default.aspx.

Pletcher, Kenneth. "Trans-Canada Highway.” Encyclopædia Britannica. January 11, 2019. Accessed February 14, 2019. https://www.britannica.com/topic/Trans-Canada-Highway.

Struthers, James. "Great Depression." The Canadian Encyclopedia. July 11, 2013. Accessed January 6, 2019. https://www.thecanadianencyclopedia.ca/en/article/great-depression.

Thomas Spence. The Prairie Lands of Canada. Montreal, QC: Gazette Printing House, 1879.

Treib, Marc. Spatial Recall: Memory in Architecture and Landscape. New York: Routledge, 2009. 
Usiskin, Michael. Uncle Mike's Edenbridge: Memoirs of a Jewish Pioneer Farmer. Translated from the Yiddish by Marcia Usiskin Basman. Winnipeg: Peguis Publishers, 1983.

Canada. Railway Lands Branch. Department of the Interior. Supplement to Homestead Maps of Manitoba, Saskatchewan, and Northern and Southern Alberta. By W. J. Roche and W. W. Cory. 6.

WORKS CITED IN TOWN STORIES:

Bachusky, Johnnie. "Robsart." Saskatchewan Ghost Towns. Accessed November 21, 2018. http://www.ghosttownpix.com/sask/towns/robsart.html.

Doering, Chris, and Connie Biggart. "A Slice of Robsart." Off The Beaten Path - with Chris \& Connie. May 2014. Accessed March 30, 2019. https://www.bigdoer.com/20938/exploring-history/a-slice-of-robsart/.

Larson, Troy. "Vanishing Hamlet: Admiral, Saskatchewan." Ghosts of North America. February 21, 2018. Accessed October 25, 2018. http://www.ghostsofnorthamerica.com/admiral-saskatchewan/.

Wauchope/Parkman Historical Society. Precious Memories of Time: A Salute to the Pioneers of Wauchope and Parkman. Regina: Focus Pub., 1989.

Chabun, Will. "Photo Albums Document Life in a Small Saskatchewan Town That's Now Almost Disappeared." Regina Leader Post. September 14, 2016. Accessed February 28, 2019. https://leaderpost. $\mathrm{com} /$ news/local-news/a-melaval-mini-mystery. 


\section{IMAGE SOURCES:}

Chandler, Graham. "Selling the Prairie Good Life." Selling the Prairie Good Life - Canada's History. September 7, 2016. Accessed September 18, 2018. https://www.canadashistory.ca/explore/settlement-immigration/selling-the-prairie-good-life.

Lundeen, Glen. "Saskatchewan." Images of Prairie Towns. Accessed October 2018. http://www.prairie-towns.com/index.html.

Canada. Railway Lands Branch. Department of the Interior. Supplement to Homestead Maps of Manitoba, Saskatchewan, and Northern and Southern Alberta. By W. J. Roche and W. W. Cory. 6. 


\section{In the Presence of Ghosts}

Saskatchewan's Abandoned Landscape

by Gina Rehbein 